\title{
Def1 promotes polymerase exchange at stalled replication forks upon DNA damage
}

\author{
Doctoral thesis \\ (Ph.D. Dissertation)
}

Andreea Daraba

Supervisor: Dr. Ildikó Unk

Doctoral School of Biology of the Faculty of Science and Informatics University of Szeged

The Institute of Genetics

Biological Research Center of the Hungarian Academy of Sciences

2014

Szeged 


\section{Table of contents}

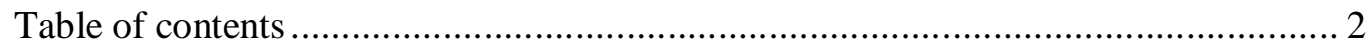

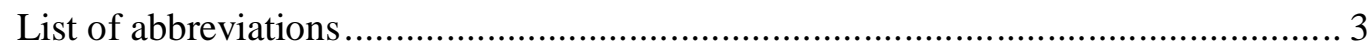

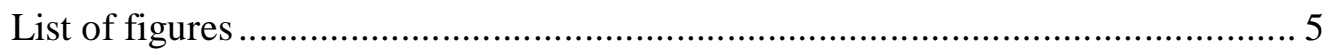

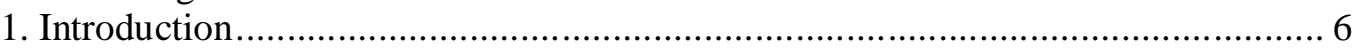

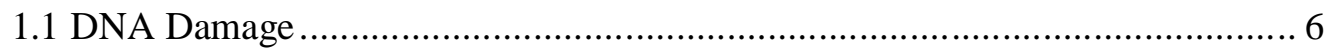

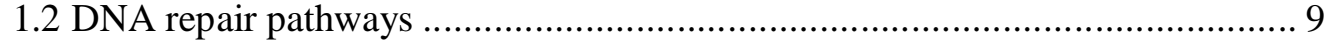

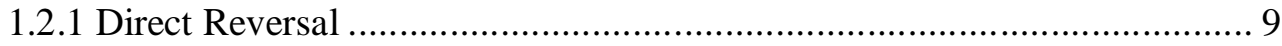

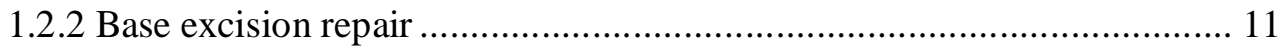

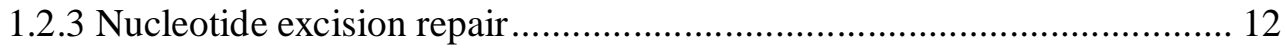

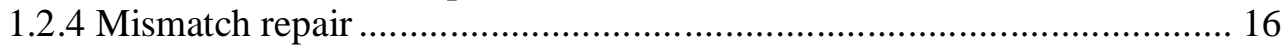

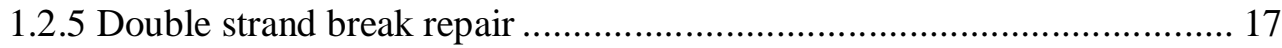

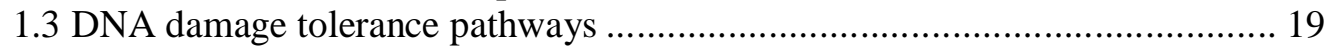

1.3.1 Rad52 dependent recombinational pathway..................................... 20

1.3.2 Rad6-Rad18 dependent DNA damage tolerance pathway ....................... 20

1.3.2.1 Error-free post replication repair.................................................. 21

1.3.2.2 Translesion synthesis: Rev1, Rev3, Rev7 and Rad30 _..................... 24

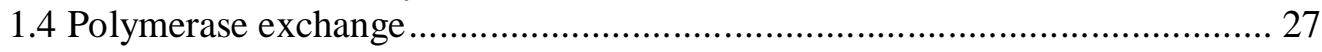

1.5 Ubiquitin and its role in proteasomal degradation and DNA damage bypass .. 29

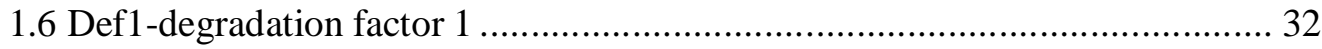

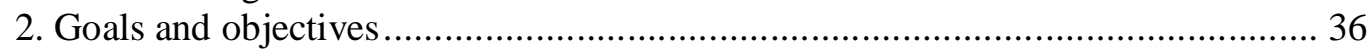

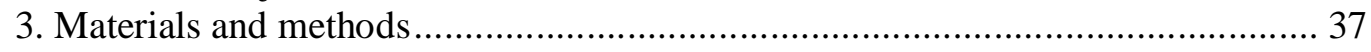

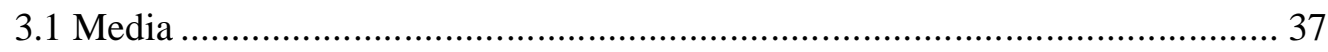

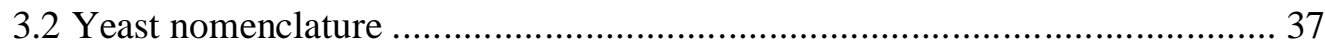

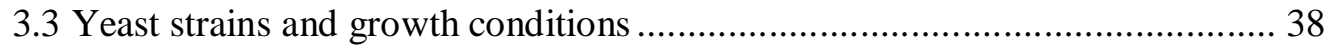

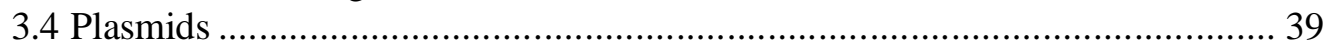

3.5 Generation of deletion strains by homology based gene replacement ............ 40

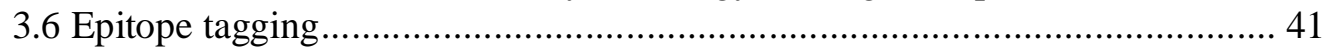

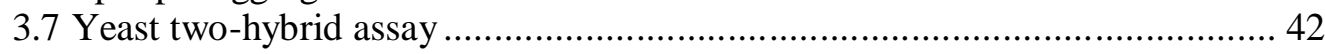

3.8 Quantitative assay of sensitivity to UV ............................................... 42

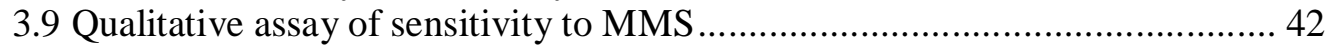

3.10 UV-induced mutagenesis ................................................................. 42

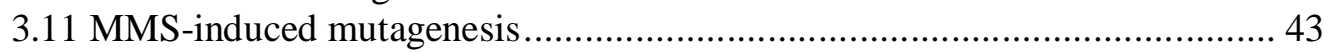

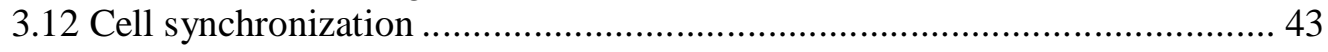

3.11 Protein tehniques- whole cell extract and western blotting ........................ 44

3.12 GST Fusion protein expression and pulldown assay ................................ 45

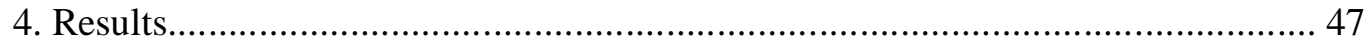

4.1 Genetic relations between $D E F 1$ and DNA damage tolerance genes ............. 47

4.2 Deletion of $D E F 1$ abolishes the UV and MMS-induced mutagenesis ............ 53

4.3 Yeast two hybrid assays fail to identify Def1 interaction partners .................. 55

4.4 Pol3 is degraded upon DNA damage by a Def1-dependent manner............... 56

4.5 Def1 induces the ubiquitination and proteasomal degradation of Pol3 ............ 60

4.6 Pol31 and Pol32 are not subject to UV-induced degradation ....................... 62

4.7 In vitro complex formation between Pol31, Pol32 and Rev1 ....................... 63

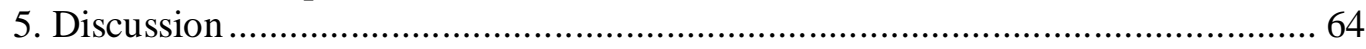

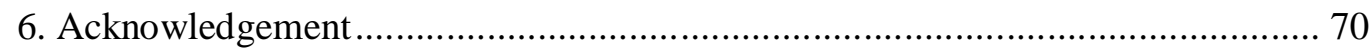

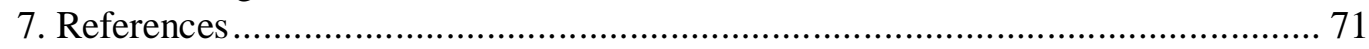

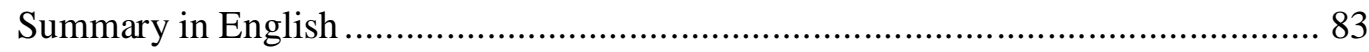

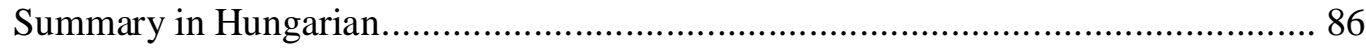




\section{List of abbreviations}

\begin{tabular}{|c|c|}
\hline AP site & Apurinic/Apyrimidinic site (also known as an abasic site) \\
\hline APF-1 & ATP-dependent Proteolysis Factor $\mathbf{1}$ \\
\hline ATP & Adenosine-5'-triphosphate \\
\hline BER & Base Excision Repair \\
\hline Chr IX & Chromosome IX \\
\hline $\mathrm{CS}$ & Cockayne Syndrome \\
\hline DDT & DNA Damage Tolerance \\
\hline DEF1 & RNAPII Degradation Factor 1 \\
\hline DNA & Deoxyribonucleic Acid \\
\hline DNA-PKcs & DNA-dependent Protein Kinase, catalytic subunit \\
\hline DSBs & Double-Strand Breaks \\
\hline DTT & Dithiothreitol \\
\hline E.coli & Escherichia coli \\
\hline E1 & Ubiquitin activating enzyme \\
\hline E2 & Ubiquitin conjugating enzyme \\
\hline E3 & Ubiquitin ligase enzyme \\
\hline EDTA & Ethylenediaminetetraacetic Acid \\
\hline EST & Ever Shorter Telomeres \\
\hline FOA & 5-Fluoroorotic Acid \\
\hline $\mathrm{g}$ & Gram \\
\hline GAL & Galactose \\
\hline GGR & Global Genom Repair \\
\hline GST & Glutathione S-Transferase \\
\hline HA & Hemagglutinin \\
\hline HLTF & Helicase Like Transcription Factor \\
\hline HNPCC & Hereditary Nonpolyposis Colorectal Carcinoma \\
\hline HR & Homologous Recombination \\
\hline $\mathrm{H}_{2} \mathrm{~S}$ & Hydrogen Sulfide \\
\hline IDLs & Insertion/Deletion Loops \\
\hline $\mathrm{kDa}$ & Kilodalton \\
\hline LIF1 & Ligase Interacting Factor 1 \\
\hline MALDI-TOF & Matrix-Assisted Laser Desorption/Ionization-Time-Of-Light \\
\hline MGMT & $\mathrm{O}^{6}$-methylguanine DNA methyltransferase \\
\hline $\min$. & Minute \\
\hline $\mathrm{ml}$ & Millilitre \\
\hline MMR & Mismatch Repair \\
\hline MMS & Methyl methanesulfonate \\
\hline Mms2 & Methyl methanesulfonate sensitivity protein $\mathbf{2}$ \\
\hline MQ water & Water purified with a Milli-Q water purification system \\
\hline MRE & Meiotic REcombination \\
\hline MS & Mass Spectrometry \\
\hline MSI & Microsatellite Instability \\
\hline NEJ1 & Nonhomologous End-Joining defective 1 \\
\hline NEM & N-ethylmaleimide \\
\hline NER & Nucleotide Excision Repair \\
\hline
\end{tabular}




\begin{tabular}{|l|l|}
\hline NHEJ & Non-Homologous End-Joining \\
\hline OD $_{600 n m}$ & Optical Density of 600 nanometers \\
\hline O $^{6}$-mG & O $^{6}$-methylguanine \\
\hline O/N & Overnight \\
\hline ONPG & O-nitrophenol- -D-galactopyranoside \\
\hline ORF & Open Reading Frame \\
\hline PBS & Phosphate Buffered Saline \\
\hline PCNA & Proliferating Cell Nuclear Antigen \\
\hline PEP 4 & Carboxypeptidase Y-deficient $\mathbf{4}$ \\
\hline PGK & Phosphoglycerate kinase \\
\hline POL & Polymerase \\
\hline PRB 1 & Proteinase B 1 \\
\hline PRR & Postreplication repair \\
\hline Rad & Radiation sensitive \\
\hline Rev & Reversionless \\
\hline RNA & Ribonucleic acid \\
\hline RNAPII & RNA Polymerase II \\
\hline RRM & rDNA Recombination Mutation \\
\hline SC-medium & Synthetic Complete medium \\
\hline SDS & Sodium Dodecyl Sulfate \\
\hline S phase & Cell cycle Synthetic phase \\
\hline SsDNA & Single-Stranded DNA \\
\hline SHPRH & SNF2, histone-linker, PHD and RING finger domain-containing helicase \\
\hline SWI/SNF & SWItch/Sucrose NonFermentable \\
\hline TCA & Trichloroacetic acid \\
\hline TCR & Transcription Coupled Repair \\
\hline TLS & Translesion Synthesis \\
\hline Ub & Ubiquitin \\
\hline Uba1 & Ubiquitin Activating enzyme E1 \\
\hline Ubc & Ubiquitin Carrier \\
\hline UV & Ultraviolet light \\
\hline WB & Western Blott \\
\hline XP-V & Xeroderma Pigmentosum Variant \\
\hline XRCC & X-ray Repair Cross Complementing \\
\hline XRS & X-ray Sensitive \\
\hline YPD & Yeast extract, Peptone and D-glucose medium \\
\hline
\end{tabular}




\section{List of figures}

Figure 1 DNA damage response

Figure 2 Direct reversal of T-Tdimers.

Figure 3 The base excision repair pathway

Figure 4 Main repair systems in Saccharomyces cerevisiae

Figure 5 Nucleotide excision repair

Figure 6 The mismatch repair pathway in E. coli

Figure 7 The pathways of DSB repair

Figure 8 The $R A D 6-R A D 18$ dependent damage tolerance pathway

Figure 9 Domain architecture and functions of Rad5 and its putative orthologs

SHPRH and HLTF

Figure 10 DNA damage tolerance pathway

Figure 11 The Ubiquitin system

Figure 12 Schematic diagram of a principle of gene targeting

Figure 13 Genetic analysis of $D E F 1$ with mutants of different branches of the RAD6 pathway upon UV-irradiation

Figure 14 Genetic analysis of $D E F 1$ with mutants of the different branches of the $R A D 6$ pathway upon MMS treatment

Figure 15 Genetic interactions of $R A D 30$ with $M M S 2$ and $R E V 3$ mutants upon MMS treatment

Figure 16 DNA damage-induced mutagenesis in different mutants

Figure $17 \mathrm{UV}$-induced mutagenesis is abolished in defl deletion mutants

Figure 18 MMS-induced mutagenesis in defl strain is abolished.

Figure 19 The effect of increasing UV doses on the level of Pol3

Figure 20 UV Induced degradation of Pol3 in different mutants

Figure 21 Pol3 UV-induced degradation is mediated by the proteasome

Figure 22 Def1 assists Pol3 poly-ubiquitination

Figure 23 Pol31 and Pol32 are not affected by UV-induced degradation

Figure 24 Rev1 forms a complex with Pol31 and Pol32

Figure $25 D E F 1$ in the RAD6-RAD18 dependent damage tolerance pathway

Figure 26 Model for polymerase exchange at a DNA damage site 


\section{Introduction}

\subsection{DNA Damage}

The publication of Watson and Crick's famous paper titled „Molecular Structure of Nucleic Acids: A Structure for Deoxyribose Nucleic Acid" marked the dawn of a new scientific era, the age of molecular biology. As these authors drew to a close, their brief but far-reaching description of the DNA double helix, they pointedly commented, "It has not escaped our notice that the specific [base] pairing we have postulated immediately suggests a possible copying mechanism for the genetic material" [1]. The mechanism for DNA replication that Watson and Crick viewed as intuitively obvious is strand separation followed by the copying of each strand. In the process, each separated strand acts as a template for the synthesis of a new complementary strand whose nucleotide sequence is fixed by the base-pairing rules Watson and Crick proposed. Previously it was postulated that during evolution DNA has been selected as a major carrier of genetic information due to its relative stability over other macromolecules such as RNA, however it is by no means inert. The reactivity of DNA with endogenous or environmental agents results in chemical modifications, which can have mutagenic or lethal effect upon replication [2]. Damage to DNA is unavoidable and arises in many ways. It is estimated that in a single human cell the number of DNA damage events range from $10^{4}$ to $10^{6}$ per day [3]. DNA damage (Fig.1) can be caused by spontaneous cleavage of chemical bonds in DNA, by environmental agents such as ultraviolet radiation from sunlight and cigarette smoke [4] or exposure to therapeutic agents used in the treatment of cancers including chemotherapeutic drugs and ionising radiotherapy [5]. DNA damage can be also caused by reaction with genotoxic chemicals, like reactive oxygen species (ROS), that are by-products of normal cellular metabolism or occur in the environment [6]. ROS can cause oxidative damage to DNA leading to single-and double-strand breaks (SSBs and DSBs) [7].

A change in the normal DNA sequence, called a mutation, can occur during replication when a DNA polymerase inserts a wrong nucleotide as it reads a damaged template. Mutations also occur at a low frequency as the result of copying errors introduced by DNA polymerases when they replicate an undamaged template. If mutations were left uncorrected, cells might accumulate too many mutations that can 
have detrimental effects on genetic stability. Failure to repair DNA lesions may result in blockages of transcription and replication, mutagenesis, and/or cytotoxicity [3]. In addition, the DNA in germ cells might incur too many mutations for viable offspring to be formed. In humans DNA damage induced alterations have been shown to be involved in a variety of genetically inherited disorders, in aging [8], and in carcinogenesis $[9,10]$.

Thus the prevention of DNA sequence errors in all types of cells is important for survival, and several cellular mechanisms for repairing damaged DNA and correcting sequence errors have evolved. Prokaryotic and eukaryotic cells encode multiple repair systems that can deal with the damage $[3,11]$. Although cells are equipped with repair mechanisms, they are not always able to clear the DNA template of all damage ahead of a replication fork. The different types of DNA damage and obstacles on the template will lead to different consequences if met by a replication fork [12].

The DNA damage response (DDR) is the name given to the network of coordinated, highly regulated signalling pathways that monitor and protect the integrity of the genome [12]. DDR involves numerous proteins which detect DNA lesions and transduce signals to downstream effector proteins that determine the response to resolve the induced DNA damage [13]. Upon sensing DNA damage or stalls in replication (Fig.1), cell cycle checkpoints are activated to arrest cell cycle progression to allow time for repair before the damage is passed on to daughter cells. In addition to checkpoint activation, the DNA damage response leads to induction of transcriptional programs, enhancement of DNA repair pathways, and when the level of damage is too severe to repair to initiation of apoptosis [13]. All of these processes are carefully coordinated so that the genetic material is faithfully maintained, duplicated, and segregated within the cell. Signalling in the DDR is mediated in large part through the post-translational modification of downstream effector proteins, which leads to the recruitment of a plethora of proteins to the sites of damage. Posttranslational modifications include phosphorylation, ubiquitination, SUMOylation, glycosylation, ADP-ribosylation, and methylation [14]. 


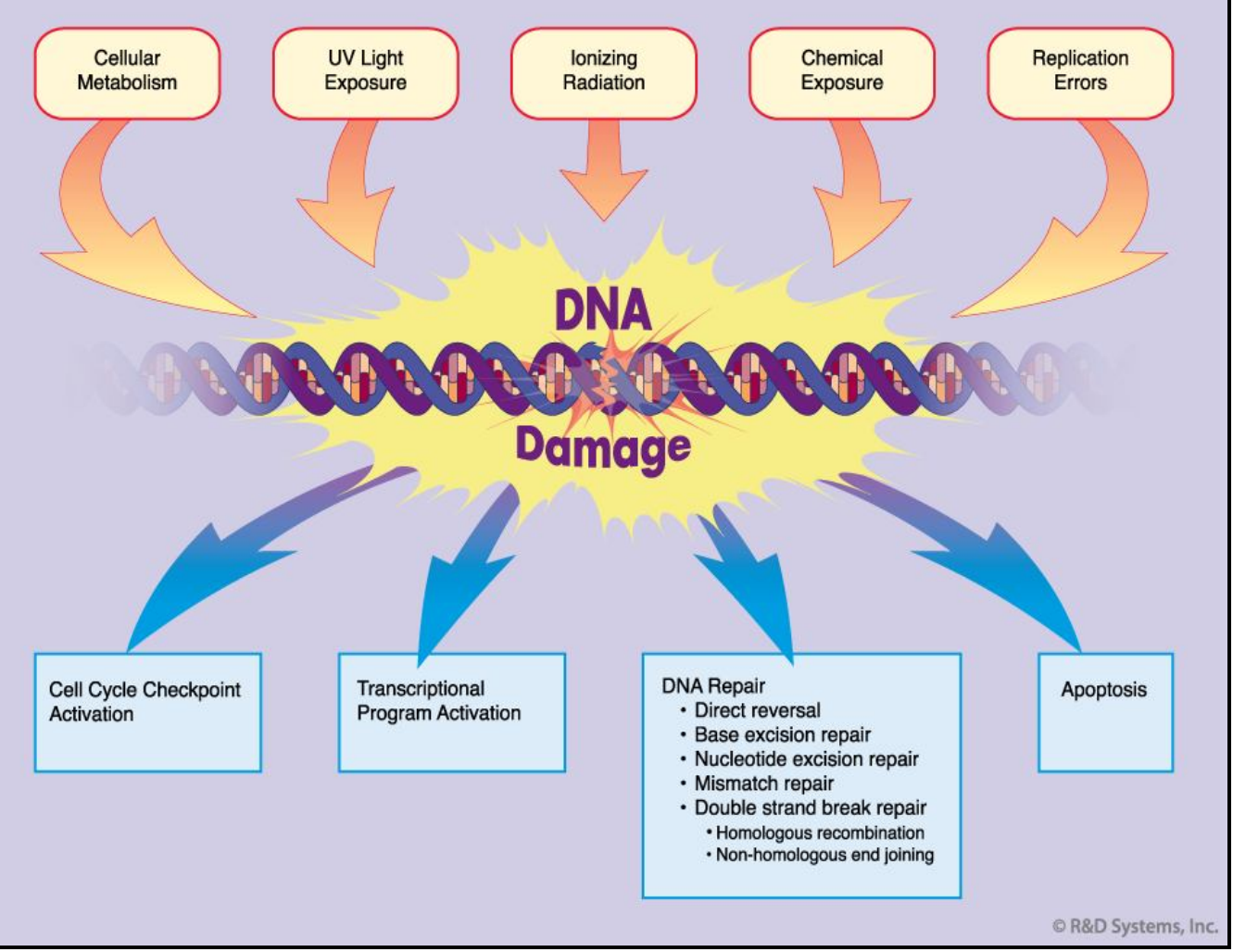

Figure 1 DNA damage response

DNA damanage is caused by a variety of sources. The cellular response to damage may involve activation of cell cycle checkpoint, commencement of transcriptional programs, execution of DNA repair, or when the damage is severe, initiation of apoptosis. (R\&D Systems, Inc)

Significantly, defects in DNA repair mechanisms and cancer are closely related. When repair mechanisms are compromised, mutations accumulate in the cell's DNA. If these mutations affect genes that are normally involved in the careful regulation of cell division, cells can begin to divide uncontrollably, leading to tumor formation, and cancer [9].

With so many types of DNA lesions occurring at such a high frequency, multiple responses to DNA damage have evolved. These processes can be divided into two main categories: DNA repair and DNA damage tolerance. DNA repair is a cellular response to DNA damage that results in the restoration of the original nucleotide sequence and DNA structure. If -by any means- the DNA repair pathways are unable to repair lesions prior to the onset of $S$ phase that can result in the breakage of the replication fork leading to recombination, chromosomal rearrangements and finally cell death. To prevent cell death in such circumstances, all cells are able to 
activate DNA damage tolerance pathways. DNA damage tolerance acts to reinitiate replication in the presence of damage but without lesion removal.

\subsection{DNA repair pathways}

Eukaryotic and prokaryotic cells possess multiple mechanisms to repair DNA and control damage to their genomes. These include direct reversal, base excision repair (BER) and nucleotide excision repair (NER) that excise and replace damaged bases and helix-distorting lesions, respectively. In addition, mismatch repair (MMR) proteins act to replace mismatched nucleotides and repair insertion/deletion loops. Furthermore, there are two types of double-stranded DNA break repair, homologous recombination (HR) and non-homologous end-joining (NHEJ).

\subsubsection{Direct Reversal}

Cells are known to eliminate three types of damage to their DNA by chemically reversing it. These mechanisms do not require a template, since the types of damage they counteract can occur in only one of the four bases. Such direct reversal mechanisms are specific to the type of damage incurred and do not involve breakage of the phosphodiester backbone. Only a few types of DNA damage are repaired in this way, particularly pyrimidine dimers, alkylated guanine residues that have been modified by the addition of methyl or ethyl groups at the $\mathrm{O}^{6}$ position of the purine ring and methylated adenine and cytosine bases.

The formation of pyrimidine dimers upon irradiation with UV light results in an abnormal covalent bond between adjacent pyrimidine bases (Fig.2). The photoreactivation process reverses this damage by the action of a photolyase. This enzyme is activated by the energy absorbed fromblue/UV light (300-500nm wavelenght) [15]. Photolyase is a phylogenetically old enzyme present and functional in many species from bacteria to animals [16]. However, in humans and other placental mammals this photolyase activity is missing and its function is replaced by the less efficient nucleotide excision repair mechanism [17]. 


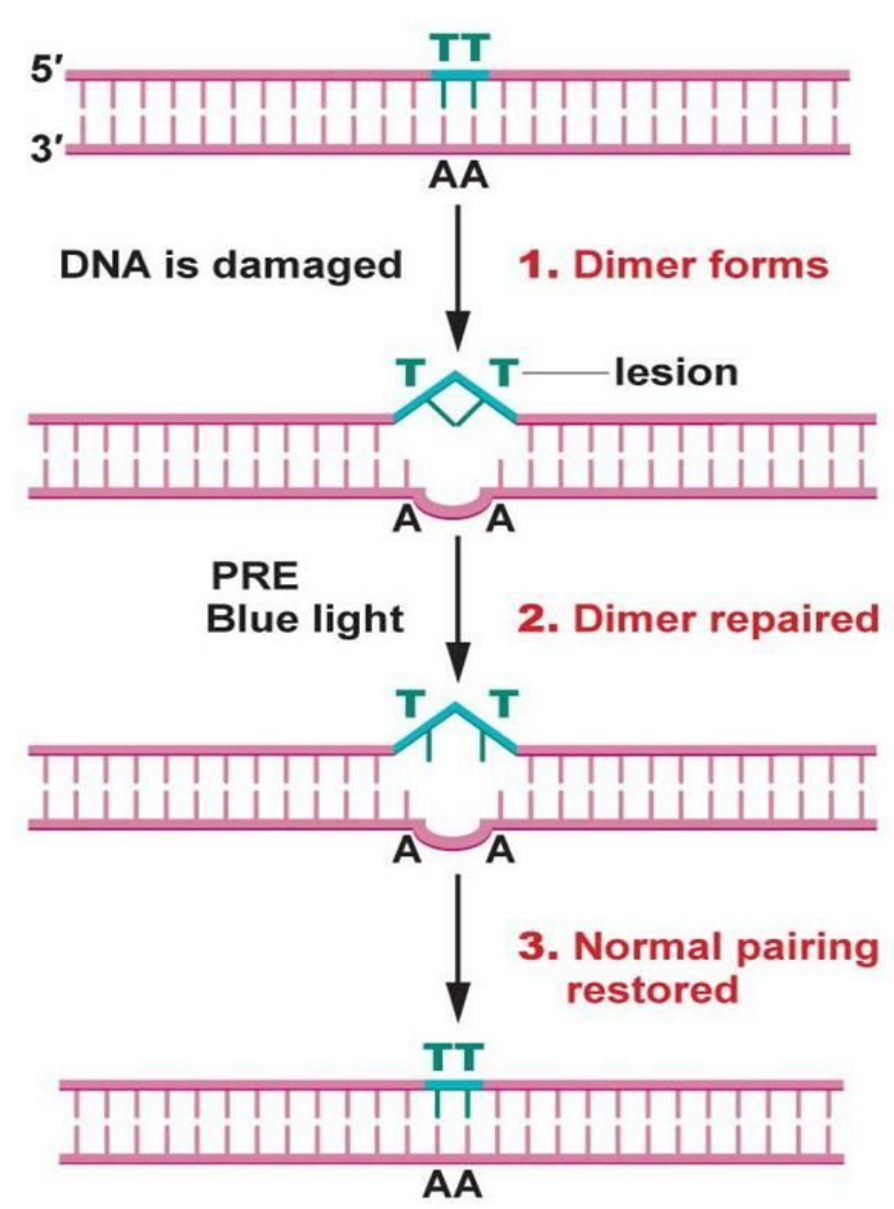

Figure 2 Direct reversal of $\mathbf{T}$-Tdimers.

Upon UV irradiation an abnormal covalent bond is formed between adjacent pyrimidine bases. The photoreactivation process reverses this damage by the action of a photolyase enzyme, activated by the energy absorbed from blue light.

http://www.studyblue.com/notes/note/n/chapter-14/deck/1327947

Another type of damage methylation of guanine bases [18] is directly reversed by the protein methyl guanine methyl transferase (MGMT) [19]. This is an expensive process because each MGMT molecule can be used only once; that is, the reaction is stoichiometric rather than catalytic. The inactivated alkyl-MGMT protein is then degraded in an ATP-dependent ubiquitin proteolytic pathway [20]. This energetically expensive repair mechanism for the correction of a relatively simple alkyl-adduct, $\mathrm{O}^{6}$ $\mathrm{mG}$, is extremely detrimental to the cell. Accordingly, a number of chemotherapeutic agents that attack the $\mathrm{O}^{6}$ position of guanine have been developed and are in clinical use [20]. 
1-methyladenine and 3-methylcytosine are repaired by oxidative demethylation catalyzed by a dioxygenase enzyme. This reaction occurs on both single and double-stranded DNA, with strong preference for double- stranded DNA and requires molecular oxygen, alpha-ketoglutarate and iron to oxidize the offending methyl group [21]. Direct reversal of methylated adenine and cytosine is important because failure to repair 1-methyladenine and 3-methylcytosine can lead to cell death in both E. coli [22] and human cells [23].

Although it might seem that direct reversal of damage would be the simplest way to correct the damage, in most cases the reverse reaction is not possible for thermodynamic or kinetic reasons. In a few cases, the reaction is reversible. Taking in consideration the vast variety of DNA lesions, cells have developed specialised repair mechanisms that can deal with several types of DNA damage.

\subsubsection{Base excision repair}

Base excision repair, a critical machinery which corrects DNA lesions and ensures that mutations are not propagated is a multi-step process that corrects nonbulky damage to bases resulting from oxidation, methylation, deamination, or spontaneous loss of the DNA base itself [24]. These alterations, although simple in nature, are highly mutagenic and therefore represent a significant threat to genome fidelity and stability [25]. The process of base excision repair is carried out by specific and sequential enzyme activities (Fig.3). Damaged bases are first identified and removed by DNA glycosylases, which break beta-N glycosidic bonds to create an abasic (AP) site. Depending on the initial events of base removal, repair proceeds through either the short patch (1 nucleotide) or long patch (2-10 nucleotides) repair pathways. This involves the AP site being recognized by an endonuclease, which nicks the damaged DNA, hydrolyzes the phosphodiester backbone 5' to the AP site, leaving a 3'-hydroxyl group and recruits DNA polymerases to fill the gap in the DNA. Finally, base excision repair is complete when the new DNA strand is sealed by DNA ligase [24]. 


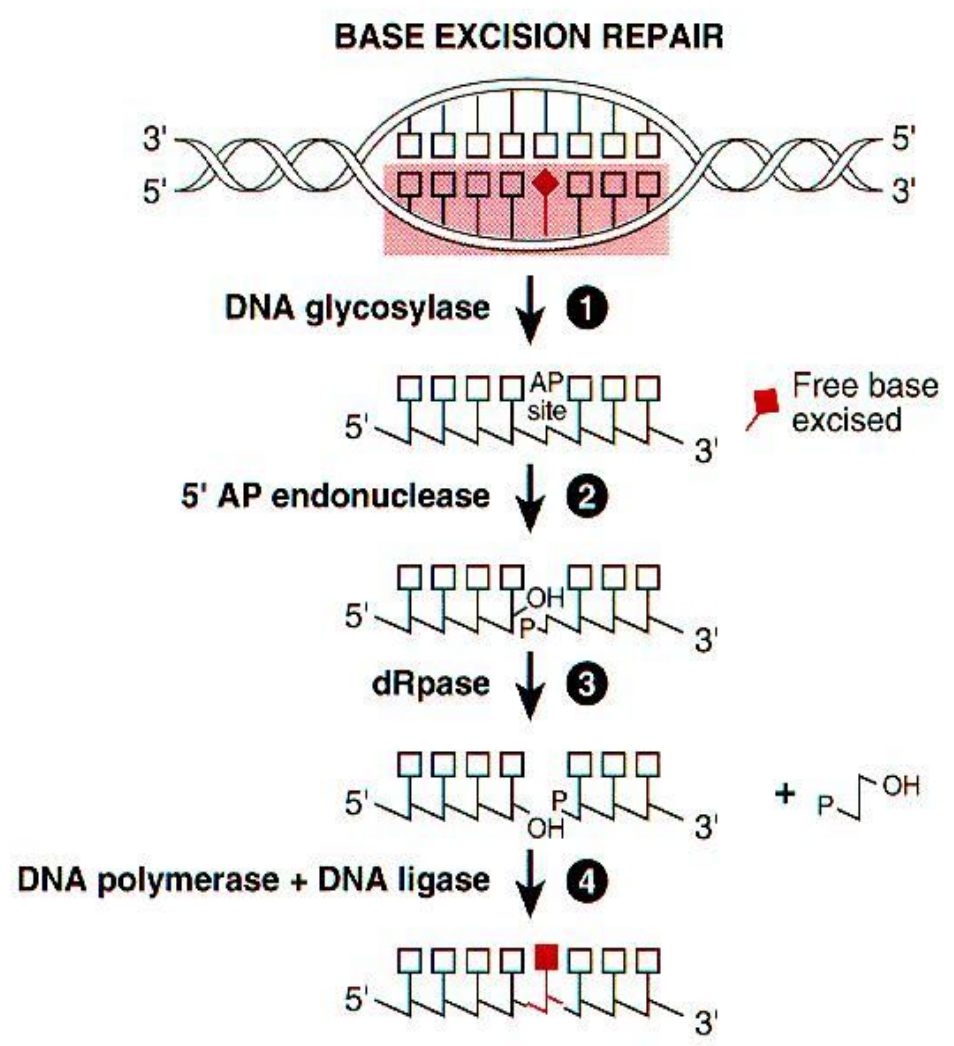

Figure 3 The base excision repair pathway

BER is initiated by a DNA glycosylase, which excises the damaged base to generate an abasic site for subsequent processing. The AP endonuclease incises the abasic site to yield a $3{ }^{\prime} \mathrm{OH}$. DNA polymerase replicates DNA from the 3'OH, generating a nick ready for subsequent ligation by DNA ligase.

http://jonlieffmd.com/blog/the-many-ways-neurons-repair-their-own-dna

\subsubsection{Nucleotide excision repair}

Nucleotide excision repair is perhaps the most flexible member of the DNA repair pathways considering the diversity of DNA lesions it acts upon. The most significant of these lesions are pyrimidine dimers, other NER substrates include bulky chemical adducts, DNA intrastrand crosslinks, and some forms of oxidative damage. The common features of lesions recognized by the NER pathway are that they cause both a helical distortion of the DNA duplex and a modification of the DNA chemistry [26].

This is a very precise process where only the defected strand is removed without affecting the undamaged DNA strand because that serves as the template for the 
modification and repairing process. The NER proteins are assembled in a way that allows for the verification of the damaged site before the actual removal of the DNA backbone [27]. When a distortion (like pyrimidine dimer) is recognized a 12 nucleotide segment containing the damage is excised, which generates a short DNA gap. This gap is subsequently filled in by DNA polymerase and finally, DNA ligase seals the ends [28]. The difference between BER and NER is that BER has the ability to detect and remove single nucleotides with the smallest modification such as the addition of one single methyl group. Thus, it is extremely efficient in fixing distorted DNA strands [27].

In yeast (Fig. 4), the proteins involved in removing the damaged nucleotides are named RadXX ("RAD” stands for "radiation sensitive") [29]. Damage recognition and incision of DNA during nucleotide excision repair in yeast [28] and mammalian cells $[30,31]$ requires multiple gene products. Amino-acid sequence homology between several yeast and mammalian genes suggests that the mechanism of nucleotide excision repair is conserved in eukaryotes [32].

\begin{tabular}{|c|c|c|}
\hline $\begin{array}{c}R A D 3 \\
\text { (Nucleotide Excision } \\
\text { Repair) }\end{array}$ & $\begin{array}{c}R A D 52 \\
\text { (Homologous } \\
\text { Recombination) }\end{array}$ & $\begin{array}{c}R A D 6 \\
\text { (Damage Bypass) }\end{array}$ \\
\hline $\begin{array}{l}\text { RAD1 } \\
R A D 2 \\
R A D 3 \\
R A D 4 \\
R A D 7 \\
R A D 10 \\
R A D 14 \\
R A D 16 \\
R A D 23\end{array}$ & $\begin{array}{l}\text { RAD50 } \\
\text { RAD51 } \\
\text { RAD52 } \\
\text { RAD53 } \\
\text { RAD54 } \\
\text { RAD55 } \\
\text { RAD56 } \\
\text { RAD57 } \\
\text { RAD59 }\end{array}$ & $\begin{array}{c}\text { RAD5 } \\
\text { RAD6 } \\
\text { RADI8 } \\
\text { RAD30 } \\
R E V 1 \\
R E V 3 \\
R E V 7 \\
M M S 2 \\
U B C 13 \\
P O L \delta \\
P C N A \\
\text { SRS2 }\end{array}$ \\
\hline
\end{tabular}

Figure 4 Main repair systems in Saccharomyces cerevisiae

Yeast mutants sensitive to UV or ionizing radiation are classified in three "epistasis" groups that are important for cell survival. The major genes in these three groups are listed above.

http://www.acsu.buffalo.edu/ kowalsk/dnarepair/bypass.html 
Considerable insight into the process of human NER has been gained through the study of two rare, autosomal recessive, but heterogeneous disorders - xeroderma pigmentosum (XP) [33] and Cockayne Syndrome (CS) [32] an extreme form of accelerated aging that is fatal early in life. The XP gene products are now known to perform various functions during NER, like damage recognition and DNA incision. The CS gene products, on the other hand, are required for NER-based repair of transcriptionally active genes [34].

Transcription-coupled repair (TCR) [35] is responsible for the fact that damage from the active strand of transcribed genes is more rapidly removed than those located on the non-transcribed genomic DNA [36]. The transcribed DNA strand is preferentially repaired compared with non-transcribed DNA strand in expressed genes because the stalled RNA polymerase II is the signal for recruitment of TCR factors (CSA and CSB proteins in humans and Rad26 and Rpb9 in yeast) (Fig.5). Following detection, the transcription factor II H (TFIIH) complex is recruited, and unwinds a stretch of approximately 30 nucleotides around the damage, providing access for other repair factors like endonucleases, which subsequently incise the DNA around the damage. After excision of the damaged strand, the resulting gap of 25 to 29 nucleotides is filled in by DNA synthesis and ligation [37].

Global genome repair (GGR) removes damage existing elsewhere in the genome [36]. GGR is initiated by UV-DDB ubiquitin ligase complex in humans. In yeast $\operatorname{Rad} 7$ and Rad16 form a complex that binds specifically to UV-damaged DNA in an ATP dependent manner (Guzder et al, 1997) (Fig.5). GGR utilizes specific proteins for the recognition of the damage, which constantly scan the genome for the presence of DNA damage. Except for the way of damage recognition, TCR and GGR share the same enzimatic pathway. 


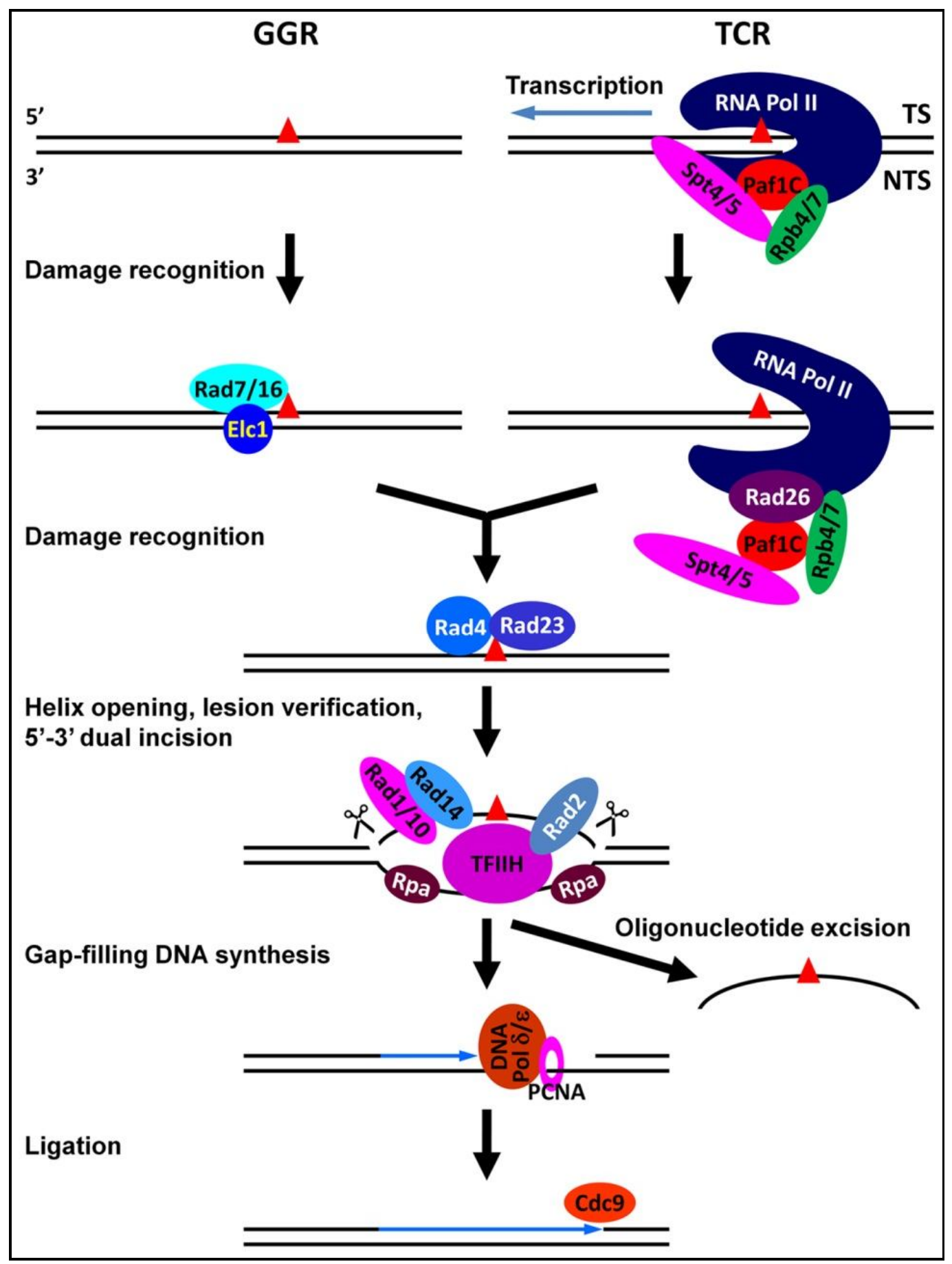

Figure 5 Nucleotide excision repair

NER is executed by two different damage-detection mechanisms, which utilize the same machinery to excise and repair the damage (Tatum D. and Shisheng Li, 2011, DNA Repair-On the Pathways to Fixing DNA Damage and Errors, Chapter6) 


\subsubsection{Mismatch repair}

The DNA mismatch repair pathway plays an essential role in the correction of replication errors such as base-base mismatches and insertion/deletion loops (IDLs) that result from DNA polymerase misincorporation of nucleotides and template slippage, respectively. Mispairs generated by the spontaneous deamination of 5methylcytosine and heteroduplexes formed following genetic recombination are also corrected via MMR. [38].

The overall process of MMR is similar to the other excision repair pathways. The DNA lesion (mismatch or IDL) is recognized (Fig. 6) and a patch containing the lesion is excised. The strand is corrected by a DNA polymerase and religated [39].

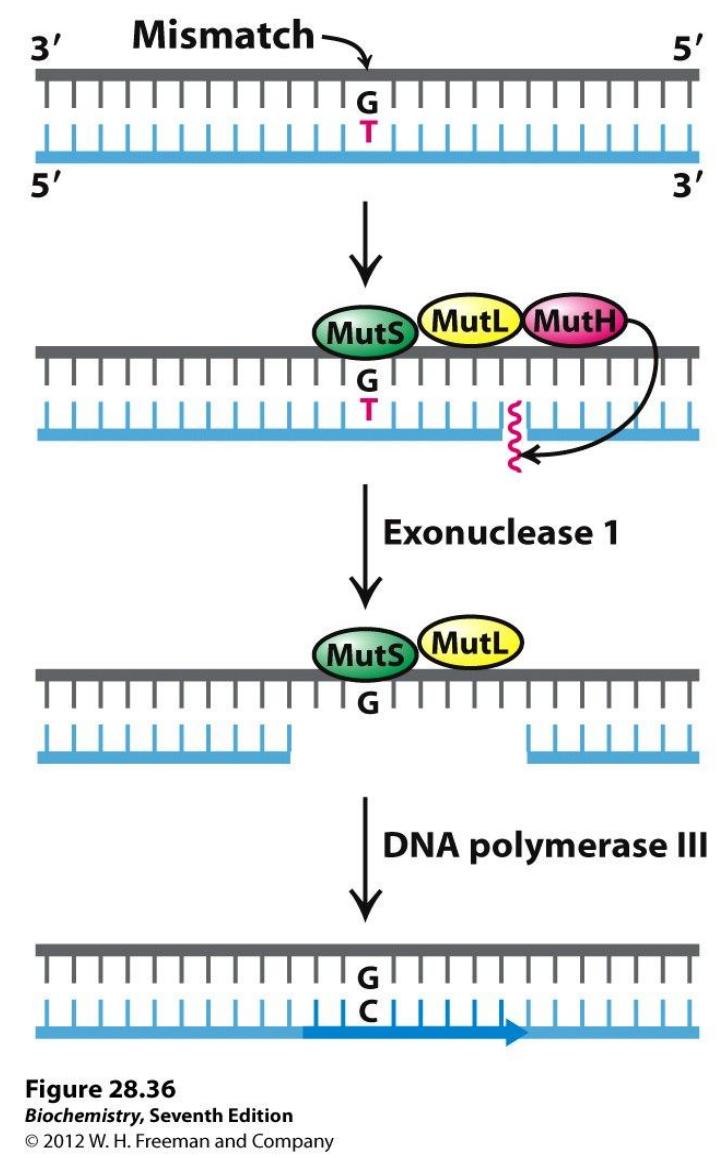

Figure 6 The mismatch repair pathway in $E$. coli

MMR is initiated by the recognition of mismatches by the MutS homodimer followed by recruitment of the MutL and MutH, which nick the DNA. This serves as an entry point for exonuclease 1 that removes a segment of DNA. This is subsequently filled in by DNA polymerase III and ligated to complete repair. (Biochemistry, Seventh Edition, 2012, W. H. Freeman et al.) 
In E.coli a number of genes were identified that, when mutationally inactivated, cause hypermutable strains. This so-called "mutator" cellular phenotype is characterized by elevated frequencies in spontaneous mutations and increased microsatellite instability [38]. The gene products are therefore called the "Mut" proteins, and are the major active components of the mismatch repair system. Three of these proteins are essential in detecting the mismatch and directing repair machinery to it: MutS, MutH and MutL [39]. Homologs of MutS and MutL have been identified in yeast, mammals, and other eukaryotes.

Mutations in several human MMR genes cause a predisposition to hereditary nonpolyposis colorectal carcinoma (HNPCC) [40], as well as a variety of sporadic tumors that display MSI [41].

\subsubsection{Double strand break repair}

Double strand breaks (DSBs) are perhaps the most severe form of DNA damage because they pose multiple problems for transcription, replication, and chromosome segregation. Damage of this type is caused by exogenous agents such as ionizing radiation and certain genotoxic chemicals. It may also originate from endogenous sources such as replication of single-stranded DNA breaks, endogenously generated reactive oxygen species, and mechanical stress on the chromosomes [42, 43]. DSBs differ from other types of DNA lesions in that they affect both strands of the DNA duplex and therefore prevent use of the complementary strand as a template for repair (see BER, NER, and MMR). Failure to repair these defects can result in chromosomal instabilities, which leads to dysregulated gene expression and carcinogenesis [9]. To counteract the detrimental effects of these potent lesions, cells have evolved two distinct pathways of DSB repair, homologous recombination (HR) and non-homologous end joining (NHEJ) [44]. The cellular decision as to which pathway to utilize for DSB repair is unclear, however, it appears to be largely influenced by stage within the cell cycle at the time of damage acquisition [42].

Homologous recombination directed repair corrects DSB defects in an errorfree manner using a mechanism that retrieves genetic information from a homologous, undamaged DNA molecule. The majority of HR-based repair takes place in late Sand G2-phases of the cell cycle when an undamaged sister chromatid is available for use as repair template (Fig.7). The Rad52 epistasis group of proteins (Fig 4), including Rad50, Rad51, Rad52, Rad53, Rad54, Rad55, Rad56, Rad57, Rad59 and 
Mre11 mediate this process [45]. The Rad52 protein itself is thought to be the initial sensor of the broken DNA ends. Processing of the damaged ends results in the production of 3' single-stranded DNA (ssDNA) overhangs. The newly generated ssDNA ends are bound by Rad51 to form a nucleoprotein filament [46]. The Rad51 nucleoprotein filament then searches the undamaged DNA on the sister chromatid for a homologous repair template [47]. Once the homologous DNA has been identified, the damaged DNA strand invades the undamaged DNA duplex in a process referred to as DNA strand invasion. A DNA polymerase then extends the 3 ' end of the invading strand and subsequent ligation by DNA Ligase I yields a heteroduplexed DNA structure. This recombination intermediate is resolved and the precise, error-free correction of the DSB is complete [42].

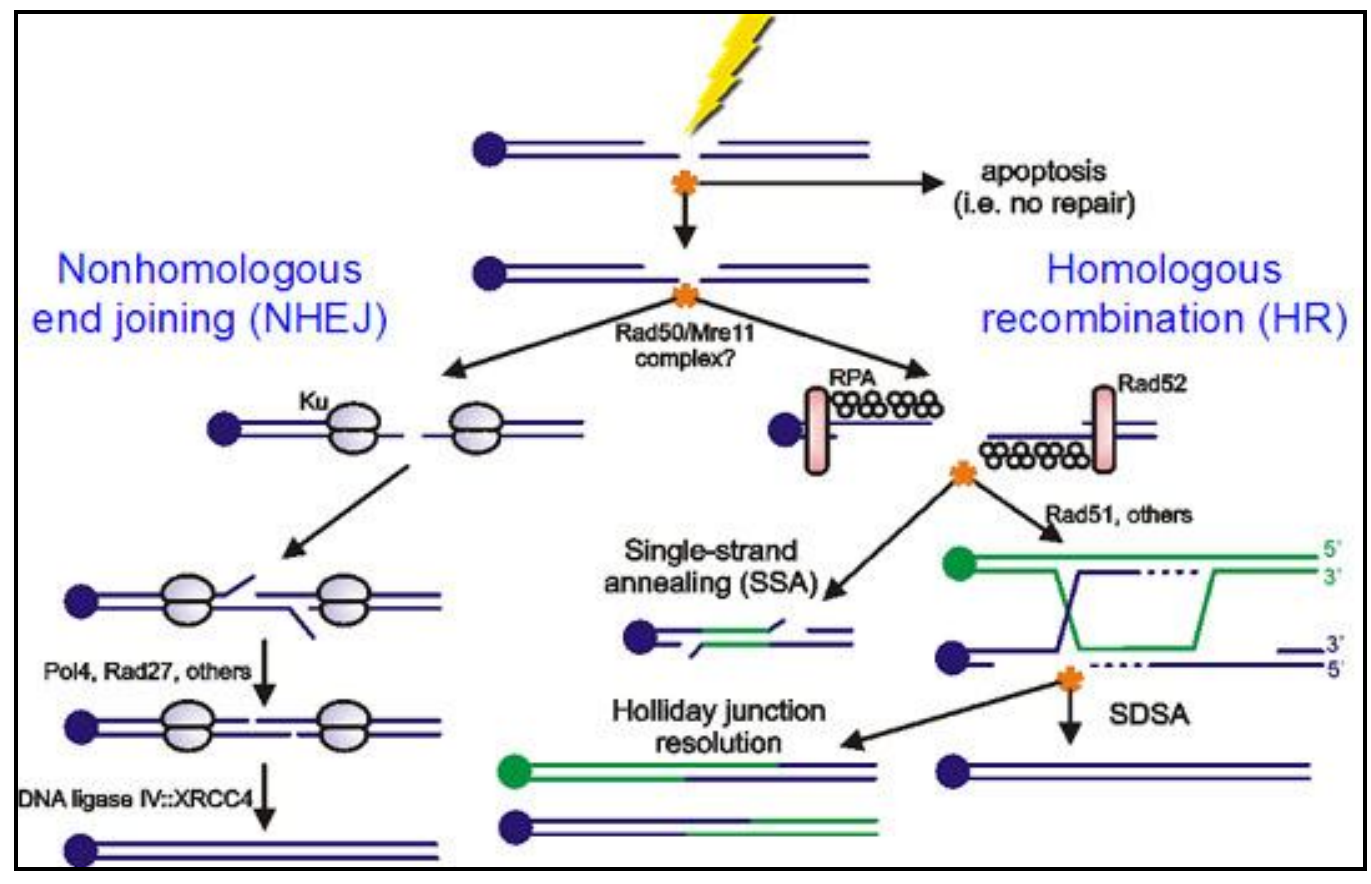

Figure 7 The pathways of DSB repair

DNA DSBs are repaired by either NHEJ or HR. In NHEJ, the broken DNA ends are bound by the KU70/KU80 heterodimer and are processed prior to ligation. In contrast, HR is an error-free repair pathway that utilizes as template to repair DSB a sister chromatid. http://tewlab.path.med.umich.edu/ResearchProjects.html

In contrast to $\mathrm{HR}$, non-homologous end joining does not require a homologous template for DSB repair and usually results in the correction of the break in an error-prone manner. Essential to the NHEJ pathway is the activity of the 
$\mathrm{Ku} 70 / \mathrm{Ku} 80$ heterodimeric protein [48]. The $\mathrm{Ku}$ heterodimer initiates NHEJ by binding to the free DNA ends (Fig.7) and recruiting other NHEJ factors such as, LIF1 [49] the yeast homologue of human XRCC4 [50], NEJ1 a strong bindig partner of Lif1 globular head, and DNA Ligase IV to the site of injury. Because the ends of most DSBs generated by genotoxic agents are damaged and unable to be directly ligated, they often have to undergo limited processing by nucleases and/or polymerases before NHEJ can proceed. The nuclease(s) responsible for this processing remains to be determined, but strong candidates for this activity include the MRE11/RAD50/XRS2 complex [51,52]. The final step in NHEJ repair involves ligation of the DNA ends by Ligase IV [53].

\subsection{DNA damage tolerance pathways}

In addition to the true repair pathways, the postreplication repair (PRR) pathway or the so called DNA damage tolerance (DDT) pathway allows lesions or structural aberrations that block replicative DNA polymerases to be tolerated. There are two bypass mechanisms: an error-free mechanism that involves a temporary switch to an undamaged template for synthesis past the lesion and an error-prone mechanism that utilizes specialized translesion synthesis DNA polymerases to directly synthesize DNA across the lesion [54].

UV-induced DNA lesions are usually repaired by NER, but if this pathway is not functional, these lesions will persist into $\mathrm{S}$ phase and interfere with DNA replication. This is manifested in the appearance of single-stranded DNA breaks (or nicks), which can be observed through separation of genomic DNA in an alkaline sucrose gradient [55-58]. After a short incubation period the fragmented genomic DNA converts to larger molecular weight species, similar to the DNA of unirradiated controls [55-58]. This restoration process is defined as postreplication repair. The low molecular weight DNA detected using alkaline sucrose gradients is assumed to arise from stalled replication forks creating areas of single-stranded gaps $[55,57,58]$. The lesions responsible for stalling replication are not removed from the DNA during this process, and persist even after the gaps are resolved [59, 60], that is why post replication repair is called as DNA damage tolerance. 
In yeast, Saccharomyces cerevisiae stalled replication forks at DNA damage sites are rescued by two independent pathways: a $R A D 52$ dependent recombinational mechanism and a RAD6-RAD18 dependent DNA damage tolerance [61].

\subsubsection{Rad52 dependent recombinational pathway}

Genes of the RAD52 pathway, which are indispensable for mediating DSB repair by HR, contribute also to the repair of discontinuities that form in the newly synthesized DNA in UV-irradiated yeast cells [57].

It is highly probable that the gap left opposite the DNA lesion on the lagging strand is filled in by the action of the $R A D 52$ group proteins via a nonrecombinational pathway, wherein the Rad51-coated single stranded nucleoprotein filament invades the DNA duplex on the leading strand side and the gap on the lagging strand is then filled in by DNA synthesis using the newly synthesized leading strand as the template $[62,63]$. The reason for suggesting a nonrecombinational mode of PRR for the Rad52-dependent pathway is that recombination is normally suppressed in yeast cells and it is only in the absence of Srs2 DNA helicase [64-66] or in the absence of Siz1mediated PCNA sumoylation [67-69] that the recombinational repair pathway becomes activated.

\subsubsection{Rad6-Rad18 dependent DNA damage tolerance pathway}

RAD6 and RAD18 were isolated in a screen to identify UV-sensitive $S$. cerevisiae mutants [70]. Both rad6 and rad18 mutants were sensitive to a wide range of DNA damaging agents $[57,58]$. Prior to any biochemical studies on Rad6, it was observed that rad6 cells displayed increased spontaneous mutagenesis and a loss of UV-induced mutagenesis [71-73]. These initial results led to the conclusion that the $R A D 6$ pathway promoted damage-induced mutagenesis [72]. It was later confirmed that the mutagenic response was indeed dependent upon RAD6 and RAD18 [74, 75]. Rad6 is one of 13 ubiquitin-conjugating enzymes (Ubcs) in S. cerevisiae and is involved in diverse cellular functions. Rad6 and Rad18 exist in a tight complex in the cell $[76,77]$ and are required for both error-free and mutagenic bypass processes. They govern at least three different damage bypass pathways [57, 78, 79] (a) the REV1, REV3, REV7-dependent error-prone translesion synthesis (TLS); (b) the $R A D 30$-dependent error-free translesion DNA synthesis and (c) the RAD5-dependent error-free postreplication repair (Fig.8). The first step in the activation of all three 
patyways is the Rad6-Rad18 dependent monoubiquitination of proliferating cell nuclear antigen (PCNA) at its K164 lysine residue [80, 81]. PCNA, the sliding clamp encircling DNA is the processivity factor of DNA polymerases and a key component of the replication machinery. PCNA ubiquitination by Rad6-Rad18 occurs only when PCNA is loaded onto DNA [82-84].

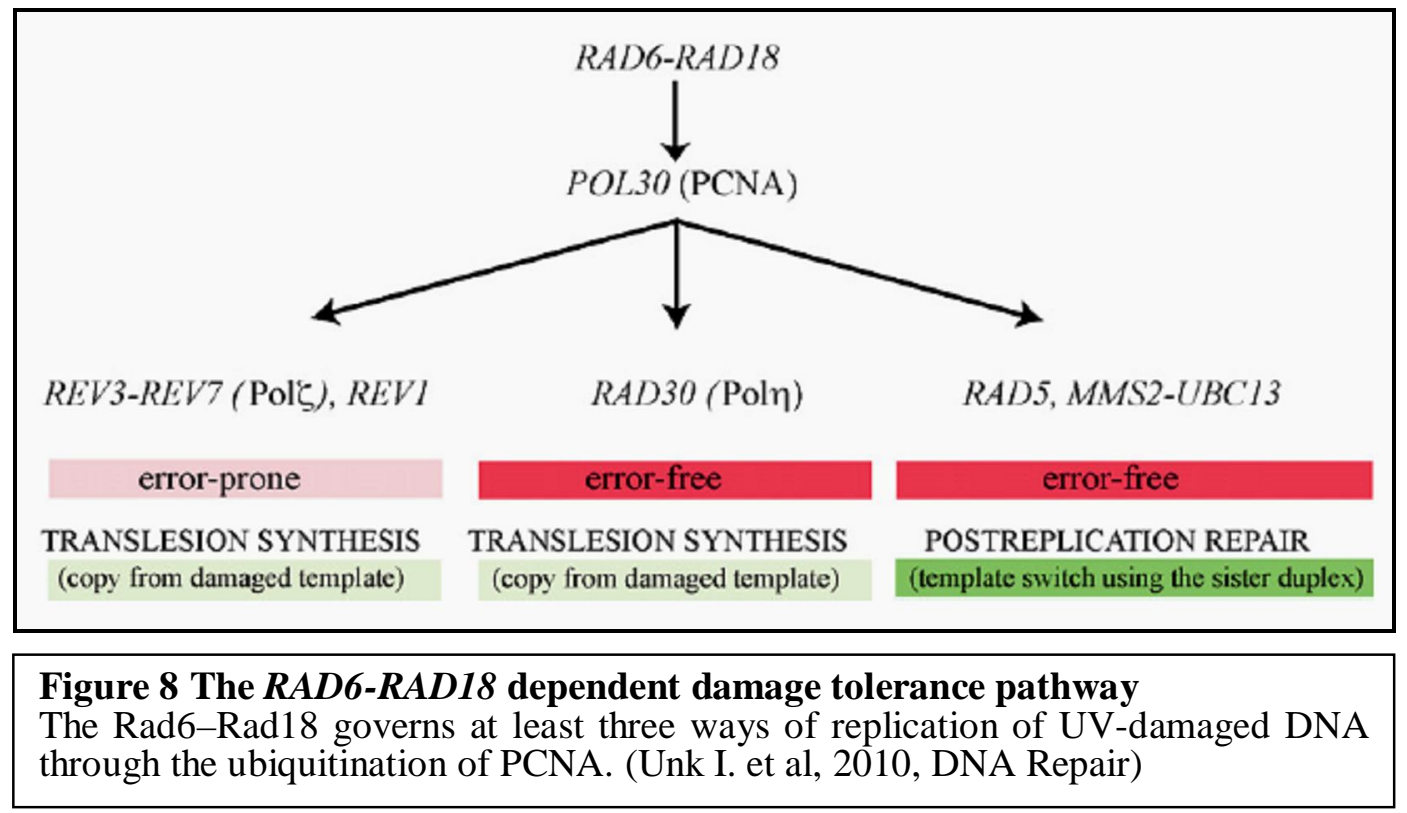

\subsubsection{Error-free post replication repair}

Rad5, Mms2 and Ubc13 have been so far the only assigned members to the error-free PRR sub-branch of Rad6-Rad18 (Fig.8). The three proteins form an ubiquitin-conjugating-ligating complex. Deletion of $M M S 2$ or $U B C 13$ results in moderate UV-sensitivity, while RAD5 deletion exhibits much higher UV-sensitivity [85]. The high sensitivity of the rad5 strain indicates that either PRR is not completely inhibited in the lack of $M M S 2$ or $U B C 13$, or that $R A D 5$ has additional role(s) beside PRR. Alkaline sucrose gradient sedimentation experiments helped to clarify the individual contribution of different genes in PRR and proved that in cells exposed to acute high dose of UV light, the repair of discontinuities is equally impaired in the absence of either $M M S 2$ or $R A D 5$ [79, 85]. This suggests that the higher UV-sensitivity of the rad5 strain is due to the other functions of Rad5 besides PRR. Indeed, Rad5 has been shown to play a limited role in translesion synthesis, and 
also in double-strand break repair and in the repair of DNA minor groove adducts in connection with nucleotide excision repair proteins $[72,85,86]$.

Rad5 belongs to a subgroup of the SWI/SNF2-like family characterized by a RING finger domain (Fig.9), characteristic of ubiquitin ligases, inserted between the C-terminal helicase motifs III and IV of the seven helicase modules. In addition to the helicase and RING domains, Rad5 has a HIRAN domain in its $\mathrm{N}$-terminus followed by a leucine heptad repeat motif $[87,88]$.

The ubiquitin ligase and the ATP-ase functions of Rad5 have been shown to be equally important for PRR, since inactivation of any of these activities by mutations, confers the same level of PRR defect as the RAD5 deletion in sucrose gradient experiments [85]. A function of the ubiquitin ligase activity of Rad5 in PRR has been determined to promote the polyubiquitination of PCNA [80, 89, 90]. In rad5, $m m s 2$ or $u b c 13$ deletion strains only the monoubiquitylated form of PCNA appears. Similarly to ubi (K63R) mutants, which express a ubiquitin variant incapable to form polyubiquitin chains linked through lysine 63, as a sole source of ubiquitin [77]. Since in these mutants mutagenesis is proficient, the K63-linked polyubiquitination of PCNA by Rad5 and Mms2-Ubc13 is necessary only for the Rad5-dependent PRR to operate $[81,87]$.

The various genetic and biochemical observations have suggested a role for Rad5 in mediating error-free lesion bypass by transient template switching. In this process the DNA helicase activity of Rad5, which is highly specialized for replication fork regression, could promote template switching and a copy choice type of DNA synthesis, where the lesion on the leading strand is bypassed by template switching using the newly synthesized lagging strand as the template that would be formed upon fork regression $[61,91]$.

In recent years two homologs of Rad5 have been identified in human cells, the HLTF and SHPRH proteins (Fig.9), showing 39\% and 21\% similarities to Rad5, respectively [92-95]. Both HLTF and SHPRH can form multiprotein complexes with human Rad6-Rad18 and Mms2-Ubc13. Furthermore, in vitro both HLTF and SHPRH function as ubiquitin ligase for Mms2-Ubc13 dependent lysine 63 linked polyubiquitination of PCNA, previously monoubiquitylated by Rad6-Rad18. Both HLTF and SHPRH promote PCNA polyubiquitination in vivo. Rad5, HLTF and SHPRH belong to the SWI/SNF2 family of DNA dependent ATPases [96-103]. 


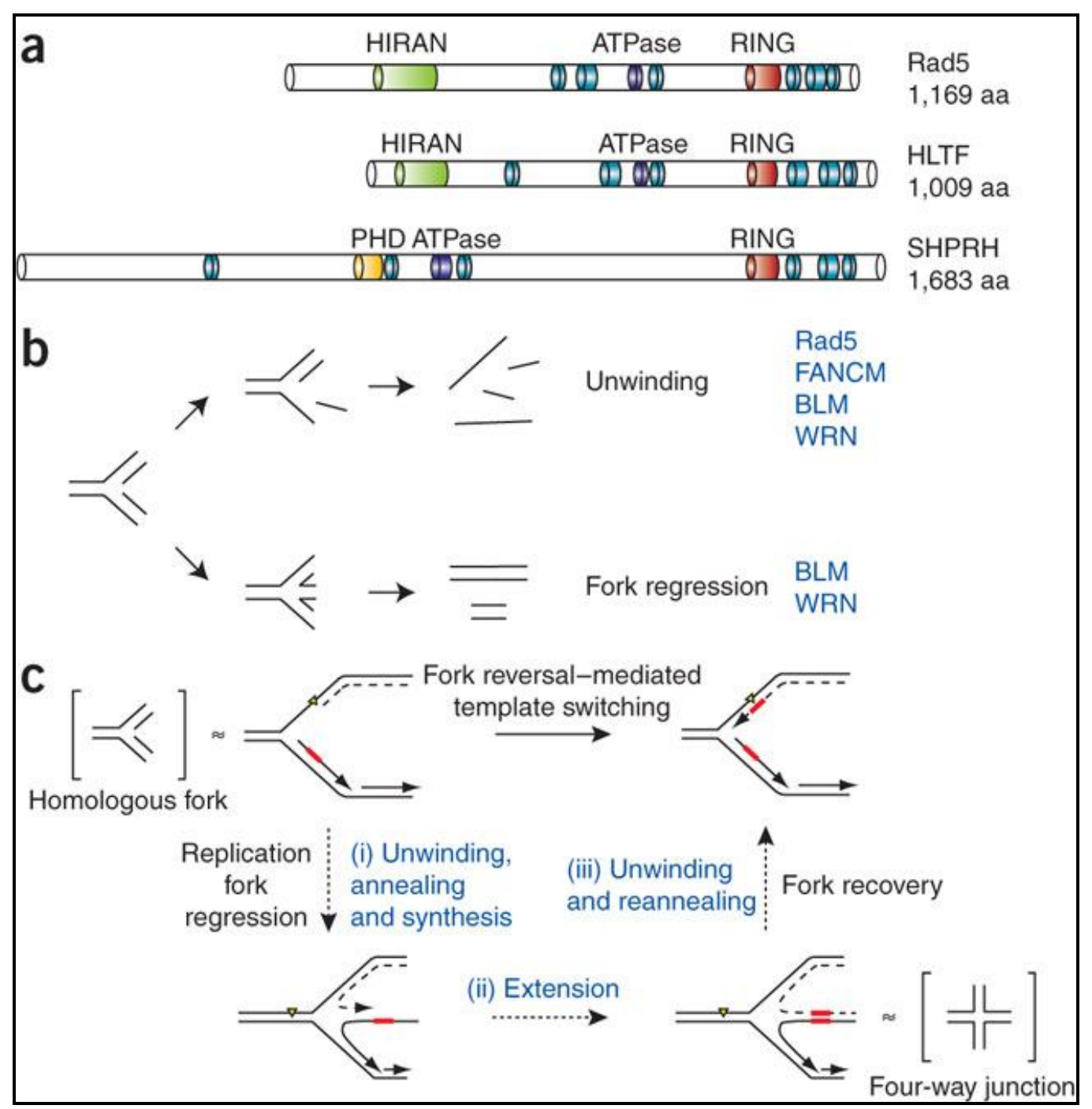

Figure 9 Domain architecture and functions of the E3 ubiquitin ligase Rad5 and its putative orthologs SHPRH and HLTF

(a) Structural comparisons between $S$. cerevisiae Rad5 and its human orthologs, HLTF and SHPRH. (b) The possible effects of helicase activity on a model homologous fork substrate. Helicases known to exhibit these activities are listed in blue. (c) A possible mechanism for template switching mediated by fork reversal. Model four-way junction and homologous fork structures, which are known substrates of Rad5 in vitro, are placed in brackets adjacent to the fork structures that they are thought to mimic. Yellow triangle, replication-blocking lesion; dashed line, leading strand; red box, template. (Chang D.J. et al, 2009, Nature Chemical Biology) 


\subsubsection{Translesion synthesis: $\operatorname{Rev1,~Rev3,~Rev7~and~Rad30~}$}

Translesion synthesis is a DNA damage tolerance process that allows the DNA replication machinery to replicate past DNA lesions such as thymine dimers or AP sites [104]. It involves switching regular DNA polymerases for specialized translesion polymerases, with less restrictive active sites that can facilitate the insertion of bases opposite damaged nucleotides. TLS polymerases often have low fidelity (high propensity to insert wrong bases) on undamaged templates relative to replicative polymerases. However, many are extremely efficient at inserting correct bases opposite specific types of damage. From a cellular perspective, risking the introduction of point mutations during translesion synthesis may be preferable than resorting to more drastic methods, which may cause gross chromosomal aberrations or cell death. All TLS polymerases except one, Polל, are Y-family polymerases that lack a 3'-5' proofreading exonuclease activity that could correct misincorporations and contain relatively non-restrictive active sites compared with the replicative polymerases [105].

At a site of lesion, PCNA is ubiquitinated at its K164 lysine residue (Fig. 10) by the Rad6-Rad18 protein complex to provide a platform for the specialized polymerases to bypass the lesion [106]. After translesion synthesis, extension is required. This extension can be carried out by the same TLS polymerase if the TLS is error-free, as in the case of the T-T dimer bypass by Pol $\eta$, yet if TLS results in a mismatch, a specialized polymerase is needed to extend it; Polל. So when a lesion is encountered, the replication fork stalls, the replicative polymerase is exchanged to a TLS polymerase, that inserts nucleotides opposite lesions and the same or a second TLS polymerase extends from it. After bypass the TLS polymerase is switched back to the replicative polymerase to continue replication [107].

To study this mutagenic process in yeast, Lemontt [108] isolated S. cerevisiae mutants incapable of reverting the arg4-17 and lys 1-1 alleles in response to UV irradiation. These reversionless mutations (rev1, rev2, rev3 and later rev7) [109] rendered cells moderately UV-sensitive, indicating that mutagenesis was indeed a damage tolerance mechanism. 


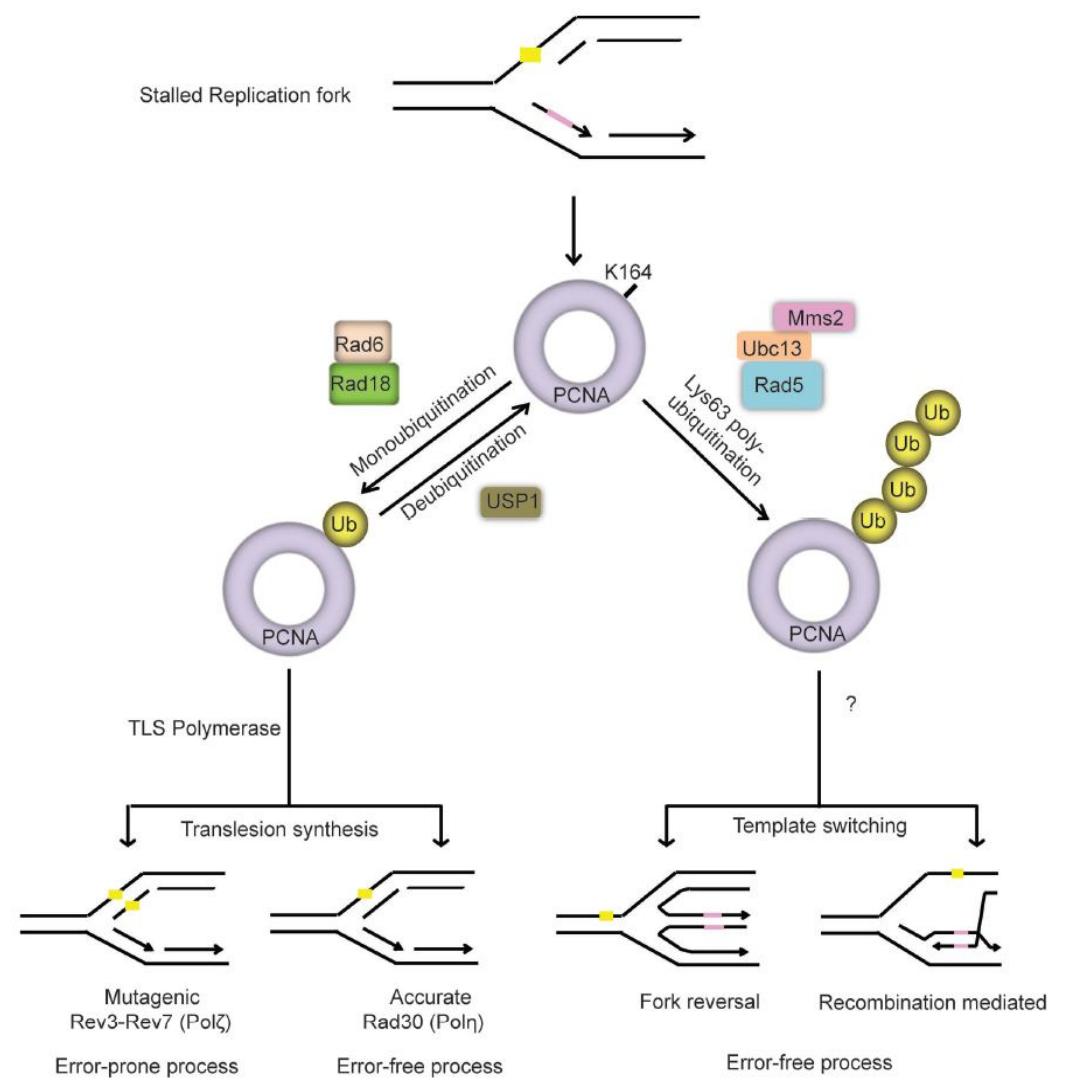

Figure 10 DNA damage tolerance pathway (DDT)

Lesions (yellow Square) in the DNA template block replication fork progression. Upon genotoxic stress, PCNA is ubiquitylated at K164 to initiate DDT pathways. Monoubiquitination of PCNA by RAD18-RAD6 promotes TLS, while polyubiquitination by Rad5 facilitates template switching. (Gargi Ghosal et al, 2012, Traslastional Cancer Research)

Rev1, the first characterized eukaryotic Y-family member, is a C-specific DNA polymerase that also inserts a dCMP efficiently opposite a template abasic site and is probably responsible for $60-85 \%$ of the bypass events at an abasic site in vivo [110]. The yeast rev1 mutant displays a complete loss of mutagenesis activity comparable to that of rev3. Analysis of site-specific mutations confirms that the Rev1 enzymatic activity is not essential for TLS, but its BRCT domain and polymeraseassociated domain [111] required for protein interactions which are necessary for mutagenesis implying a scaffold role of Rev1 in TLS. The Rev1 structure and function appears to be highly conserved in higher eukaryotes [110].

The possibility of a common mutageneic pathway in S. cerevisiae came from the finding that rad6 was epistatic to rev3 for UV-sensitivity [72]. REV3 encodes a 
$173 \mathrm{kDa}$ protein with conserved DNA polymerase motifs [112]. Biochemical studies have shown that $\operatorname{Rev3}$ and $\operatorname{Rev7}$ dimerize to form DNA polymerase $\zeta$ [113]. Rev3, the catalytic subunit of Polל, belongs to the B-family DNA polymerases, which include the replicative polymerases $\alpha, \delta$, and $\varepsilon$. Unlike Pol $\delta$ or $\varepsilon$, however, Pol $\zeta$ lacks the proofreading exonuclease activity, and unlike the three replicative polymerases, Rev3 is not essential for cell viability or for growth in yeast cells. Disruption of REV3 in mice, however, causes embryonic lethality [114]. Both subunits of Pol $\zeta$, Rev3 and Rev7, are indispensable for UV mutagenesis $[109,115,116]$ and for mutagenesis resulting from TLS occurring through abasic sites [117] or through bases damaged by certain chemical agents but not others [118]. Pol $\zeta$ 's action, however, is not limited to the mutagenic bypass of DNA lesions, as it also enables error-free bypass through a variety of DNA lesions [78].

$\boldsymbol{R A D 3 0}$ was discovered by searching the Saccharomyces Genome Database for DinB-like sequences. In Escherichia coli, the $\operatorname{DinB}$ gene is required for the SOSinduced lambda untargeted mutagenesis pathway and confers a mutator phenotype [119] to the cell when the gene product is overexpressed. The purified DinB protein is a DNA polymerase [120]. Like $\operatorname{Din} B, R A D 30$ is UV-inducible [121, 122]. The rad30 mutant is moderately sensitive to killing by UV [121, 122], with minor sensitivities to other DNA damaging agents [122]. RAD30 has been placed in the RAD6 epistasis group by virtue of rad6 and radl8 being epistatic to rad30 for UV-sensitivity [121]. As rad30 was additive to rev1, rev3, and rev7 for UV-sensitivity, and the rad30 mutant displayed no defect in UV-induced reversion of $\operatorname{trp} 1-1, R A D 30$ was placed in the error-free arm of PRR [121]. Genetic results show that the RAD30 encoded Pol $\eta$ is needed for error free T-T dimer bypass [123]. Indeed in vitro Pol $\eta$ has low fidelity on an undamaged template, but it has a high fidelity over T-T dimers, where it inserts A's across from both T's [123], unlike Pold, which arrests before the T-T dimer.

Thus, Pol $\eta$ is required for error-free TLS of UV-induced DNA damage. It was further shown that Pol $\eta$ activity is required for both resistance to killing and prevention of mutagenesis in response to the UV irradiation of yeast cells [124]. Not only is Pol $\eta$ required for error-free TLS of UV-induced DNA damage, but it is also involved in $N$-methyl- $N$-nitro- $N$-nitrosoguanidine (MNNG) - induced mutagenesis. Thus, Pol $\eta$ is either error-prone or error-free, depending upon the DNA lesion encountered. 
Poln, a Y family polymerase, differs from the other TLS polymerases in its way of binding PCNA. Given, that PCNA is a homotrimer ring Poln, similarly to Pol $\delta$, binds the interdomain connector loop of PCNA through its conserved PCNAinteracting peptide motif [125]. Pol $\delta$ and Pol $\eta$ can bind the same PCNA ring simultaneously. Meanwhile Rev1 and Polל bind the intermolecular interface at the outer face of the PCNA ring $[126,127]$.

Different TLS polymerases are required to bypass different DNA lesions, as a rev1A, rev3A or rev74 mutation abolishes abasic site-induced forward mutation [117], whereas the pol324 rad304 double mutant abolishes O6-MeG-induced forward mutation [128]. The unanswered questions are: how does the Rad6 pathway regulate polymerase switching and how is it decided which polymerase is used at a given lesion and at a given cell-cycle stage?

\subsection{Polymerase exchange}

The eukaryotic replicative DNA polymerase $\delta$ forms a stable holoenzyme complex with proliferating cell nuclear antigen. The holoenzyme is responsible for the highly accurate and processive DNA synthesis in eukaryotes [129]. However, in the presence of DNA damage Pol $\delta$ faces difficulties in synthesizing through the damaged base, which results in replication fork stalling and interruption in genomic DNA duplication. Prolonged stalling of the replication fork causes premature replication fork collapse and generates deleterious DNA damage in the form of dsDNA breaks that compromises genome stability [130]. Both error-free and error-prone damage avoidance mechanisms have been discovered in eukaryotic cells. In the error-free branch a template switch to sister chromatid after replication fork regression is proposed to ensure accurate DNA synthesis through the lesion $[2,79,91]$. In the error-prone branch a specialized TLS polymerase is believed to release the replication fork blockage by carrying out TLS through the damaged site [78, 131]. Although the essential role of the specialized Pols in TLS has been well documented, it is not clear how a specific Pol is selected and how an exchange between replicative and TLS Pols occurs. The answers to these questions are crucial for our understanding of TLS in view that it is essential to restrict the actions of TLS Pols only to the site of DNA damage to avoid further undesirable mutagenesis during genome replication. 
The phenomenon of "polymerase exchange" was first uncovered in T4 bacteriophage DNA replication. Using a catalytically impaired T4 replicative Pol (gp43) trap, it was found that gp43 from solution undergoes active exchange with gp43 in the holoenzyme [132]. A model was proposed to explain the Pol exchange process in T4 phage based on known x-ray crystal structures of both gp43 and gp45. In this model T4 clamp protein gp45 serves as a platform that interacts with both the resident and the incoming Pols. Because gp45 exists as homotrimer, a transient intermediate with two Pols tethered to the same clamp is possible with no major steric clashes given the flexibility in the gp43 C-terminal tail. Interestingly, DNA Pol exchange has also been shown in the bacteriophage T7 system through an interaction between Pol gp5 and helicase gp4 [133, 134].

During DNA replication in Escherichia coli, the DNA polymerase III holoenzyme will stall upon encountering a lesion. At this point, special translesion synthesis polymerases like pol IV take over and bypasses the lesion, allowing normal replication to continue. It remains unclear how TLS polymerases gain access to the primer site while stalled pol III sits there, although a "tool belt" model has been proposed by Indiani et al. [135]. Both enzymes are attached simultaneously to the polymerase $\beta$ subunit (the sliding clamp) and switch on and off as needed. Indiani et al. also found that such an intermediate is essential for the exchange between Pol IV and Pol III on DNA and is instrumental for the TLS in E. coli [135].

Asako Furukohri and colleagues propose an alternative where pol IV displaces pol III [136]. Using an assay measuring the DNA synthesis burst of primed pol III following the addition of dTTP, they found that adding pol IV before or after the nucleotide inhibited the synthesis burst. During this slow-down, the pol III* complex (two core units and the DnaX protein) no longer fractionated with the template DNA, instead being replaced by pol IV. The researchers propose a dynamic exchange model, where a stalled pol III complex enables pol IV to replace the stuck enzyme, and following lesion bypass, free pol III exchanges back in through mass action. In eukaryotes TLS is also indispensable for the fitness of the organism.

Elegant genetic studies in Saccharomyces cerevisiae revealed the complex nature of the initiation and regulation of TLS inside the cell $[67,80,81]$. Hoege et al. [80] found that in the yeast cell TLS function is directly linked to the covalent modification of PCNA by monoubiquitin. In response to DNA damaging agents, PCNA is ubiquitinated at the conserved Lys-164 residue by Rad6, an E2 ubiquitin 
(Ub)-conjugating enzyme, and Rad18, a RING finger-containing E3 Ub ligase. It was later established that the monoubiquitination of PCNA by Rad6/Rad18 activates the TLS by Poln $[67,81]$. Recently, it was found that many Y-family TLS Pols contain an Ub-binding domain (UBD) [83, 137], and from coimmunoprecipitation studies, it has been inferred that human Poln interacts with monoubiquitinated PCNA through both the UBD and the PCNA interacting protein (PIP) motif [137, 138]. An efficient exchange of $S$. cerevisiae Pol $\delta$ with Pol $\eta$ requires both the stalling of the holoenzyme and monoubiquitination of PCNA. PIP is strictly required for Pol exchange. Furthermore, the monoubiquitin moiety needs to be removed from PCNA after the lesion-bypass synthesis to resume normal DNA synthesis by Pol $\delta$ [139]. Despite the recent advance in our knowledge of TLS, the molecular basis of the regulation of TLS in eukaryotes is still not fully understood.

\subsection{Ubiquitin and its role in proteasomal degradation and DNA damage bypass}

Ubiquitin (originally, ubiquitous immunopoietic polypeptide) was identified as an $8.5 \mathrm{kDa}$ protein of unknown function expressed in all eukaryotic cells. The basic functions of ubiquitin and the components of the ubiquitination pathway were elucidated in the early 1980s by Aaron Ciechanover, Avram Hershko and Irwin Rose for which the Nobel Prize in Chemistry was awarded in 2004 [140, 141]. No ubiquitin and ubiquitination machinery are known to exist in prokaryotes. However, ubiquitin is believed to have descended from prokaryotic proteins similar to ThiS [142] or MoaD [143]. These prokaryotic proteins, despite having little sequence identity (ThiS has $14 \%$ identity to ubiquitin), share the same protein fold and sulfur chemistry with ubiquitin.

Ubiquitination (also known as ubiquitination) is an enzymatic, posttranslational modification process in which a ubiquitin protein is attached to a substrate protein. This process most commonly binds the last amino acid of ubiquitin (glycine 76) to a lysine residue on the substrate through an isopeptide bond [144]. Cases are known in which the amine group of a protein's N-terminus is used for ubiquitination, rather than a lysine residue [145]. In a few rare cases nonlysine residues have been identified as ubiquitination targets, such as cysteine, threonine and serine [146]. The end result of this process is the addition of one ubiquitin molecule 
(monoubiquitination) or a chain of ubiquitin molecules (polyubiquitination) to the substrate protein [147].

Monoubiquitination is the addition of one ubiquitin molecule to one substrate protein residue. Multi-monoubiquitination is the addition of one ubiquitin molecule to multiple substrate residues. Monoubiquitination of a protein can have different effects compared to the polyubiquitination of the same protein. The addition of a single ubiquitin molecule is thought to be required for to the formation of polyubiquitin chains [148]. Monoubiquitination affects cellular processes such as membrane trafficking, endocytosis, viral budding and DNA damage tolerance [149].

Polyubiquitination is the formation of a ubiquitin chain on a single lysine residue on the substrate protein. Following addition of a single ubiquitin moiety to a protein substrate, further ubiquitin molecules can be added to the first, yielding a polyubiquitin chain [148]. These chains are made by linking the glycine residue of a ubiquitin molecule to a lysine of ubiquitin bound to a substrate. Ubiquitin has seven lysine residues and an $\mathrm{N}$-terminus that may serve as points of ubiquitination, they are K6, K11, K27, K29, K33, K48 and K63. Lysine 48-linked chains were the first identified and are the best characterised type of ubiquitin chains. K63 chains have also been well characterised, whereas the function of other lysine chains, mixed chains, branched chains, $\mathrm{N}$-terminal linear chains and heterologous chains (mixtures of ubiquitin and other ubiquitin like proteins) remains more unclear [148, 149]. Lysine 48-linked polyubiquitin chains target proteins for destruction, by a process known as proteolysis. At least four ubiquitin molecules must be attached to a lysine residue on the condemned protein in order for it to be recognised by the $26 \mathrm{~S}$ proteasome [150]. This protein complex is a barrel-shaped structure comprising a central proteolytic core made of four ring structures, flanked by two cylinders that selectively allow entry of ubiquitinated proteins. Once inside, the proteins are rapidly degraded into small peptides (usually 3-25 amino acid residues in length). Ubiquitin molecules are cleaved off the protein immediately prior to destruction and are recycled for further use [151]. Although the majority of proteasomal substrates are ubiquitinated, there are examples of non-ubiquitinated proteins targeted to the proteasome[152]. The polyubiquitin chains are recognised by a subunit of the proteasome; S5a/Rpn10 [153]. Lysine 63-linked chains are not associated with proteasomal degradation of the substrate protein. Instead they allow the coordination of other processes such as endocyctic trafficking, inflammation, translation and DNA repair [154]. Normally in 
cells lysine 63-linked chains are bound by the ESCRT-0 complex, which prevents their binding to the proteasome [155].

Ubiquitination requires three types of enzymes; ubiquitin-activating enzymes, ubiquitin-conjuating enzymes and ubiquitin ligases, known as E1s, E2s and E3s, respectively. The process consists of three main steps (Fig.11):

1. Activation: Ubiquitin is activated in a two-step reaction by an E1 ubiquitin activating enzyme, which is dependent on ATP. The initial step involves production of a ubiquitin-adenylate intermediate. The E1 binds both ATP and ubiquitin and catalyses the acyl-adenylation of the C-terminus of the ubiqutin molecule. The second step transfers ubiquitin to an active site cycteine residue, with release of AMP. This step results in a thioester linkage between the C-terminal carboxyl group of ubiquitin and the E1 cysteine sulfhydryl group [144, 156]. While in Saccharomyces cerevisiae there is one E1 ubiquitin activating enzyme, the human genome contains two genes that produce enzymes capable of activating ubiquitin UBA1 and UBA6 [157].

2. Conjugation: E2 ubiquitin-conjugating enzymes catalyse the transfer of ubiquitin from E1 to the active site cysteine of the E2 via a trans(thio)esterification reaction. In order to perform this reaction, the E2 binds to both activated ubiquitin and the E1 enzyme. Humans possess 35 different E2 enzymes, whereas other eukaryotic organisms have between 16 and 35. They are characterised by their highly conserved structure; known as the ubiquitin-conjugating catalytic (UBC) fold [158].

3. Ligation: E3 ubiquitin ligases catalyse the final step of the ubiquitination cascade. Most commonly they create an isopeptide bond between a lysine of the target protein and the C-terminal glycine of ubiquitin. In general, this step requires the activity of one of the hundreds of E3s. E3 enzymes function as the substrate recognition modules of the system and are capable of interaction with both E2 and substrate. Some E3 enzymes also activate the E2 enzymes [159]. The anaphase-promoting complex (APC) and the SCF complex (for Skp1Cullin-F-box protein complex) are two examples of multi-subunit E3s involved in recognition and ubiquitination of specific target proteins for degradation by the proteasome [160]. In the ubiquitination cascade, E1 can bind with many E2s, which can bind with hundreds of E3s in a hierarchical way. Having levels within the cascade allows tight regulation of the ubiquitination machinery [161]. 


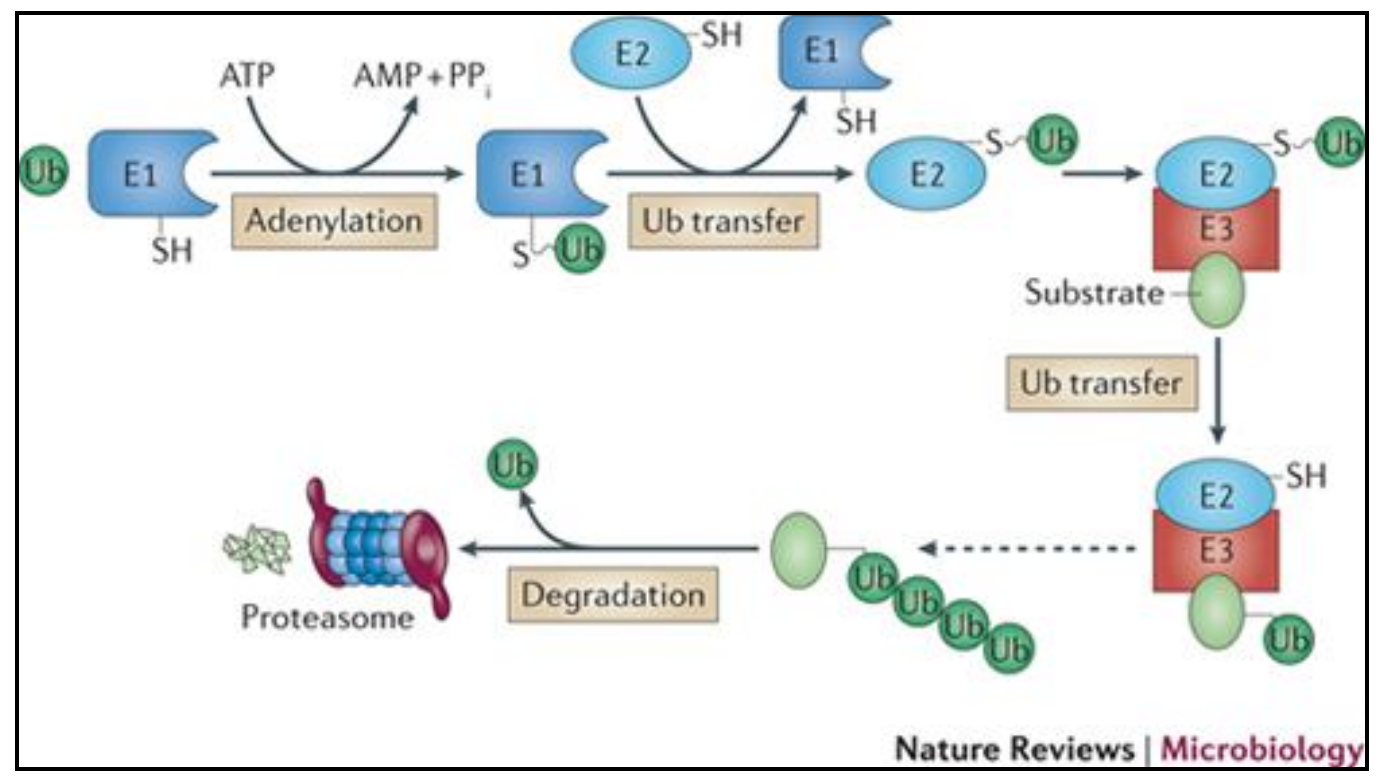

Figure 11 The Ubiquitin system

Ubiquitination requires three types of enzymes; ubiquitin-activating enzymes (E1s), ubiquitin-conjuating enzymes (E2s) and ubiquitin ligases (E3s). The E1 binds both ATP and ubiquitin, and transfers ubiquitin to an active site cycteine residue, with release of AMP. E2s catalyse the transfer of ubiquitin from E1 to the active site cysteine of the E2. E3s catalyse the final step of the ubiquitination cascade by creating an isopeptide bond between a lysine of the target protein and the C-terminal glycine of ubiquitin. (Julie Maupin-Furlow, 2012, Nature Reviews Microbiology)

\subsection{Def1-degradation factor 1}

Def1 (RNAPII Degradation Factor 1) is the product of the YKL054C ORF on Chr. XI of Saccharomyces cerevisiae [162]. It was first isolated as a Rad26-associated protein [163]. $\operatorname{Rad} 26$ is the yeast homologue for the best-studied Cockayne's syndrome gene [164], CSB, which codes for a Swi/Snf-like DNA-dependent ATPase. The DEF1 gene encodes a 738-amino-acid polypeptide with a theoretical and practical molecular mass of 84 and 120 kilodaltons in SDS-PAGE, respectively [162]. The amino-acid sequence of Def1 predicts a protein with unusually extensive regions of low complexity, such as a large region with homology to coiled-coil domains and very high glutamine content over almost the entire protein. The high glutamine content probably explains the aberrant gel-electrophoretic properties of the protein and probably because of extensive low complexity regions a convincing metazoan homologue of the protein has not yet been identified by database searching [165]. 
In Def1 the glutamine residues occupy $\sim 23 \%$ of the total sequence, from aa 381 to aa 480, which contains a coiled-coil domain of Def1, of which 65 residues are glutamines. It is believed that the expansion of glutamine repeats causes eight neurodegenerative diseases [166-168], including Huntington disease. In some of these neurodegenerative diseases, e.g. Huntington disease, the proteins with glutamine repeats have been shown to form granular and fibrous deposits in the cell nuclei of the affected neurons. In vitro, the recombinant 51- and 83-glutamine peptides of Huntington disease protein are able to form amyloid-like fibers. Although there are intervals between the segments of glutamines in the glutamine-rich region (aa 381480) of Def1, it is possible that the middle part of Def1, especially the glutamine-rich region, might mediate its oligomerization and thereby facilitate the interaction between DNA and other proteins, which presumably interact with the C-terminal of Def1 [169].

defl mutants are viable, but slow growing [162]. Genetic crosses revealed that the weak UV sensitivity of a rad26 deletion was not enhanced by additional defl deletion. In a radl6 (only defective in GGR) or rad14 (completely NER-deficient) strain defl deletion enhanced UV sensitivity. The fact that defl disruption synergies the UV sensitivity of a NER-deficient background indicates that DEF1 acts independent of the core excision repair reaction. Nevertheless, deletion of DEF1 alone did not affect the TCR rate as shown by unaltered repair kinetics in the transcribed and non-transcribed strand of the mutant strain compared to wild type cells [170].

In addition, defl mutation like rad26, failed to increase the UV-sensitivity of strains defective in other repair pathways, such as recombination repair and the DNA damage tolerance/post-replication repair pathway [162].

In order to explain defl strain behaviour in the epistatis analysis, Woudstra and colleagues suggested a possible link between Def1 and RNAPII-mediated transcription [170]. They show that defl cells are as sensitive to the transcription elongation inhibitor 6-azauracil (6AU) as strains lacking the prototype elongation factor TFIIS (coded by DST1) and defldst1 double mutant was extremely 6AU sensitive. Moreover, whereas defl and dst 1 single mutants grew at both $30^{\circ} \mathrm{C}$ and $37^{\circ} \mathrm{C}$, the double mutant grew very slowly at $30^{\circ} \mathrm{C}$ and was unable to grow at the elevated temperature [165]. 
Cells degrade irreversibly stalled RNAPII as a last resort when a transcription block, such as a DNA lesion, cannot be repaired or bypassed. Def1 is required for proteolysis of RNAPII in response to DNA damage. RNAPII is degraded in response to UV-irradiation in wild-type cells. Surprisingly, UV-induced RNAPII degradation occurs more rapidly and to a greater extent in rad26 cells than in wild-type cells. In contrast, cells lacking DEF1 did not degrade RNAPII at all, leading to apparent accumulation of the protein in response to DNA damage. These results demonstrate that Def1 is essential for damage-induced degradation of RNAPII in the presence of $\operatorname{Rad} 26$, but not for TC-NER [165], while $\operatorname{Rad} 26$ is required for normal TC-NER, it is not necessary for RNAPII degradation.

Together, these data suggests that cells contend with damage-stalled RNAPII by a two-pronged approach. First, rapid repair of the lesion by Rad26- mediated TCNER is attempted. If this fails, RNAPII is degraded via Def1-mediated ubiquitination/ degradation, presumably allowing the damage to be dealt with later via general genome repair $[165,171,172]$.

In vitro Def1 contributes directly to the preferential degradation of stalled/ arrested RNAPII ternary complex during transcript elongation by increasing the rate of its ubiquitination [172].

Def1 was identified also as an interactive partner of Rrm3 [169], which promotes the replication fork progression through both telomeric and subtelomeric DNA. Loss of Rrm3 resulted in very modest telomere lengthening, which is likely due to the replication defect in the telomere regions. In $\mathrm{rrm} 3$ cells replication fork pausing at both telomeric and subtelomeric DNA was observed [173]. Rrm3 is required for the normal replication of $\sim 1,400$ sites (including centromeres, tRNA genes, inactive replication origins, the silent mating type loci, telomeres, and rDNA) [173]. In $S$. cerevisiae, the telomere integrity is maintained through both telomere elongation/shortening and telomere end capping activities [174, 175]. In defl mutants, telomeres were $\sim 200$-bp shorter than that in wild-type cells. $D E F 1$ is also required for the stable maintenance of mitochondrial DNA and the telomere shortening phenotype seen in defl cells is not a secondary consequence of a mitochondrion defect. Telomerase, a specialized reverse transcriptase that is comprised of several subunits including Est1, Est2 (catalytic subunit), Est3, and Tlc1 (the RNA template), is responsible for the elongation of TG 1-3 tracts [176-179]. Disrupting any of them will cause progressive telomere shortening and eventually cellular senescence $[176,180$, 
181]. A combination of DEF1 null mutation with deletion of EST2 or EST3 resulted in an accelerated senescence phenotype, suggesting that Def1 is not involved in the telomerase recruitment pathway, but rather in telomere protection. This argument is supported by the observation that the N-terminal part of Def1 could bind DNA both in vitro and in vivo using telomeric DNA oligonucleotides [169]. In the absence of telomerase, cells escape senescence by either amplifying Y' regions or TG-telomeric repeats to generate type I or type II survivors, respectively $[182,183]$. Only type I survivors were recovered from defl, est2 and def1, est 3 double mutant cells, further suggesting that the function of Def1 in telomere maintenance is specific. Def1 is a positive regulator in telomere maintenance [169].

DEF1 was among the eight genes identified, whose deletion caused an increase in intracellular glutathione of more than 1.2-fold as compared to the wildtype strain. Glutathione is an antioxidant [184], preventing damage to important cellular components caused by reactive oxygen species such as free radicals and peroxides [185]. Because glutathione is synthesized through the sulfur-containing amino acids metabolism pathway the production of hydrogen sulfide $\left(\mathrm{H}_{2} \mathrm{~S}\right)$ was examined and the Def1-overexpressing strain formed brown-colored colonies on the YPDL plates, indicating that these strains overproduced $\mathrm{H}_{2} \mathrm{~S}$ [185].

Interestingly, in this study, both overexpression and deletion of DEF1 increased the content of intracellular glutathione, especially the oxidised state. These results suggest that overexpression or deletion of DEF1 induced some stress response through RNAPII. Preliminary results indicate that glutathione changes the level of reactive oxygen species in isolated cells grown in a laboratory [186, 187], which may reduce cancer development [188]. None of these tests were performed in humans. However, once a cancer has already developed, by conferring resistance to a number of chemotherapeutic drugs, elevated levels of glutathione in tumour cells are able to protect cancerous cells in bone marrow, breast, colon, larynx, and lung cancers [188].

Since DNA-damage-dependent ubiquitination of RNAPII also occurs in human cells, a mechanism similar to that in yeast can be envisaged $[165,189]$. However, no DEF1 candidate orthologue has been identified so far in mammals. The possible absence of a mammalian orthologue might be explained by the fact that multi-cellular organisms have other solutions to clear dangerously impeded cells. It has been shown that transcriptional blockage is a potent inducer of apoptosis [190], an option that is not applicable for single-celled organisms. 


\section{Goals and objectives}

Our main goal was to search for additional factors that affect DNA damage bypass. For this purpose we chose to examine the $D E F 1$ gene since from the literature it was known that deletion of $D E F 1$ rendered cells sensitive to UV-radiation, and the defl rad18 double deletion mutant showed the same UV-sensitivity as the rad18 single mutant [162], which might indicate an epistatic relationship, where the function of $D E F 1$ was dependent on $R A D 18$.

To determine the involvement of $D E F 1$ in the RAD6-RAD18 pathway, we planned the following steps:

1. To analyse the genetic relations between $D E F 1$ and members of all three branches of the RAD6 pathway upon DNA damage.

2. To check the interaction between $D E F 1$ and members of the RAD6 pathway.

3. To determine the exact function of Def1 


\section{Materials and methods}

\subsection{Media}

- YPD medium: 2\% D-glucose (Molar Chemicals Kft.), 2\% bacto peptone (MERCK), and $1 \%$ yeast extract (MERCK) in destilled water, autoclaved for 25 $\min$ at $110^{\circ} \mathrm{C}$. For plates, $1.7 \%$ agar (agar bacteriological, Molar Chemicals Kft.) was added before autoclaving.

- Synthetic complete medium: $2 \%$ D-glucose, $0.17 \%$ Difco yeast nitrogen base without amino acids and with ammonium sulfate and synthetic complete mixture. Synthetic complete mixture contained the following components (all from Sigma) weighed in as powder and added before autoclaving (final concentrations are indicated): adenine $40 \mathrm{mg} /$ liter, L-arginine $30 \mathrm{mg} /$ liter, L-histidine $20 \mathrm{mg} / \mathrm{liter}$, Lisoleucine $20 \mathrm{mg} / \mathrm{liter}$, L-leucine $30 \mathrm{mg} / \mathrm{liter}, \mathrm{L}-\mathrm{lysine}-\mathrm{HCl} 30 \mathrm{mg} / \mathrm{liter}, \mathrm{L}-$ methionine $20 \quad \mathrm{mg} /$ liter, L-phenylalanine $\quad 50 \quad \mathrm{mg} /$ liter, L-tryptophane 30 mg/liter, L-tyrosine $30 \mathrm{mg} /$ liter, uracil $20 \mathrm{mg} / \mathrm{liter}$, L-valine $100 \mathrm{mg} / \mathrm{liter}$.

- Drop-out media: Synthetic complete medium lacking nutrilite supplements. For example, "uracil-less" medium is without uracil (SC-ura).

- Canavanine medium: SC -arg containing 40 mg/liter L-canavanine (Sigma).

- 5-Fluoroorotic acid plates: SC plates containing $1 \mathrm{~g} /$ liter 5-fluoroorotic acid (5FOA, Fermentas), added after autoclaving as powder when medium was cooled to $\left.50^{\circ} \mathrm{C}\right)$.

- G418 plates: YPD plates containing G418 (200 $\mu \mathrm{g} / \mathrm{ml}$; Sigma), added as solution $\left(50 \mathrm{mg} / \mathrm{ml}\right.$ in water) after autoclaving when medium was cooled to $50^{\circ} \mathrm{C}$.

- MMS plates: YPD plates containing MMS (100\% Sigma), added as solution (diluted in water) in different concentrations after autoclaving when medium was cooled to $50^{\circ} \mathrm{C}$.

For sterile filtered media, all components were dissolved in water and filtered through Millex GV disposable sterile filter units $(0.22 \mu \mathrm{m}$ pore size; Millipore).

\subsection{Yeast nomenclature}

Gene names, also referred to as genetic names (for example, $D E F 1$ or $R A D 5$ ), are conferred upon genes by researchers on the basis of genetic, biochemical, or molecular characterization. Most genes having Gene Names are ORFs. The accepted 
format for gene Names in $S$. cerevisiae is comprised of three uppercase italic letters followed by an Arabic number. Generally, the letters signify a phrase (referred to as the "Name Description" in SGD) that provides information about a function, mutant phenotype, or process related to that gene, for example "ADE" for "ADEnine biosynthesis" or " $C D C$ " for "Cell Division Cycle". Protein products are designated by the corresponding gene symbol in nonitalic type with an initial capital letter (for example Def1). Deletion mutants are designated by the corresponding gene symbol in italic type smallcase letters (for example defl) and usualy mean the gene is deleted form ATG to STOP codon.

\subsection{Yeast strains and growth conditions}

Saccharomyces cerevisiae strains used (table 1) in the genetic studies are haploid and isogenic to wild type strain BY4741 (MATa, his3-D1, leu2, met15, ura3) and were obtained from the Euroscarf collection. Double deletion mutant strains were generated by one-step gene disruption method [191]. Strains used for whole cell extract preparation are haploid and isogenic to EMY74.7 (MATa, his3-D1, leu2-3, leu2-112, trp1D, ura3-52). Chromosomally C-terminally tagged POL3, POL31 and POL32 with 3 copies of the hemagglutinin epitope tag (3HA) were also created in EMY74.7 strain, made bar14.

The protease deficient yeast strain used for protein overexpression, BJ5464 (Mat $\alpha$, ura3-52 trp1 leu2-D1 his3-D200 pep4::HIS3 prb1-D1.6R can1 GAL) was obtained from the Yeast Genetic Stock Center (Berkeley, CA). BJ5464 contains deletions of the vacuolar proteases PEP4 and PRB, which are responsible for most proteolytic activity observed in yeast supernatants and extracts [192].

Yeast strains used for yeast two hybrid assays HF7c (genotype: MATa, ura352, his3-200, lys2-801, ade2-101, trpl-901, leu2-3, 112, gal4-542, gal80-538, LYS2 :: GAL1-HIS3, URA3 :: (GAL4 17-mers) 3-CYC1-lacZ) and pJ69-4A (MATa leu2-

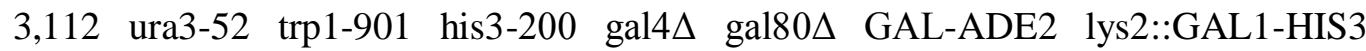
met2::GAL7-Lac Z) were obtained from BD Biosciences Clontech. All yeast strains were grown at $30^{\circ} \mathrm{C}$.

The rpn7-3 mutant and its corresponding W303 (MATa ura3-52 trp1 $\Delta 2$ leu23_112 his3-11 ade2-1 can1-100) wild type strain [193], a kind gift from Erika Isono, were used in experiments showing the effect of temperature sensitive inhibition of the 
proteasome. Poly-ubiquitination of Pol3 was shown in MHY500 (MATa his3-200 leu2-3,112 ura3-52 lys2-801 trp1-1) strain background [194]. The MHY500 was a kind gift from Mark Hochstrasser.

\begin{tabular}{|l|l|}
\hline Strain & Genotype \\
\hline BY4741 & MATa, his3-D1, leu2, met15, ura3 \\
\hline EMY74.7 & MATa, his3-D1, leu2-3, leu2-112, trp1, ura3 \\
\hline BJ5464 & $\begin{array}{l}\text { MATa, ura3-52 trp1 leu2-1 his3-200 pep4::HIS3 prb1-D1.6R can1 } \\
\text { GAL }\end{array}$ \\
\hline HF7c & $\begin{array}{l}\text { MATa, ura3-52, his3-200, lys2-801, ade2-101, trp1-901, leu2-3, 112, } \\
\text { ga14-542, gal80-538, LYS2 :: GAL1-HIS3, URA3 :: (GAL4 17-mers) } \\
\text { 3-CYC1-lacZ }\end{array}$ \\
\hline pJ69-4A & $\begin{array}{l}\text { MATa leu2-3,112 ura3-52 trp1-901 his3-200 gal4D gal80 } \\
\text { ADE2 lys2::GAL1-HIS3 met2::GAL7-Lac Z }\end{array}$ \\
\hline W303 & MATa ura3-52 trp1 $\Delta 2$ leu2-3_112 his3-11 ade2-1 can1-100 \\
\hline MHY500 & MATa his3-200 leu2-3,112 ura3-52 lys2-801 trp1-1 \\
\hline
\end{tabular}

Table 1 Yeast strains used in this study

\subsection{Plasmids}

pGBKT7 (TRP1, $2 \mu \mathrm{m}$ ) Gal4p DNA binding domain vector and pGADC3 (LEU2, $2 \mu \mathrm{m})$ Gal4p activation domain vector were obtained from Clontech Laboratories, Inc. DEF1 and other DDT genes were cloned into the Gal4 DNAbinding domain vector pGBKT7. All yeast two-hybrid prey plasmids were generated by introducing the corresponding cDNAs into the transcriptional activation domain vector $\mathrm{pGADC} 3$.

Gene blaster plasmids containing the deletion 'cassette' were constructed in a sequential, one-step PCR reaction and two step cloning process. Two pairs of primers were used, 24bp UPTAG and 24bp DOWNTAG primers which amplify a region consisting of (5' to $\left.3^{\prime}\right) 700$ to $1000 \mathrm{bp}$ of genomic sequence that flank either the $5^{\prime}$ or $3^{\prime}$ end of the ORF (directly proximal and distal to the START and STOP codons 
respectively) and used to replace each yeast gene of interest. These two amplified regions were cloned in the proper orientation into the pUC19 vector and the URA3 marker was inserted afterwards in between the two regions.

DEF1 and the genes coding for the three subunits of Pold, POL3, POL31 and POL32 respectively, were cloned in frame in N-terminal GST fusion in pID370, pID458 and pID460, respectively (pBJ842 backbone) [195].

Def1 was expressed, for complementation in yeast, from the centromeric vector pID394 (p416ADH backbone) [196].

In the plasmid pRS426-pCUP1-His7-Ubiquitin (G76A) [197], a kind gift from William P. Tansey, the mutation was reversed by site directed mutagenesis resulting in plasmid pID198.

\subsection{Generation of deletion strains by homology based gene replacement}

Deletions of different genes were made by using the one-step gene disruption method [191] (Fig 4). In mutants all or most of their open reading frames (ORFs) were replaced by the URA3, HIS3, or TRP1 genes as selectable markers. Briefly, cells were grown to logarithmic phase at $30{ }^{\circ} \mathrm{C}$ in liquid yeast extract-peptone-dextrose (YPD) medium. Cells were washed once in sterile water and resuspended in a final volume of $500 \mu 1\left(2 \times 10^{9}\right.$ cells $\left./ \mathrm{ml}\right)$, which is about $400 \mu 1$ of $100 \mathrm{mM}$ lithium acetate (LiAc), pH 7.5 and $100 \mu \mathrm{l}$ of cells. For integrative transformation, $50 \mu 1$ of cells were pelleted and mixed with $250 \mu 1$ of $50 \%$ PEG4000, 36 $\mu 11 \mathrm{M} \mathrm{LiAc,} 25 \mu \mathrm{l}$ of sonicated herring sperm DNA $(2 \mathrm{mg} / \mathrm{ml})$, and $50 \mu 1$ of MQ. Finally the linearized deletion generating plasmid (1-5 $\mu$ g of DNA) was added to the cells and incubated for 30 minutes at $30{ }^{\circ} \mathrm{C}$. After incubation the cells were exposed to heat shocked at $42{ }^{\circ} \mathrm{C}$ for 20 minutes, washed in sterile water and plated on synthetic complete (SC) media lacking either uracil, histidine, or tryptophan, depending on the selectable marker used. Yeast colonies were grown for three to five days at $30{ }^{\circ} \mathrm{C}$ and screened for integration by standard polymerase chain reaction (PCR). To remove the URA3 gene from the integrated "gene blaster" [198], strains were plated on SC plates containing 1 $\mathrm{mg} / \mathrm{ml} 5$-fluoroorotic acid (5-FOA) and incubated at $30{ }^{\circ} \mathrm{C}$ for three to five days. PCR was performed on genomic DNA of each strain to confirm loss of the URA3 gene. Multiple deletions were generated by sequential gene deletion using the same method. 


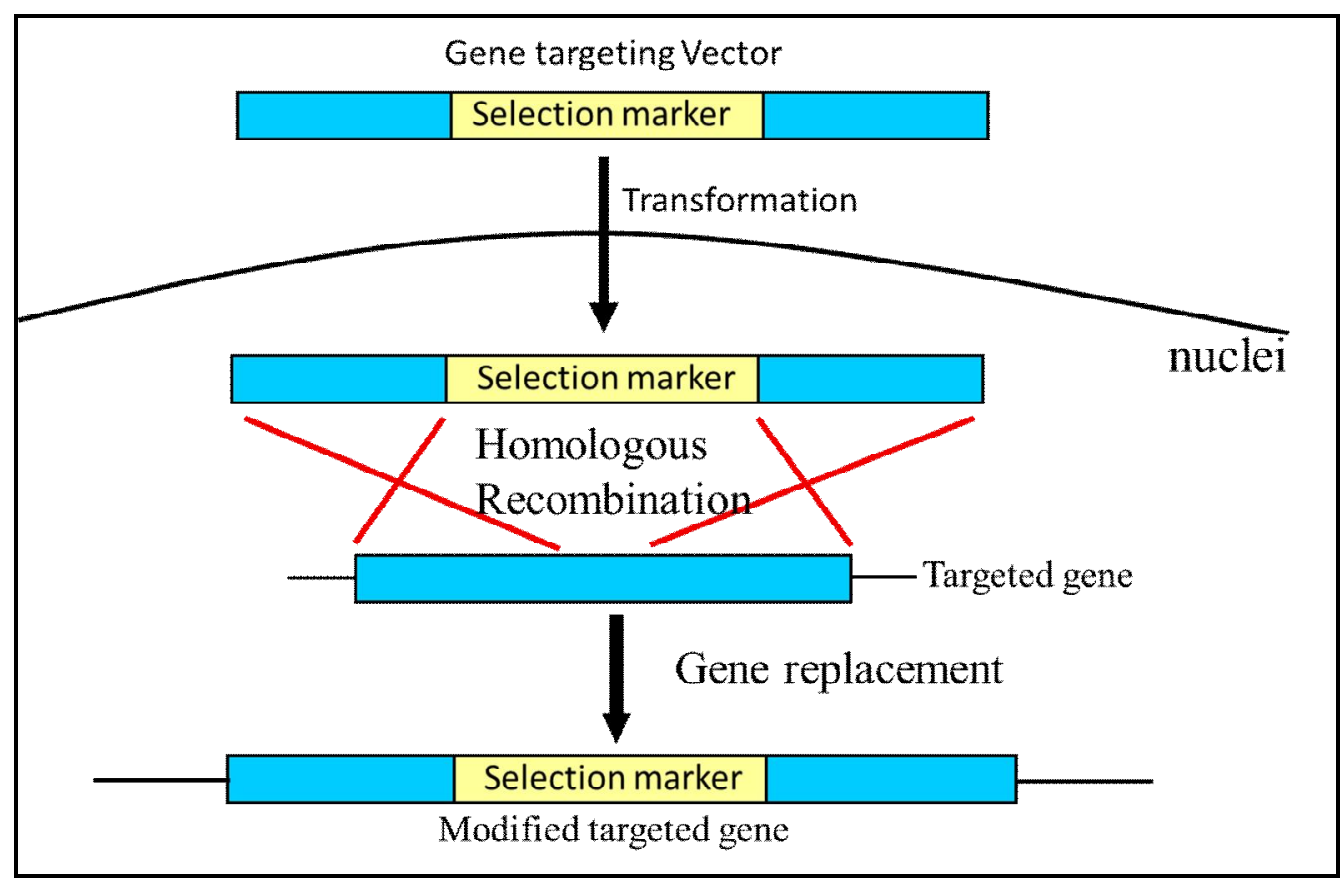

Figure 12 Schematic diagram of the principle of Gene Targeting

(Sivakumar Gowder, 2012: Cell Interaction, chapter 9)

\subsection{Epitope tagging}

To simplify the detection of polymerase $\delta$ subunits, POL3, POL31 and POL32, we used epitope tagging [199]. The 3HA6HIS double tag cassette [200] and the 3HA cassette [201] for C terminal tagging of proteins, were amplified by PCR, purified and transformed into yeast. The tag was integrated based on sequence homology and was checked by PCR. The functional, tagged proteins were detected and purified with the epitope-specific antibody.

Epitope tagging eliminates the laborious, time-consuming task of producing an antibody to the specific protein being studied. Unlike a large fusion protein, these small epitope tags generally have minimal, if any, effects on the biological function of the tagged protein. To determine whether the tag affected the biological function of the protein the strain, in which the protein was tagged, was tested for growth and resistens toward DNA damaging agents. If the tagged strain displays normal groth and similar resistance to DNA damaging agents like the untagged wild type strain then the tag does not affect the function of the protein. After a protein was tagged Haemagglutinin tag [202], a nonapeptide sequence (YPYDVPDYA) from residues 
98-106 of the hemagglutinin protein (HA1 protein), a surface glycoprotein required for the infectivity of the human influenza virus, was used in three copies.

\subsection{Yeast two-hybrid assay}

The MATCHMAKER GAL4 two-hybrid system (Clontech Laboratories Inc.) was used according to the manufacturer's instructions. The yeast strains pJ69-4A and HF7C were co-transformed with the bait and prey plasmids and plated on synthetic medium lacking leucine and tryptophan to select for the plasmids. To detect interactions co-transformants were transferred to selective media lacking leucine, tryptophan and histidine and media lacking leucine, tryptophan, histidine and adenine. To eliminate residual growth on selection media, since HIS3 has a leaky expression in many yeast strain, 3-amino-1,2,4-triazole (3AT) was added, a known inhibitor of the HIS3 gene product. The results from each combination represents the average of five to seven separate co-transformants assayed in triplicate.

\subsection{Quantitative assay of sensitivity to UV}

Yeast cultures grown overnight in YPD medium were counted under microscope, spread onto YPD plates at appropriate dilutions and irradiated with UV light $(254 \mathrm{~nm})$ for varying times to apply the specified dosage. Plates were incubated in the dark to avoid activation of photolyase and conseqvent repair (chapter 1.2.1). Colonies were counted after 3 days. All experiments were repeated at least three times, and relative survival was averaged.

\subsection{Qualitative assay of sensitivity to MMS}

Sensitivity to chemical mutagens was analyzed by serial dilutions. Methyl methanesulfonate (MMS, Sigma, M4016), was added to agar medium in various concentrations. Yeast cultures were counted under microscope, serial diluted and spotted onto those plates and grown at $30^{\circ} \mathrm{C}$ for 3 days.

\subsection{UV-induced mutagenesis}

Yeast cultures grown overnight in YPD medium were spread onto SC plates and SC plates without arginine (SC-arg) and SC plates without arginine but 
supplemented with $60 \mathrm{mg} / \mathrm{l}$ L-canavanine, a toxic analogue of arginine, at appropriate dilutions ( $1 \times 10^{7}$ cells on SC-arg and 200 cells on SC plates for plating viability) and irradiated with UV light $(254 \mathrm{~nm})$ for varying times to apply the specified dosage. Plates were incubated in the dark and colonies were counted after 5 days. UV-induced mutation frequencies in the $C A N 1$ locus were measured by estimating frequencies of can $1^{R}$ mutants in the surviving populations at a given UV dose, selected on synthetic medium without arginine containing $60 \mathrm{mg} / \mathrm{ml}$ canavanine. The arginine system enables detection of UV-induced $\mathrm{Arg}^{+}$revertants, of the arg 4-17 ochre allele. UVinduced mutation frequencies of the arg 4-17 ochre allele were measured by calculating the frequency of $\mathrm{Arg}^{+}$revertants in the surviving population at a given UV dose, selected on synthetic medium without arginine.

Standard deviations were calculated from triplicate measurements. All experiments were repeated independently $2-5$ times.

\subsection{MMS-induced mutagenesis}

Yeast cultures were grown in YPD medium to a final concentration of $2 \times 10^{7}$ cells $/ \mathrm{ml}$. Cells were centrifuged and resuspended in $600 \mu \mathrm{l}$ steril phosphate buffer (mixture of $40 \mathrm{ml} \mathrm{1M} \mathrm{K} 2 \mathrm{HPO}_{4}$ and $10 \mathrm{ml} 1 \mathrm{M} \mathrm{KH}_{2} \mathrm{PO}_{4}$ in $50 \mathrm{ml}$ final volume) (pH:7). $100 \mu \mathrm{l}$ cell culture was used for control. The remaining $500 \mu \mathrm{l}$ volume was supplemented with $500 \mu \mathrm{l}$ of $0,2 \% \mathrm{MMS}$ solution and incubated at $30^{\circ} \mathrm{C}$. At given time points $100 \mu \mathrm{l}$ samples were removed and neutralised with sterile sodium thiosulphate solution. Following serial dilution cells were plated onto YPD plates and grown at $30^{\circ} \mathrm{C}$ for $3-6$ days.

\subsection{Cell synchronization}

Cells were grown in YPD medium to $\mathrm{OD}_{600 \mathrm{~nm}}=0,600$ (or $5 \times 10^{6}$ cells $/ \mathrm{ml}$ ), then pelleted by centrifugation, washed with sterile water and resuspended in fresh YPD medium. To arrest the cells in the G1-phase of the cell cycle $50 \mathrm{ng} / \mathrm{ml}(30 \mathrm{nM}) \alpha 1$ Mating factor (Sigma T6901) was added for barl strains. $\alpha 1$-Mating Factor ( $\alpha$-factor) was stored as a $5 \mathrm{mg} / \mathrm{ml}$ stock in methanol at $-20^{\circ} \mathrm{C}$. Arrest of cells requires about 120 minutes in YPD at $30^{\circ} \mathrm{C}$. The degree of arrest was monitored by light microscopy starting at about 90 min after the addition of $\alpha$-factor. Small samples were taken and sonicated, then examined by microscopy. During the arrest protein synthesis is not 
affected and all cells that were past START when $\alpha$-factor was applied would divide. The full arrested population was collected by centrifugation, washed and resuspended in $1 \mathrm{x}$ PBS. Following irradiation with the indicated dose of UV light cells were collected by centrifugation, resuspended in fresh YPD medium and released from arrest with $50 \mu \mathrm{g} / \mathrm{ml}$ Pronase (Calbiochem 53702). All the strains used in these experiments were barl. After release cells were incubated at $30^{\circ} \mathrm{C}$ with shaking. Every $15 \mathrm{~min}$ at least two samples were taken and the pelleted samples were frozen in liquid nitrogen and stored at $-80^{\circ} \mathrm{C}$. For experiments where Pol3 polyubiquitination was investigated, the growth media always contained $100 \mu \mathrm{M} \mathrm{CuSO}_{4}$ to induce $7 \mathrm{His}-$ ubiquitin expression. $100 \mathrm{ml}$ cell culture was used as control. The remaing cell culture was collected by centrifugation and resuspended in 1XPBS and irradiated with $200 \mathrm{~J} / \mathrm{m}^{2} \mathrm{UV}$ light. Released cells were incubated at $30^{\circ} \mathrm{C}$ with shaking. Samples of $100 \mathrm{ml}$ culture were taken at given time points for whole cell extract preparation. Experiments employing MG132 (Sigma) were done in $p d r 5$ background to faccilitate the accumulation of MG132 in the cells. MG132 $(50 \mu \mathrm{M})$ was added to the $\alpha$-factor synchronized cultures 1 hour before UV irradiation. The rpn7-3 mutant and its isogenic wild type strain were grown at $25^{\circ} \mathrm{C}$. To detect the mutant phenotype we followed the protocol described [193]. Briefly, $100 \mathrm{ml}$ culture of logarithmically growing cells $\left(\mathrm{A}_{600}: 0.5\right)$ were split. Half of the culture was kept at $25^{\circ} \mathrm{C}$ and the other half was shifted to $37^{\circ} \mathrm{C}$. At $\mathrm{A}_{600}: 0.8$ cultures were synchronised by $\alpha$-factor for 3 hours and processed as detailed above.

\subsection{Protein tehniques- whole cell extract and western blotting}

Whole cell extracts were prepared by the trichloroacetic acid (TCA) protein purification method [201]. Cells from $-80^{\circ} \mathrm{C}$ (chapter 3.10) were thawn on ice and resuspended in $1 \mathrm{ml}$ cold MQ water. The cell suspensions were mixed with freshly

prepared $150 \mu \mathrm{l}$ freshly prepared $\mathrm{NaOH}(1.85 \mathrm{M})$ supplemented with $7.5 \% \quad \beta$ mercaptoethanol solution and placed on ice for $15 \mathrm{~min}$. Then $150 \mu \mathrm{l}$ of $55 \%$ TCA solution (stored in the dark) was added to the mixture, which was incubated for 20 min on ice. Cells were pelleted $\left(10 \mathrm{~min}\right.$ at $13000 \mathrm{rpm}$, at $\left.4^{\circ} \mathrm{C}\right)$ and the supernatant was removed. Following a second brief centrifugation all residual traces of TCA were aspirated off. Samples were washed with $1 \mathrm{ml}$ ice cold acetone $\left(-20^{\circ} \mathrm{C}\right)$ and pelleted $\left(1 \mathrm{~min}\right.$ at $13000 \mathrm{rpm}$, at $4^{\circ} \mathrm{C}$ ) again and the pellets were air-dried $\mathrm{O} / \mathrm{N}$. Dry pellets 
were resuspended in $45 \mathrm{mM}$ Tris- $\mathrm{HCl}$ and $1 \% \mathrm{SDS}$ (pH8.5). An aliquote of each sample was diluted 100 times and absorbance was measured at $260 \mathrm{~nm}$ and $280 \mathrm{~nm}$. Concentration of each sample was determined by using the following formula; Concetration $(\mathrm{mg} / \mathrm{ml})=(1.55 \times A 280)-(0.76 \times A 260)$. Protein concentrations were adjusted in 1xLaemmli buffer and $10 \mu 1$ of each sample was loaded onto $8 \%$ SDSpolyacrylamide gels [203]. Proteins were blotted onto nitrocellulose membrane at $300 \mathrm{~mA}$ for 3 hours followed by an $160 \mathrm{~mA} \mathrm{O} / \mathrm{N}$. Filters were probed with the following antibodies: a-HA (Gene Tex, GTX21208), anti-Clb2 (y-180) (Santa Cruz, sc-9071), anti-PGK (Molecular Probes, A-6457), Goat Anti-Mouse IgG (H+L) (Thermo Scientific, 31430), Goat Anti-Rabbit IgG (H+L) (Thermo Scientific, 31460).

\subsection{GST Fusion protein expression and pulldown assay}

POL31, POL32 and REV1 genes were cloned separately into pBJ842 plasmid in N-terminal fusion with GST, driven by GAL inducible promoter. The overexpression contructs were transformed into BJ5464 yeast strain and cells were grown in large scale for protein purification experiments.

Cells coresponding to 11 of saturated culture were ground with dry ice using a mortar and pestile, then resuspended in $1 \mathrm{XBS}$ buffer (TrisHCl pH 7; EDTA pH8; 3M $\mathrm{KCl}$; Sucrose; $150 \mathrm{mM} \mathrm{NaCl} ; \beta \mathrm{ME}$; protease inhibitor tablet (Roche).

After ultracentrifugation at 35,000 rpm for 90 minutes the clear lysates were transfered to columns packed with glutathione-Sepharose beads (Amersham Biosciences) and preequilibrated with $1 \mathrm{XBS}$ buffer. Following the binding step the columns were washed with high salt buffer (TrisHCl pH 7,5; $5 \mathrm{M} \mathrm{NaCl}$; glicerin; NP40) and with precision protease cleveage buffer (TrisHCl pH 7,5; EDTA pH8; 5M $\mathrm{NaCl}$ and; glicerin; NP40).

To obtain native proteins (e.g. Pol31 and Rev1) the beads with the bound GST tagged proteins were incubated $\mathrm{O} / \mathrm{N}$ with PreScission protease enzyme, which cleaves between the tag and the proteins, and pure proteins were collected. GST alone was also produced to use as a negative control in the assay.

In case of Rev1 purification the $1 \mathrm{XBS}$ buffer contains $1 \mathrm{M} \mathrm{NaCl}$ and after resuspension Triton- $\mathrm{X}$ was added to $0.1 \%$ final concentration and incubated at $4^{\circ} \mathrm{C}$ for 1 hour before ultracentrifugation to solubilise the protein. 
For complex formation, GST-Pol32 $(3 \mu \mathrm{g})$ immobilized on glutathioneSepharose beads was incubated $\mathrm{O} / \mathrm{N}$ on ice $\left(\right.$ at $\left.4^{\circ} \mathrm{C}\right)$ with purified Pol31 $(5 \mu \mathrm{g})$ and Rev1 $(3 \mu \mathrm{g})$, in buffer containing $50 \mathrm{mM}$ Tris/HCl, $\mathrm{pH}$ 7.5, $150 \mathrm{mM} \mathrm{NaCl}, 1 \mathrm{mM}$ EDTA, $1 \mathrm{mM}$ DTT, 10\% glycerol, 0.01\% Nonidet P-40. Beads were washed five times with the same buffer, and bound proteins were eluted in buffer containing 20 $\mathrm{mM}$ reduced glutathione. Various fractions were mixed with $2 \times$ Laemmli buffer containing $5 \% \beta$-mercaptoethanol, boiled for $5 \mathrm{~min}$ and analyzed by SDS/PAGE. 


\section{Results}

Several yeasts have been widely used as model organisms in genetics and modern cell biology research, largely because they are quick and easy to grow. Particularly Saccharomyces cerevisiae [204], "baker's" or "budding" yeast, is one of the most thoroughly researched eukaryotic microorganism. Researchers have used it to gather information about the biology of the eukaryotic cell and ultimately human biology. This strategy is made possible by the common descent of all living organisms, and the conservation of metabolic and developmental pathways and genetic material over the course of evolution. Studying model organisms can be informative, but care must be taken when extrapolating from one organism to another.

The cell cycle in yeast is very similar to the cell cycle in humans and is regulated by homologous proteins, likewise the protein complexes involved in the DNA damage bypass are highly conserved from yeast to humans that is why we chose Saccharomyces cerevisie as an in vivo model for our research.

\subsection{Genetic relations between $D E F 1$ and DNA damage tolerance genes}

Our main goal in this project was to find new genes that might affect the DNA damage bypass process and we decided to examine $D E F 1$ gene since it was known from the literature that deletion of $D E F 1$ rendered cells sensitive to UV-radiation, and the defl rad18 double deletion strain showed the same UV-sensitivity as the rad18 single mutant [162] suggesting an epistatic relationship, where the function of DEF1 was dependent on RAD18.

Epistasis analysis is a foundation in the analysis of genetic networks. The concept of epistasis was introduced nearly 100 years ago and today underpins our interpretation of genetic pathways [205]. If a mutation in one gene masks the phenotypic effects of a mutation in a second gene, then the first gene is said to be epistatic to the second [206].

In yeast two genes are in epistatic relationship if they affect the same pathway and by deleting them the sensitivity of the double deletion mutant to different agents (like DNA damaging agents, chemotherapeutic drugs, a.s.o) should not exceed that of the more sensitive single mutant, since both affect the same pathway. If two genes 
affect two different pathways then the double deletion mutant should have higher sensitivity than the individual single mutants because two pathways are blocked.

To explore the possibility that $D E F 1$ might be in an epistatic relationship with $R A D 18$, we analyzed the genetic relations between $D E F 1$ and members of all three branches (Fig. 8) of the RAD6-RAD18 pathway upon DNA damage. For this purpose we deleted the $D E F 1$ gene in different genetic backgrounds and the resulting strains were subjected to phenotypic analysis.

We determined the UV sensitivity of various mutants by measuring the survival rate of several genotypes following UV irradiation with different doses. We found the sensitivity of the defl rad6 double deletion strain did not exceed that of the rad6 single mutant. From this (Fig. 13, A) we concluded that the relationship between DEF1 and RAD6 is epistatic. Same result was obtained with RAD18 (Fig. 13, B) in agreement with the literature [162]. However, the def1 rad5 (Fig. 13, C), defl mms2 (Fig. 13, D) and the defl rad30 (Fig. 13, E) double deletion strains displayed much higher sensitivity to UV than any of the single mutants. This indicates that DEF1 is not epistatic with these genes and acts outside of the RAD30 or the RAD5, MMS2dependent sub-pathways. Nevertheless, the defl rev3 (Fig. 13, G) strain exhibited the same sensitivity as the defl mutant pointing to an epistatic relationship. Since Rev3 is the catalytic subunit of polymerase $\zeta$ we also checked the genetic relationship of DEF1 with REVI (Fig. 13, F), another polymerase of the REV3-mutagenic branch and REV7 (Fig. 13, H), the accessory subunit of Pol $\zeta$, and we obtained the same result since they all affect the same mutagenic branch of the RAD6-RAD18 pathway.

In conclusion, our data suggested that DEF1 participates in the REV3dependent mutagenic branch of the RAD6-RAD18 regulated DNA damage tolerance. 


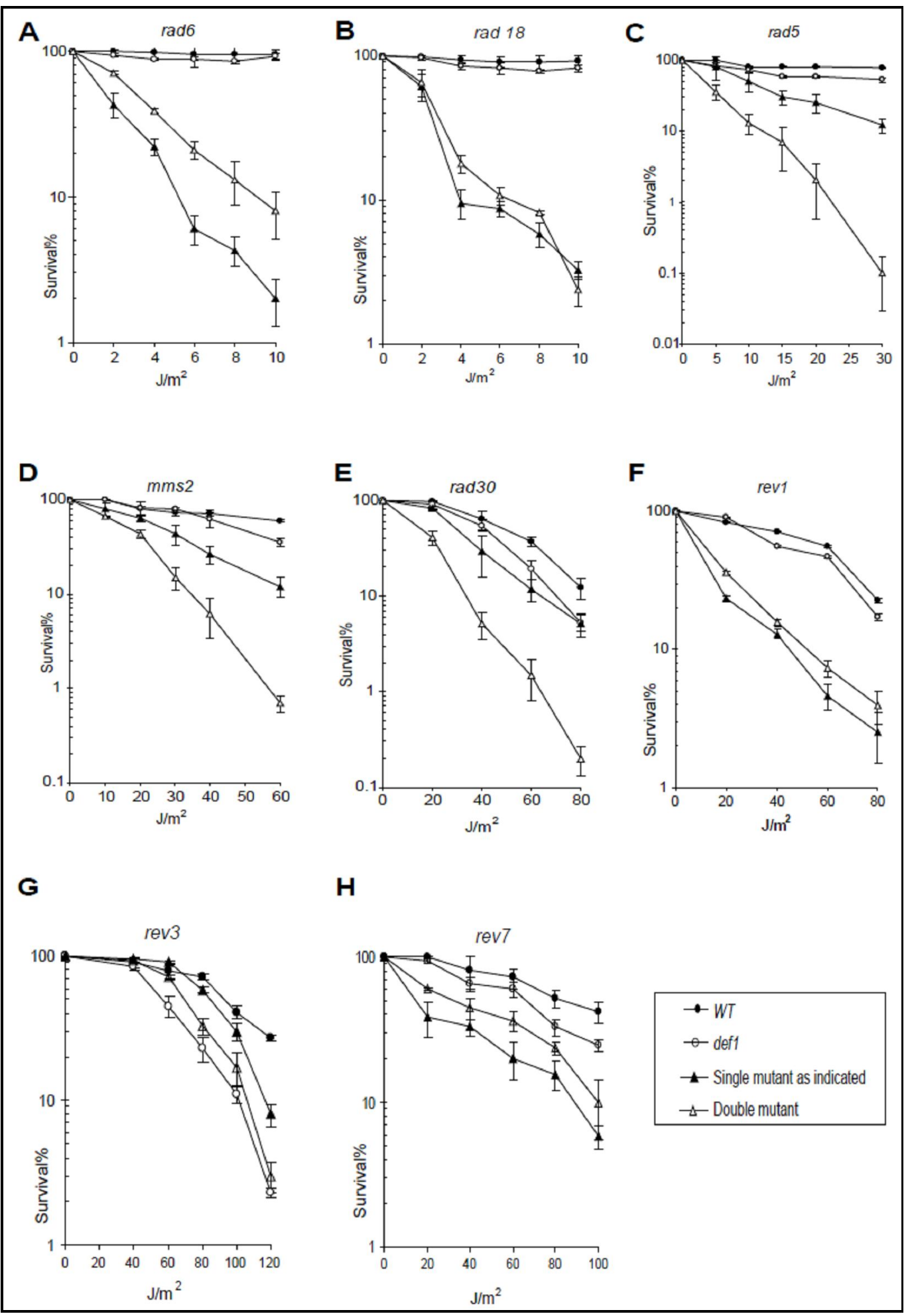

Figure 13 Genetic analysis of $D E F 1$ with mutants of different branches of the $R A D 6$ pathway upon UV-irradiation

Applied UV doses as well as standard deviations are indicated on each graph. All experiments were repeated three to five times, and relative survival was averaged. Different UV dose is applied for different strains due to their selective sensitivity. 
$\mathrm{UV}$ radiation is known to induce two of the most abundant mutagenic and cytotoxic DNA lesions such as cyclobutane-pyrimidine dimers (CPDs) and 6-4 photoproducts (6-4PPs) and their Dewar valence isomers [207]. To test whether other DNA damaging agents besides UV light classify DEF1 in the same pathway, we carried out similar experiments using methyl methanesulphonate (MMS) instead of $\mathrm{UV}$ as DNA damage source. MMS is an alkylating agent, which generates DNA methylated bases exhibiting cytotoxic and mutagenic properties. We have performed spot assays (Qualitative assays), where YPD plates were supplemented with various amounts of MMS and strains were serial diluted and spotted on these plates.

Upon MMS treatment def1 rad6 and def1 rad18 double deletion strains sensitivity to MMS did not exceed that of the rad6 and rad18 single mutant, supporting the epistatic relationship between DEF1 and RAD6 and RAD18 (Fig. 14, A and $14, \mathrm{~B})$. This means that $D E F 1$ plays role in the DNA damage bypass process controlled by Rad6-Rad18 complex. Similarly to the results obtained with UV, def1 rad5 (Fig. 14, C) and def1 mms2 (Fig. 14, D) double deletion strains displayed much higher sensitivity to MMS than any of the single mutants indicating that DEF1 acts outside of the RAD5, MMS2- dependent error-free sub-pathway of the RAD6/RAD18 group. Also DEF1 like in the case when UV was used as DNA damaging agent, showed epistasis with REV1 (Fig. 14, F), REV3 (Fig.14, G) and REV7 (Fig. 14, H) proving that it belongs to the REV3 dependent mutagenic branch of the RAD6-RAD18 controlled DNA damage bypass. 


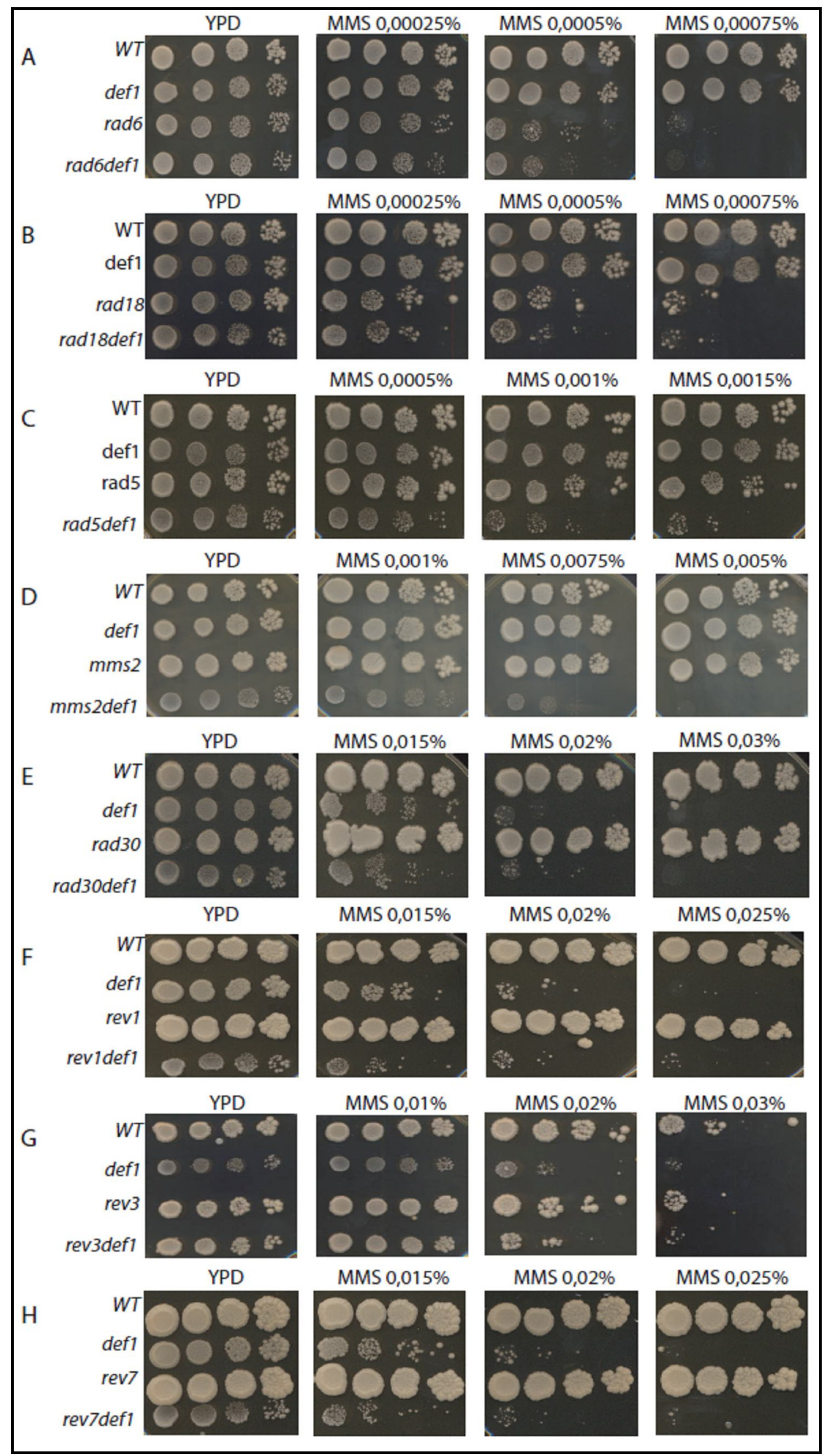

Figure 14 Genetic analysis of $D E F 1$ with mutants of the different branches of the $R A D 6$ pathway upon MMS treatment

Used MMS doses are indicated at the top of each panel. Plates were grown for 3-5 days and each experiment was repeated 5 times. 
Interestingly, $D E F 1$ showed epistasis with $R A D 30$, upon MMS treatment (Fig. $14, \mathrm{E})$ as the double mutant def1 rad30 was as sensitive to MMS as the defl single mutant, contrary to the UV results which clearly showed that $D E F 1$ acts outside of the $R A D 30$-dependent subpathway. To check whether this result reflects a real epistatic relationship and not only the insensitivity of rad30 to MMS, we performed further epistatic analyses where we checked the relationship between RAD30 and MMS2 and $R A D 30$ and REV3. Double deletion mutant rad30 mms2 was hypersensitive to MMS (Fig.15, A), underlying that RAD30 and MMS2 affect two different pathways of the RAD6-RAD18 controled DDT. However, both Rad30 and Rev3 are TLS polymerases and upon MMS damage they show epistasis (Fig.15, B) suggesting that in the bypass of MMS-induced DNA lesions, RAD30 works in the REV3 branch.

In conclusion, our data strongly suggest that $D E F 1$ participates in the REV3dependent mutagenic branch of the RAD6-RAD18 regulated DNA damage tolerance.

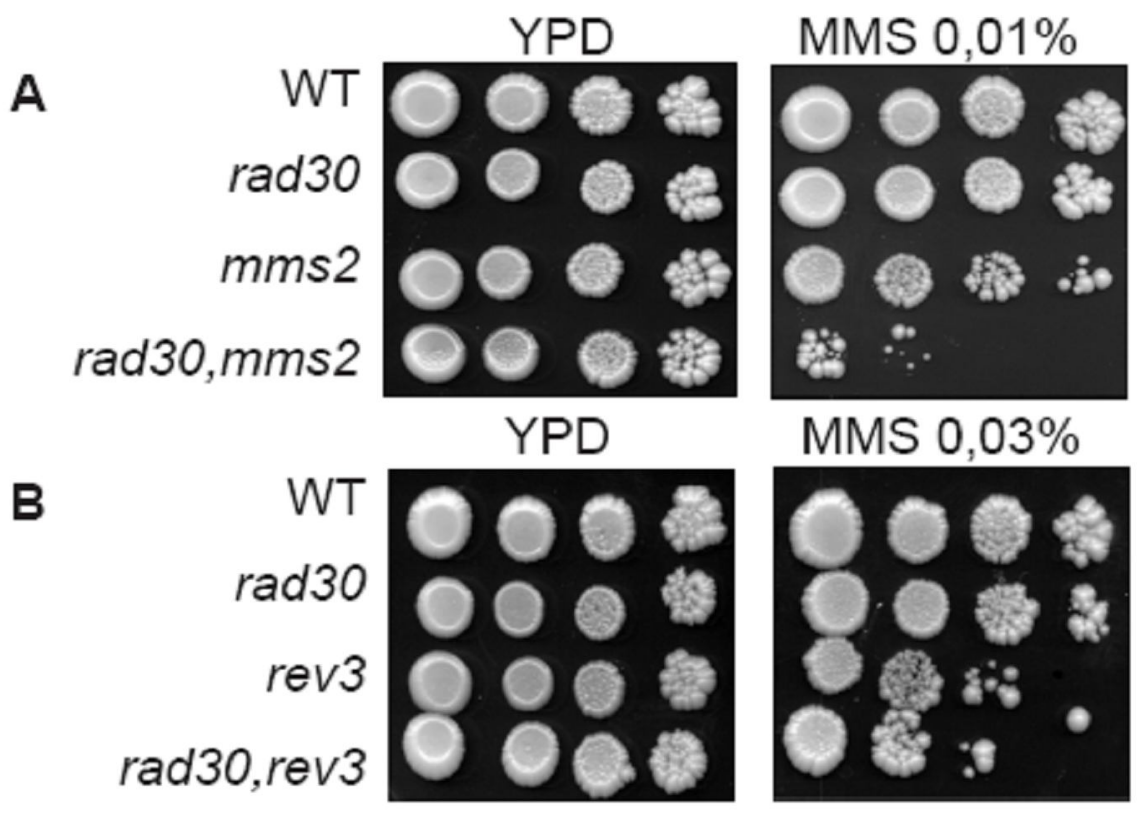

Figure 15 Genetic interactions of $R A D 30$ with $M M S 2$ and REV3 upon MMS treatment

Used MMS doses are indicated at the top of each panel. Plates were grown for 3-5 days and each experiment was repeated 5 times.

(A) The double mutant is much more sensitive, than any of the single mutants underlying that there is no epistasis between $R A D 30$ and $M M S 2$

(B) The double mutant shows same sensitivity as rev3, implying an epistatic relationship between $R A D 30$ and $R E V 3$. 


\subsection{Deletion of $D E F 1$ abolishes the UV and MMS-induced mutagenesis}

To confirm the results of the epistatic analysis we performed also a functional test. The TLS polymerases of the REV3 branch are responsible for virtually all damage-induced mutagenesis, and inactivation of either one causes a strong antimutator effect [208].

To verify that $D E F 1$ belongs to the REV3 branch, first we measured the rate of UV-induced mutations in defl strains using two selection systems: the "canavanine" and the "arginine system". The first one is based on the detection of forward inactivating mutations at the CAN1 locus (Fig. 8). The other method (Fig. 9) enables detection UV-induced $\mathrm{Arg}^{+}$revertants, of the arg 4-17 ochre allele.

In both experimental setups in the wild type strains there is a moderate increase in the mutation rate, with increasing UV doses, however defl showed a complete defect in induced mutagenesis (Fig. 16 and Fig. 17). In fact, defl was even more defective than the rev3 strain (Fig. 16), which is known to inhibit mutagenesis. In $m m s 2$ strain the mutation rate is very high, most probably because in the absence of the error-free branch, lesions are channeled to the REV3-dependent mutagenic pathway. Although given the high level of mutagenesis in mms 2 still deletion of $D E F 1$ prevented induced mutagenesis. Confirming that the immutability was in fact due to the absence of $D E F 1$, we introduced $D E F 1$ in the cells on a plasmid under the regulation of the ADH1 promoter. Indeed ectopic expression of DEF1 in defl cells restored the level of mutagenesis back close to wild type (Fig.16). Based on these results and in agreement with the results of the epistasis analysis, we concluded that $D E F 1$ participates in the REV3-dependent mutagenic branch of the RAD6/RAD18regulated DNA lesion bypass.

To strengthen these results, we carried out similar experiments using MMS instead of UV. Since MMS generates different types of DNA damage as compared to $\mathrm{UV}$-irradiation. In these experiments defl mutant proved to be completely defective in MMS-induced mutagenesis (Fig. 18). In summary we can conclude that DEF1 plays an essential role in induced mutagenesis regardless of the type of DNA damage stressor. 


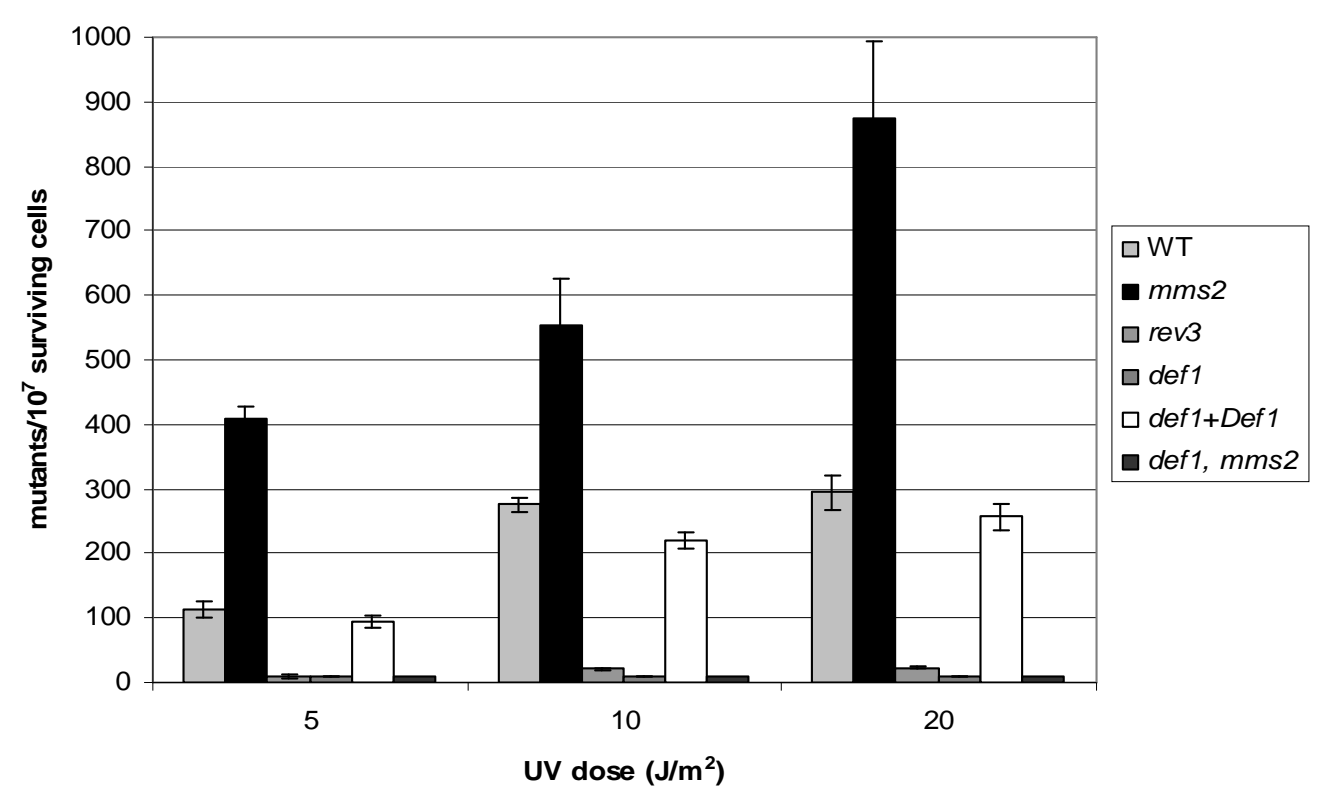

Figure 16 DNA damage-induced mutagenesis is abolished in def1 deletion mutants

Forward mutation rates at the CAN1 locus were determined after UV treatment. Where indicated, defl deletion was complemented by wild type DEF1 expressed under the control of the ADH1 promoter on a centromeric plasmid. The standard deviation is indicated above each bar. Experiments were repeated three times.

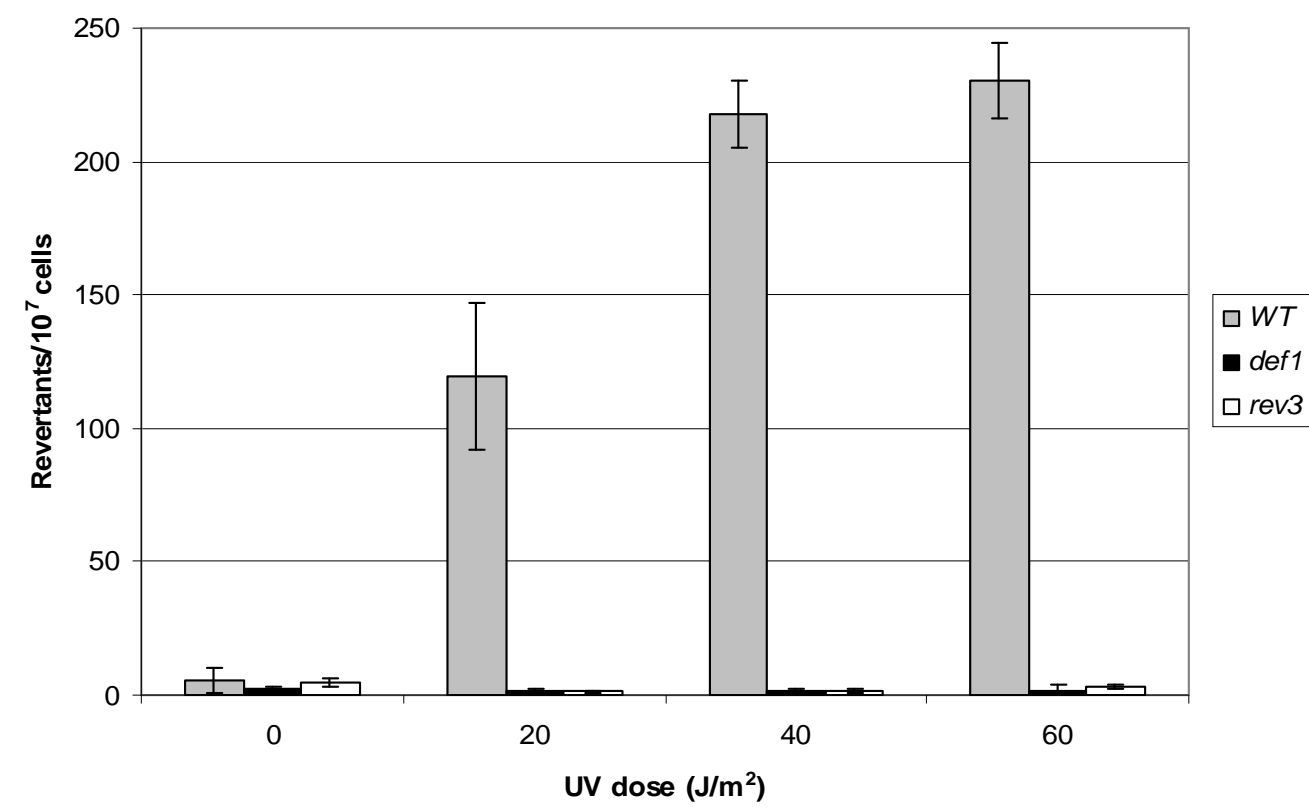

Figure $17 \mathrm{UV}$-induced mutagenesis is abolished in def1 deletion mutants Spontaneous and UV-induced $\mathrm{Arg}^{+}$revertants, of the $\arg 4-17$ ochre allele were detected after UV treatment. 


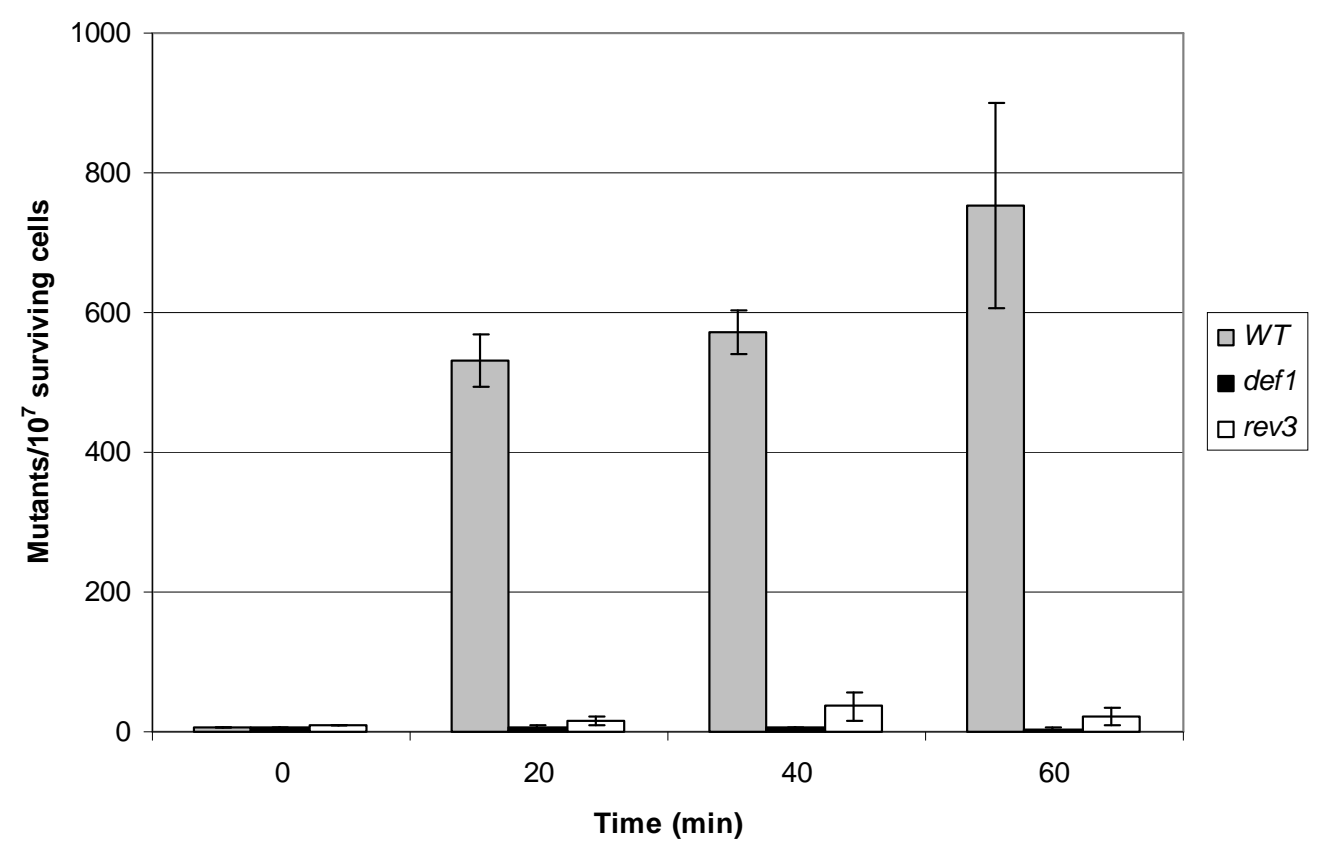

Figure $18 \mathrm{MMS}$ induced mutagenesis in def1 strain is abolished

Forward mutation rates at the CAN1 locus were determined after MMS treatment. Cells were treated with $0.02 \%$ MMS and at given time points samples were removed, serial diluted and plated on YPD plates. After three days colonies were counted. The standard deviation is indicated above each bar. Experiments were repeated three times and the results were averaged.

\subsection{Yeast two hybrid assays fail to identify Def1 interaction partners}

To further establish that DEF1 operates in the REV3 pathway, using yeast two hybrid assays, we examined the interaction of Def1 with TLS polymerases from the mutagenic and error- free branches, respectively. We used two selection steps, one specific for the detection of weak protein-protein interactions (Table 2, panel 2) and another more stringent specific for detection of strong protein-protein interactions (Table 2, panel 3). However Def1 presented self-activation and the intensity level of all the other interactions did not exceed that of Def1's self-activation, we concluded that no interaction can be detected between Def1 and any of the TLS polymerases using yeast two hybrid assays.

Then we checked whether there is any interaction between Def1 and other members of the RAD6-RAD18 pathways. Inspite of all the efforts with yeast two hybrid assays we could not detect an interacting partner for Def1, not even in the presence of DNA damaging agents like MMS or UV since Def1 is known to act under 
damage. We concluded that Def1 interactions can not be examined with yeast two hybrid systems.

\begin{tabular}{|r|r|r|r|r|r|r|}
\hline \multicolumn{2}{|c|}{ Panel 1 (-LEU-TRP) selection } \\
\hline & BD & Def1-BD & Rad5-BD & Rad30-BD & Rev1-BD & Rev7-BD \\
\hline AD & + & + & + & + & + & + \\
\hline Def1-AD & + & + & + & + & + & + \\
\hline Rad5-AD & + & + & + & + & + & + \\
\hline Rad30-AD & + & + & + & + & + & + \\
\hline Rev1-AD & + & + & + & + & + & + \\
\hline Rev7-AD & + & + & + & + & + & + \\
\hline
\end{tabular}

Panel 2 (-LEU-TRP-HIS) selection for weak protein-protein interactions

\begin{tabular}{|r|r|r|r|r|r|r|}
\hline & BD & Def1-BD & Rad5-BD & Rad30-BD & Rev1-BD & Rev7-BD \\
\hline AD & - & - & - & - & - & + \\
\hline Def1-AD & + & - & + & - & + & + \\
\hline Rad5-AD & - & - & - & - & - & - \\
\hline Rad30-AD & - & - & - & - & - & - \\
\hline Rev1-AD & - & - & - & - & - & - \\
\hline Rev7-AD & - & - & - & - & - & - \\
\hline
\end{tabular}

Panel 3 (-LEU-TRP-HIS-ADE) selection for strong protein-protein interactions

\begin{tabular}{|r|r|r|r|r|r|r|}
\hline & BD & Def1-BD & Rad5-BD & Rad30-BD & Rev1-BD & Rev7-BD \\
\hline AD & - & - & - & - & - & + \\
\hline Def1-AD & + & - & - & - & - & + \\
\hline Rad5-AD & - & - & - & - & - & - \\
\hline Rad30-AD & - & - & - & - & - & - \\
\hline Rev1-AD & - & - & - & - & - & - \\
\hline Rev7-AD & - & - & - & - & - & - \\
\hline
\end{tabular}

Table 2 Checking the interaction of $D E F 1$ with members of $R A D 6-R A D 18$ pathway with yeast two hybrid systems

."+" indicates the positive interaction, "-"indicates the absence of interaction. AD (Activating Domain vector), BD (Binding Domain vector)

\subsection{Pol3 is degraded upon DNA damage by a Def1-dependent manner}

Our genetic studies placed DEF1 in the REV3 branch of the RAD6-RAD18 pathway. Next we examined the role of DEF1 in the mutagenic pathway. Unlike other members of the REV3 branch, Def1 protein lacks the domains characteristic to a polymerase and does not show DNA polymerase activity. One of its known functions from the literature [162] is to advance the removal of the stalled RNA polymerase by facilitating its proteolytic degradation upon transcriptional blockage due to DNA damage. We surmised that it might play a similar role in replication and promote the removal of the replicative polymerase from the stalled replication fork, thereby 
facilitating the exchange between the TLS and the replicative polymerases at DNA damage sites.

As Def1 played role in the ubiquitination of stalled RNA polymerase II [162], it is possibile that similarly it could efficiently mediate ubiquitination of the stalled replicative DNA polymerase. Ubiquitination then could lead to polymerase switch by either playing a regulatory role as in case of DNA damage-induced ubiquitination of PCNA [80], or it could result in protein removal through degradation. To test these possibilities, we followed the fate of replicative polymerase during DNA damage bypass by monitoring the protein level of the HA-tagged Pol3, the catalytic subunit of the replicative DNA polymerase $\delta$ during cell cycle. The $\alpha$-factor synchronized yeast culture was UV treated with the indicated UV doses and samples were taken at the indicated time points after release from G1 phase (Fig. 19). For these experiments we have used a barl yeast strain. With a barl strain, the length of time at the arrest is less critical than with a $B A R l$ strain in which cells will continuously degrade $\alpha$-factor and are likely to recover from the arrest on their own. The barl strain synchronises better then a $B A R l$ strain and requires less $\alpha$-factor.

In order to facilitate translesion synthesis, we first used an mms 2 deletion strain. Importantly, we observed that increasing UV doses result in more pronounced, but transient decrease in the level of Pol3 compared to normal growth conditions. (Fig. 19). 


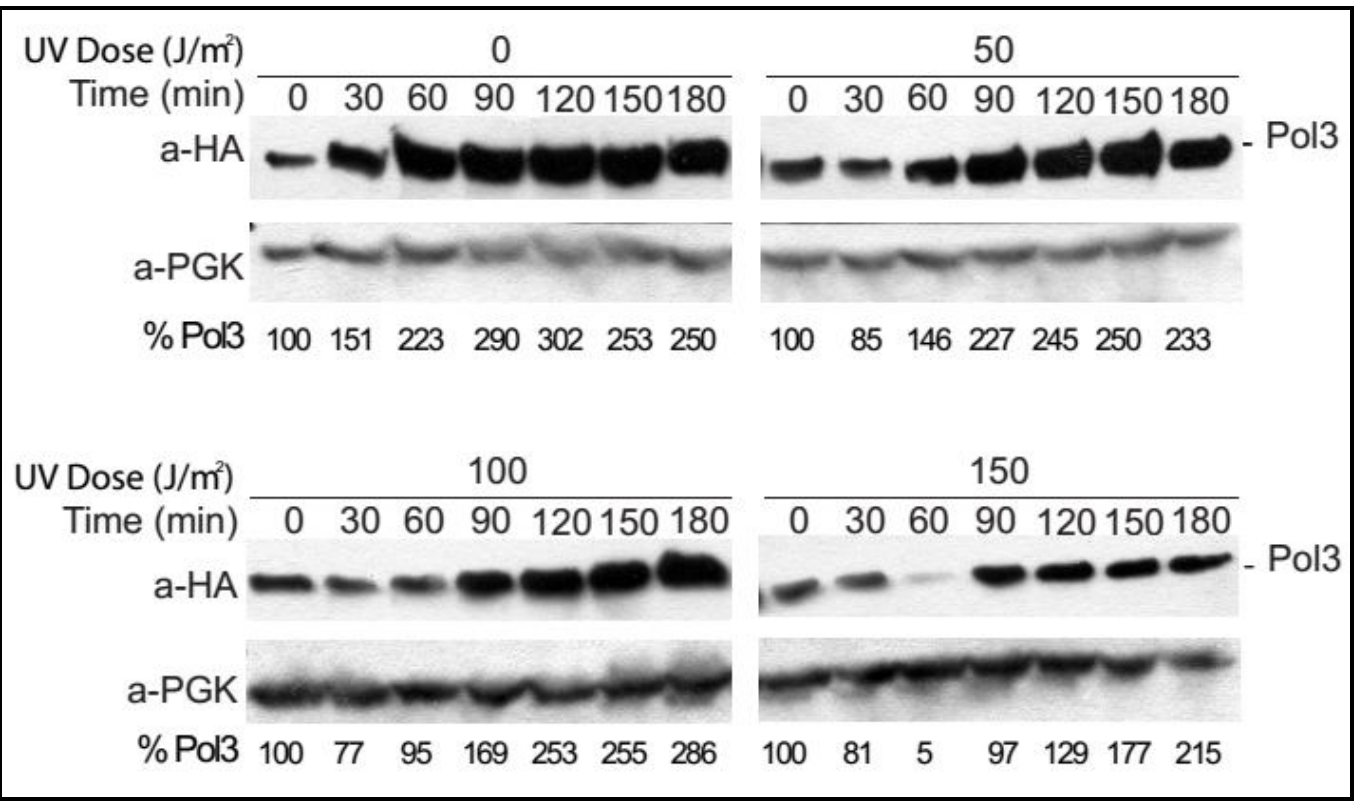

Figure 19 The effect of increasing UV doses on the level of Pol3

Proteins from whole cell extracts were analyzed by western blotting. HA-tagged Pol3 was visualized in whole cell extracts by anti HA antibody. PGK was used as a loading control

To check whether the decrease in the level of Pol3 upon UV-irradiation is Def1 dependent we followed the faith of Pol3 in different mutant backgrounds. As opposed to normal growth conditions, we could also detect upon UV-irradiation a transient decrease in the level of Pol3 in wild type cells. The decrease was visible in the $\mathrm{S}$ phase of the cell cycle, as indicated by the expression pattern of the cyclin dependent Clb2, which appears in the G2/M phase of the cell cycle (Fig. 20, A).

Importantly, in experiments using a defl deletion strain we could not detect decrease in the level of Pol3 (Fig. 20, B). To investigate whether the observed phenomenon was ultimately under the higher control of $R A D 6$, we performed the same experiment in a rad6 strain. Similarly to the result obtained in the defl strain we found that Pol3 diminution was absent in rad6 mutants (Fig. 20, C). On the other hand, reduction of Pol3 could be seen in mms2 (Fig. 20, D) and also in rad30 (Fig. 20, E) backgrounds. These results, in view of the genetic relations between $D E F 1$ and members of the RAD6 group, strongly imply that the observed effect on Pol3 is dependent on $D E F 1$, which exerts this function within the RAD6-dependent mutagenic DNA damage bypass pathway. 


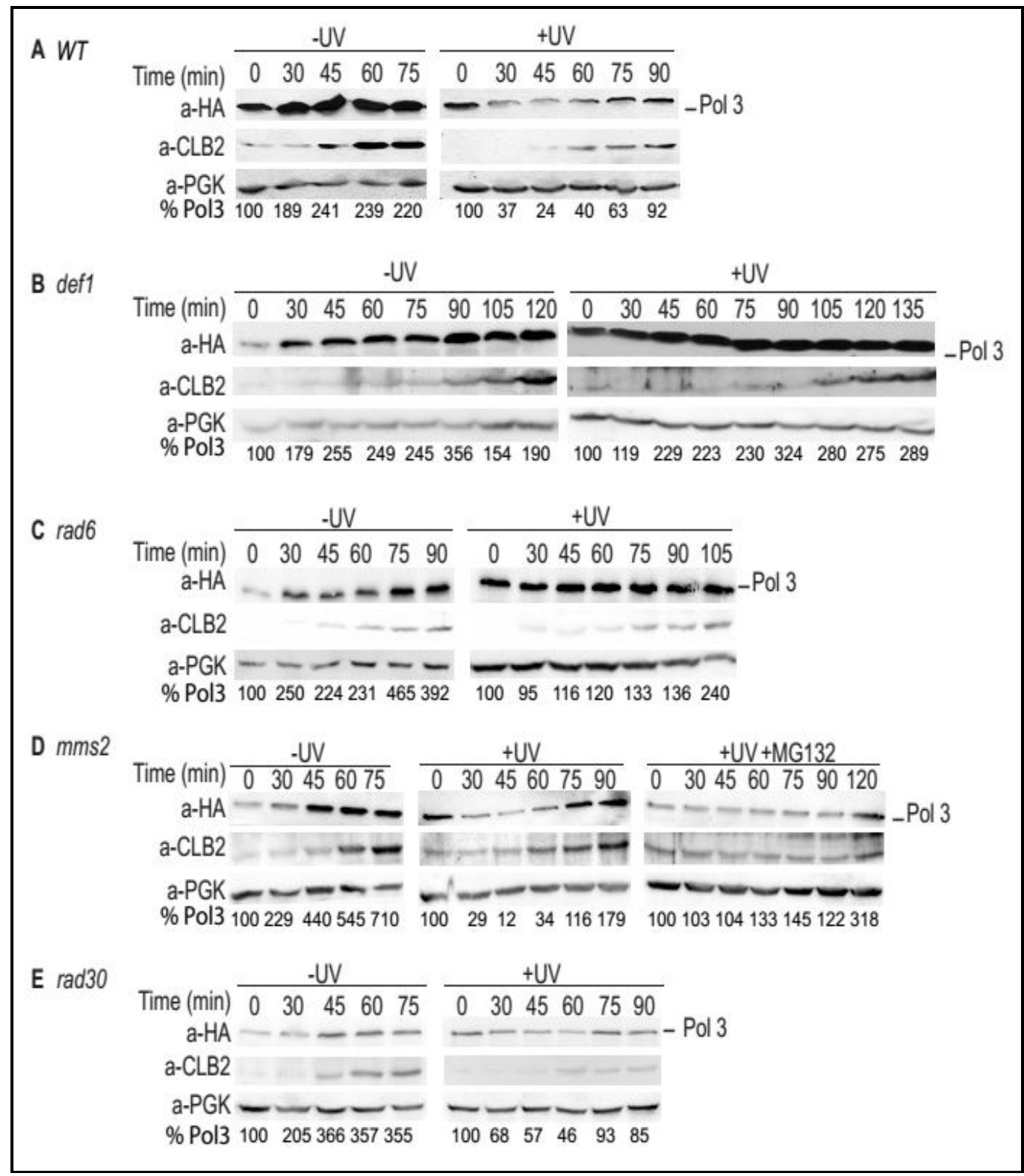

Figure 20. UV Induced degradation of Pol3 in different mutants

Cultures were synchronized by $\alpha$-factor, UV-irradiated with $150 \mathrm{~J} / \mathrm{m}^{2}$ and released back to growth media. Proteins from whole cell extracts, prepared from cells collected at the indicated time points after UV treatment, were analyzed by western blotting. Anti-HA antibody was used to detect HA tagged Pol3 (A to E). Cell cycle stages were monitored by $\mathrm{Clb} 2$ cyclin levels, and PGK served as a loading control. Proteasome inhibitor MG132 $(50 \mu \mathrm{M})$ was added to the $\alpha$-factor synchronized cultures 1 hour before UV irradiation (D). 


\subsection{Def1 induces the ubiquitination and proteasomal degradation of Pol3}

The most plausible explanation for the transient decrease of Pol3 would be that Pol3 underwent regulated protein degradation induced by UV. The majority of regulated proteolysis takes place in the proteasome in eukaryotic cells. To resolve whether the decrease in the Pol3 protein level was due to protein degradation mediated by the proteasome, we inactivated the proteasome by supplementing the growth media with a proteasome inhibitor (MG132). Indeed, in the presence of MG132, the UV-induced degradation of Pol3 could not be observed (Fig. 20, D).

To add further evidence, we have repeated the experiment using a temperature sensitive proteasome mutant strain $r p n 7-3$. It has been published that Rpn7 is one of the lid subunits of the $26 \mathrm{~S}$ proteasome regulatory particle and the RPN7 gene is essential [193]. All the temperature sensitive $r p n 7$ proteasome mutants accumulated poly-ubiquitinated proteins when grown at the restrictive temperature, indicating a temperature sensitive ubiquitin-proteasome pathway [193]. Using the rpn7-3 mutant we could not detect Pol3 degradation at the restrictive high temperature $\left(37^{\circ} \mathrm{C}\right)$, where the proteasome was not functional, contrary to the permissive low temperature $\left(25^{\circ} \mathrm{C}\right)$, where the actively functioning proteasome degraded Pol3 (Fig. 21, B). Meanwhile in the wild type RPN7 strain, degradation occurred at both temperatures (Fig. 21, A). These results demonstrated that the proteasome was responsible for the UV-induced degradation of Pol3.

Ubiquitination is a major signal for proteasomal protein degradation. To show ubiquitination of Pol3, we introduced a plasmid which expressed an N-terminally 7 histidine tagged ubiquitin from a $\mathrm{CuSO}_{4}$ inducible promoter in yeast cells. After induction with $\mathrm{CuSO}_{4}$, cells were arrested with $\alpha$-factor for 4 hours. The culture was irradiated with $150 \mathrm{~J} / \mathrm{m}^{2}$ UV light. After cells were released from arrest samples were removed at given time points. Ubiquitylated proteins prepared from cell extracts were enriched on nickel beads. Small amounts from the extracts before adding to the beads were run on separate gels to check the input of Pol3 and PGK was used as loading control. Also the level of ubiquitilation was checked to eliminate the possibility that poly-ubiquitilated forms of Pol3 are not visible in the def1 and rad6 strains because of alteration in ubiquitin expression. Indeed in the bound fraction we could detect polyubiquitylated forms of Pol3 upon UV-irradiation in wild type cells, but not in defl and 
rad6 cells (Fig. 22). This result confirmed that Def1 assists Pol3 poly-ubiquitination upon DNA damage.

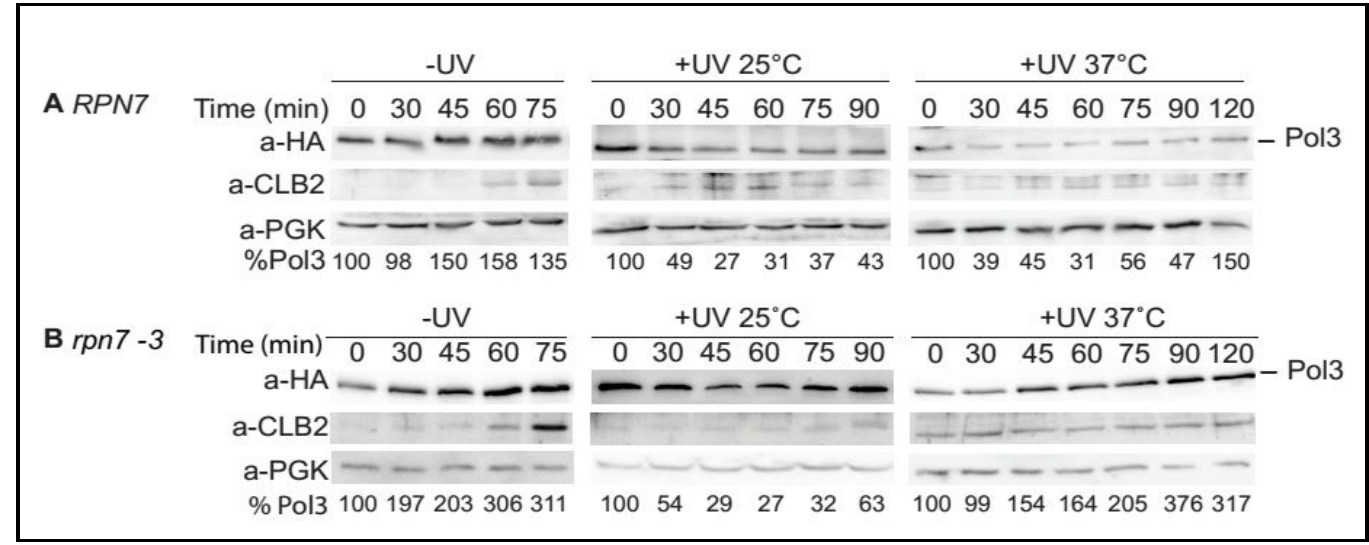

Figure 21 Pol3 UV-induced degradation is mediated by the proteasome

(A) In the wild type RPN7 strain, degradation of Pol3 occurres at both temperatures (B) The rpn7-3 mutant is deficient in degrading Pol3. Experiments were done as described in Figure 12, except for inactivation of the proteasome cells were shifted to $37^{\circ} \mathrm{C} 2$ hours before $\alpha$ factor treatment, and after 3 hours of synchronization, irradiated with $200 \mathrm{~J} / \mathrm{m} 2$. Anti-HA antibody was used to detect HA tagged Pol3. Cell cycle progression was monitored by $\mathrm{Clb} 2$ cyclin levels, and PGK served as a loading control. The level of Pol3 relative to PGK is shown at the bottom of each panel.

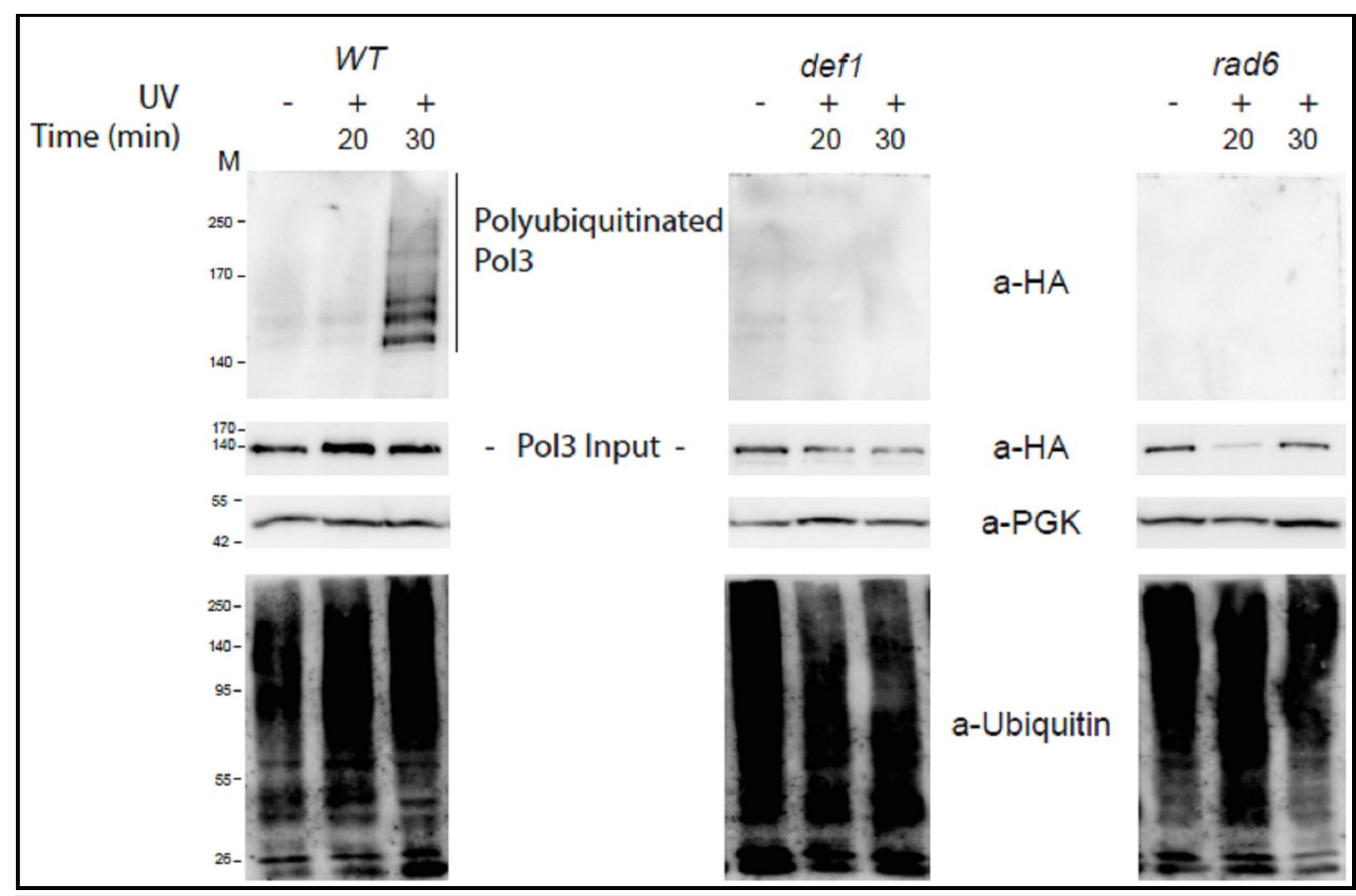

Figure 22 Def1 assists Pol3 poly-ubiquitination

Poly-ubiquitylated proteins from cell extracts prepared from $100 \mathrm{ml}$ of cell culture were bound to NiNTA agarose (Qiagen) and Pol3 was identified in the bound fraction with HA antibody (upper panels). The PGK and Pol3 levels in the extracts before adding to the beads are also shown, and the bound fraction was probed with anti-ubiquitin antibody (lower panels). The applied UV dose was $150 \mathrm{~J} / \mathrm{m}^{2}$. 


\subsection{Pol31 and Pol32 are not subject to UV-induced degradation}

Pol $\delta$ is a heterotrimer and consists of two additional non-catalytic subunits, Pol31 and Pol32, besides Pol3 [209]. Pol31, like Pol3, is essential for cell viability, but Pol32 is a non-essential subunit. Pol3 forms a stable complex with Pol31, and Pol32 is attached to this complex through its interaction with Pol31 [210].

We examined whether the whole Pol $\delta$ enzyme is subjected to UV-induced proteolysis, or it affects only the catalytic subunit. We performed similar experiments as described in Chapter 4.4 and shown in Fig. 20, but in this chase Pol31 and Pol32, the accessory subunits of Pol $\delta$ were chromosomaly tagged with 3- HA tag and we followed their fate in an $\alpha$-factor synchronized yeast culture upon UV damage.

We found that contrary to Pol3, which is degraded Pol31 and Pol32 were not affected by UV-induced degradation (Fig. 23, A and B), since no decrease on the level of Pol31 orPol31 could be detected after UV treatment.

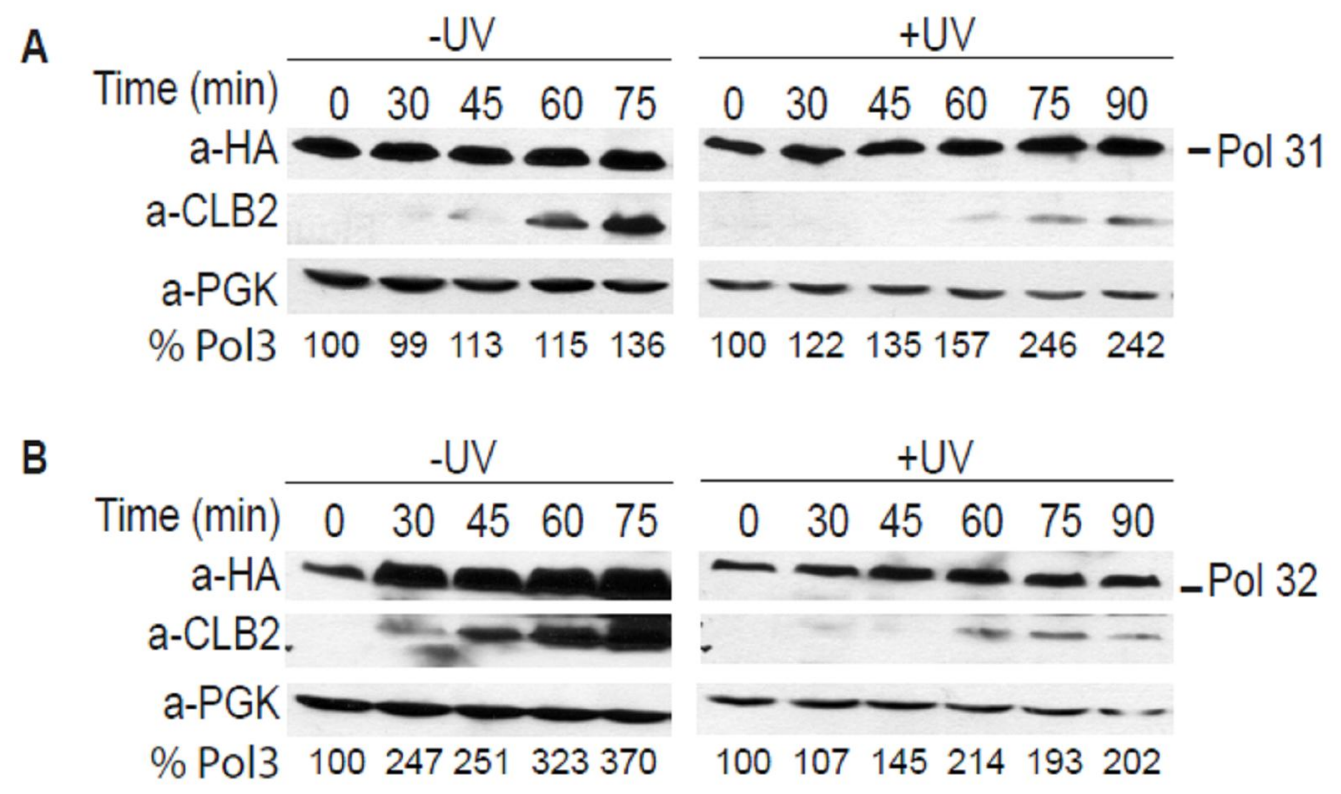

Figure 23. Pol31 and Pol32 were not affected by UV-induced degradation Proteins from whole cell extracts, prepared from cells collected at the indicated time points after UV treatment, were analyzed by western blotting. Anti-HA antibody was used to detect HA tagged Pol31 (A), or Pol32 (B). Cell cycle stages were monitored by Clb2 cyclin levels, and PGK served as a loading control. The applied UV dose was $150 \mathrm{~J} / \mathrm{m}^{2}$. 


\subsection{In vitro complex formation between Pol31, Pol32 and Rev1}

Taken together these results suggested that during DNA damage bypass since Pol31 and Pol32 are not affected by UV-induced degradation, they remain at the stalled fork, where they protect the fork mantaining its integrity. We postulated that a TLS polymerase, like Rev1 could take the place of Pol3 and carry out lesion bypass in complex with Pol31 and Pol32. To test this idea, we examined whether Pol31 and Pol32 together could form a complex with Rev1 in in vitro assays using purified proteins (Fig. 24, A). We chose Rev1, because it had been suggested to function as a

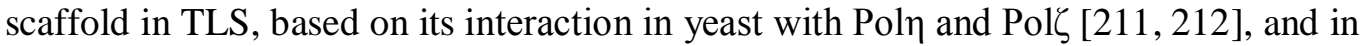

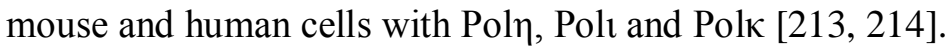

In a glutathione S-transferase (GST) pull-down assay we added Pol31 and Rev1 to GST-Pol32 immobilised on glutathione-Sepharose affinity beads, and after incubation bound proteins were released from the beads by glutathione. As shown in Figure 24, B, lane 4, both Pol31 and Rev1 eluted together with GST-Pol32, indicating that these proteins formed a complex together. In contrast, in a control experiment using GST instead of GST-Pol32, only GST was present in the elution fraction confirming that the interaction between Pol31, Pol32 and Rev1 was specific.

In conclusion, purified Pol31, Pol32 and Rev1 could interact directly and form a stable multi-subunit protein complex.

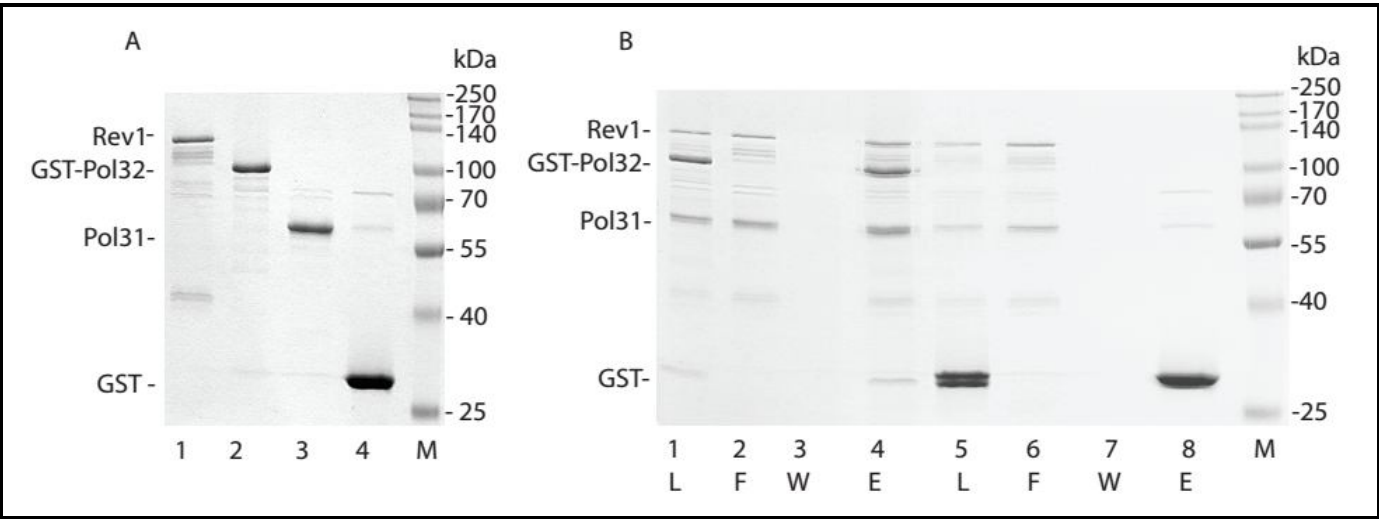

Figure 24 Rev1 forms a complex with Pol31 and Pol32

(A) Purified proteins. GST-Pol32 (lane 2), Pol31 (lane 3), Rev1 (lane 1) and GST (lane 4) were run on 10\% SDS-polyacrylamide gel. (B) GST pull-down of Pol32 with Pol31 and Rev1. GST-Pol32 immobilized on glutathione-Sepharose beads was incubated with purified Pol31 and Rev1. After washing, bound proteins were eluted with glutathione. Aliquots of each sample, taken before addition to the beads (L), from the flow-through fraction $(\mathrm{F})$, from the last wash $(\mathrm{W})$, and from the glutathione-eluted proteins (E), were analyzed on 10\% SDS-polyacrylamide gel (lanes 1-4). The results for the control experiment using GST instead of GST-Pol32 are shown in lanes 5-8. 


\section{Discussion}

All organisms need to deal with the problems that arise when a moving replication fork encounters damage in the template strand. Obviously the best way to deal with this situation is to repair the damage by one of the excision mechanisms. In some cases, however, the damage may not be repairable, or the advancing replication fork may already have unwound the parental strands, thus preventing excision mechanisms from using the complementary strand as template for repair, or excision repair may not yet have had an opportunity to repair the damage. There are two reasons why it is important for the cell to be able to move replication forks past unrepaired damage. First, long-term blockage of replication forks leads to cell death. Second, replication of damaged DNA provides a sister chromatid that can be used as template for subsequent repair by homologous recombination. Replication fork bypass mechanisms cannot, strictly speaking, be considered examples of DNA repair, because the damage is left in the DNA, at least temporarily. Nevertheless, experiments in yeast demonstrate that damage bypass is an important component of the overall cellular response to DNA damage. It contributes to cellular survival of radiation damage to roughly the same extent as the pathways for nucleotide excision repair and repair by homologous recombination.

Eukaryotic mechanisms for replication fork bypass of damaged sites in DNA are not as well understood, they have been studied most extensively in the budding yeast, Saccharomyces cerevisiae. Genetic studies in the yeast have indicated that Rad6-Rad18 complex controls the bypass of UV-damaged DNA via at least three separate pathways through the ubiquitilation of PCNA: an error-free pathway dependent on the RAD5, MMS2 and UBC13 genes, another error free pathway dependent on the RAD30 gene, and a third pathway that is mutagenic and dependent on the REV1, REV3 and REV7 genes [215].

Since Rad6-Rad18 complex is indispensable for the function of all three DNA damage pathways the question was what would be the mechanism through which Rad6-Rad18 regulates these pathways. To better understand how DNA damage bypass functions our main goal was to search for additional factors that affect this process.

For this purpose we chose to examine the $D E F 1$ gene since from the literature it was known that deletion of DEF1 renders cells sensitive to UV-radiation, and the 
def1 rad18 double deletion mutant shows the same UV-sensitivity as the rad18 single mutant [162]. Contrary to the authors conclusion we wanted to examine whether this result could reflect an epistatic relationship, where the function of $D E F 1$ is dependent on $R A D 18$.

The genetic analysis between $D E F 1$ and members of all three branches of the $R A D 6$ pathway upon DNA damage has shown that DEF1 is epistatic to RAD6 and $R A D 18$ and shows no epitasis with members of the error-free pathways like RAD5, $M M S 2$, and $R A D 30$, indicating that $D E F 1$ acts outside of error-free pathways of the PRR. Nevertheless, $D E F 1$ shows epistasis with REV3 indicating that $D E F 1$ belongs to the REV3 branch of the RAD6-RAD18-dependent DNA damage tolerance pathway (Fig.25), where it plays an indispensible role during induced mutagenesis. We wanted to check with yeast two hybrid whether Def1 ineracts with TLS polymerases, but we could not detect any interactions. We have also performed these experiments in the presence of DNA damaging agents like, MMS and UV. Despite all our efforts we could not detect any interactions so we concluded that either there is no interaction between the examined proteins or Def1 can not be examined with yeast two hybrid systems.

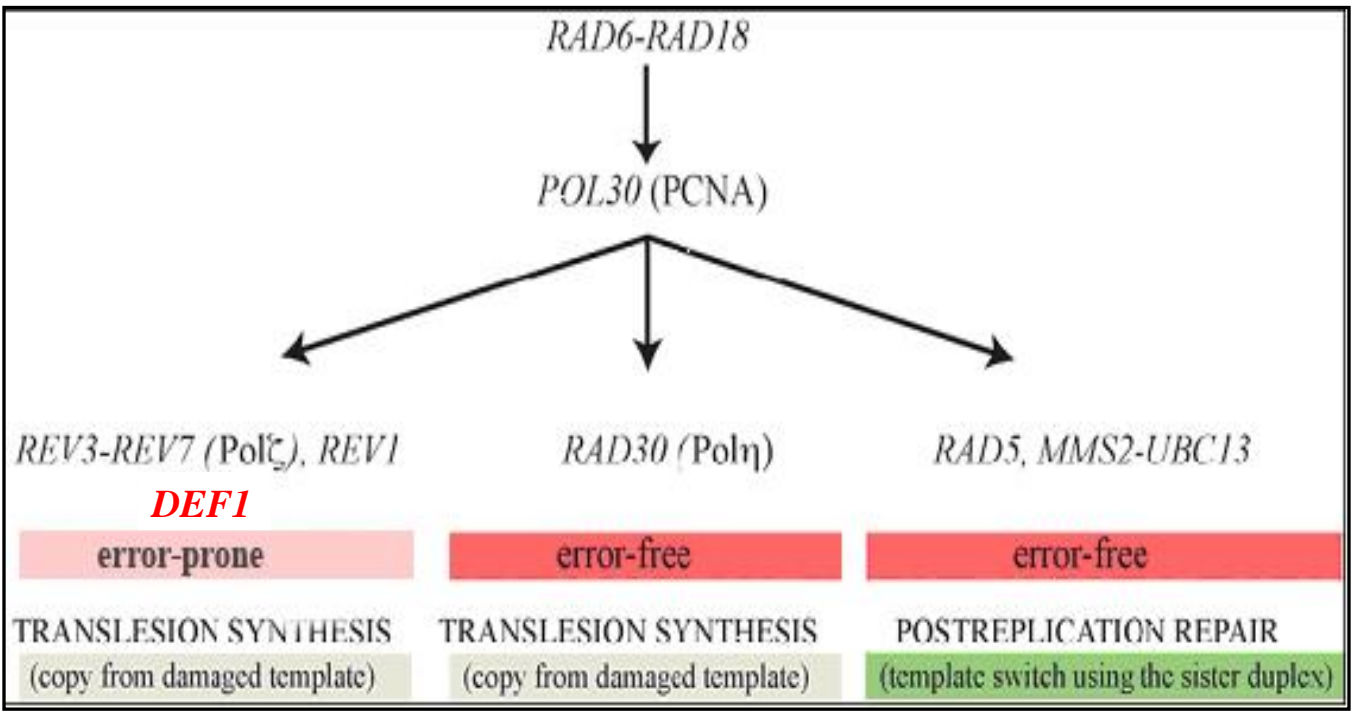

Figure 25 Def1 in the $R A D 6-R A D 18$ dependent damage tolerance pathway The Rad6-Rad18 governs at least three ways of replication of UV-damaged DNA through the ubiquitination of PCNA. (Adapted from Unk I. et al, 2010, DNA Repair) 
Damage-induced mutagenesis mostly arises from the activity of translesion synthesis polymerases during the bypass of replication blocking DNA lesions. However, the mechanism that allows the replacement of the replicative polymerase at stalled replication forks is unknown. Our genetic studies clearly place $D E F 1$ in the REV3 branch of the RAD6-RAD18 pathway.. Unlike other members of the REV3 branch, Def1 is not a DNA polymerase and from the literature it is known that one its functions is to advance the removal of the stalled RNA polymerase by facilitating its proteolytic degradation, when transcription is blocked due to DNA damage. We surmised that it might play a similar role in replication and promote the removal of the replicative polymerase from the stalled replication fork, thereby facilitating the exchange between the TLS and the replicative polymerases at DNA damage sites.

In order to establish the function of Def1 in the mutagenic branch we followed the fate of the replicative polymerase during DNA damage bypass by monitoring the protein level of Pol3, the catalytic subunit of the replicative DNA polymerase $\delta$ during cell cycle. We established that Pol3 was degraded upon UV-irradiation. We presented evidence that degradation of Pol3 was the result of polyubiquitination mediated proteosomal degradation, and it was dependent on DEF1 under the higher control of RAD6. Conversely, Pol31 and Pol32, the other two subunits of Pol $\delta$ were not degraded. We also demonstrated that Pol31 and Pol32 together could form a stable complex with TLS polymerase Rev1.

Our data imply that translesion synthesis polymerases carry out DNA lesion bypass in complex with Pol31 and Pol32, only after the Def1- assisted removal of Pol3 from the stalled replication fork.

Based on these results we propose a new model for polymerase exchange at stalled replication forks (Fig. 26). During replication, when Pol $\delta$ stalls at a DNA lesion, PCNA gets ubiquitinated by Rad6/Rad18. Mono-ubiquitinated PCNA activates the mutagenic pathway where, for translesion synthesis to occur, Pol3 is ubiquitinated by a Def1-dependent manner and removed from the stalled Pol $\delta$ complex through proteasome-mediated protein degradation. A TLS polymerase takes over the place of Pol3 and teams up with the remaining Pol $\delta$ subunits, Pol31 and Pol32, at the stalled fork to form a new complex capable of executing DNA lesion bypass. We surmise that after lesion bypass and deubiquitination of PCNA, the TLS polymerase is removed from the primer terminus, Pol3 restores Pol $\delta$ by regaining its place, and replication continues. Importantly, this finding also gives an explanation for previous 
genetic results showing that in pol32 cells induced mutagenesis is severely impaired, and that deletion of the N-terminal part of Pol32, responsible for binding Pol31, also abolish induced mutagenesis [209, 216, 217].

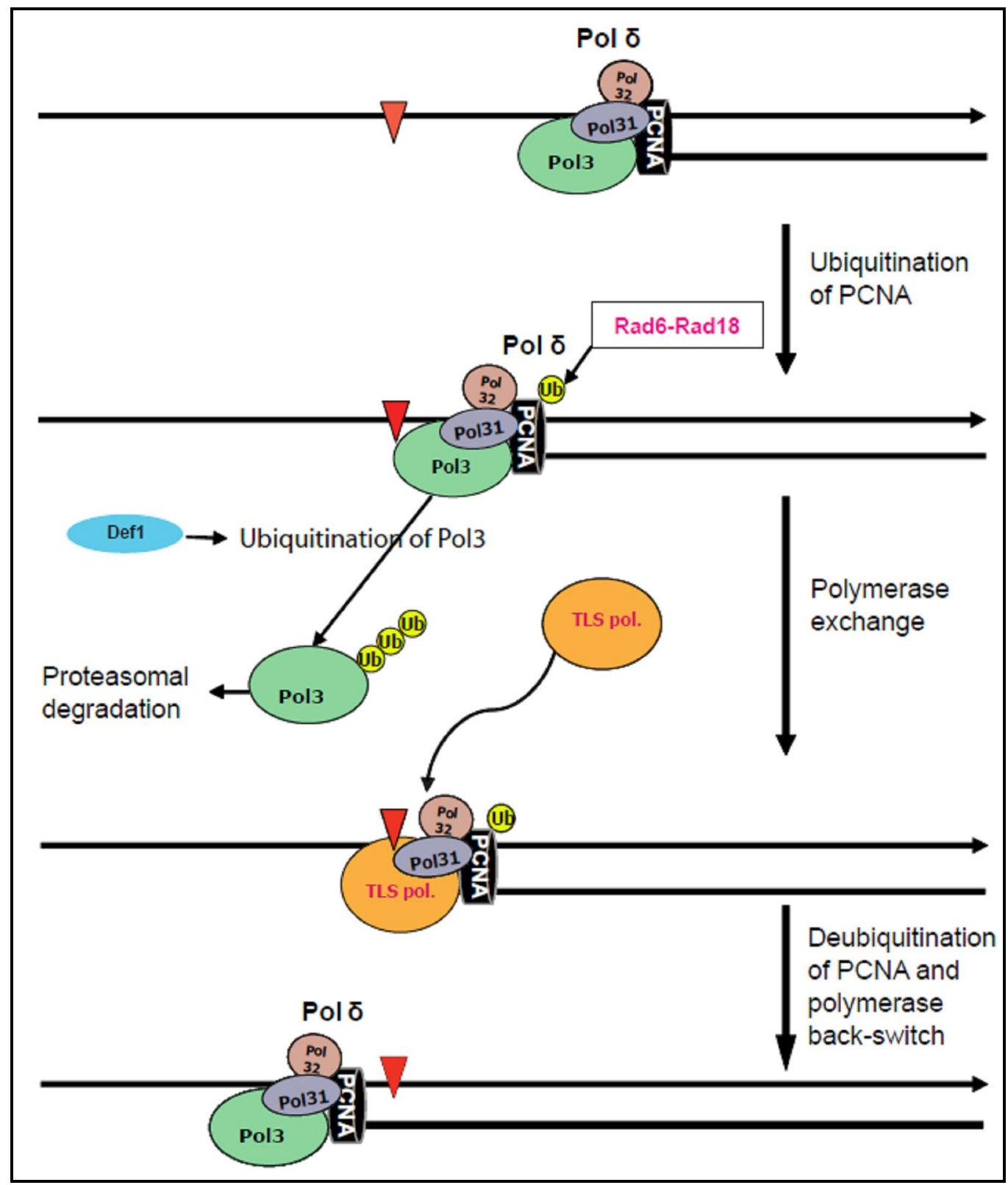

Figure 26 Model for polymerase exchange at a DNA damage site DNA damage stalls the replication complex, and triggers the ubiquitination of PCNA by $\operatorname{Rad} 6 / \operatorname{Rad} 18$ at the stalled fork. Monoubiquitinated PCNA promotes polymerase exchange, for which to occur, first Pol3 is removed from the stalled complex through ubiquitination mediated proteasomal degradation, assisted by Def1. A TLS polymerase takes over the place of Pol3, and together with Pol31 and Pol32, carries out lesion bypass. We postulate that after the deubiquitination of PCNA, Pol3 regains its place at the replication complex, and normal replication resumes. For simplicity, only half of the replication fork is shown. The DNA damage site on the template strand is marked by a red inverted triagle symbol. 
Our data raises an interesting question: how the RAD30-encoded TLS polymerase, Poln can operate independently of Def1? Our results imply that Pol3 does not have to be removed from the stalled fork for Poln-dependent UV-lesion bypass to occur. Pol $\eta$ is mainly specialized for the error-free bypass of cyclobutane pyrimidine dimers, formed upon UV irradiation [113, 218]. Since UV radiaton is one of the most common DNA damage source in most living organisms, it is reasonable to assume that Poln should have preference over the other error-prone TLS polymerases in the bypass of UV-induced DNA lesions.

Poln, a Y family polymerase, differs from the other TLS polymerases, Rev1

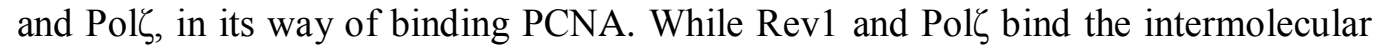
interface at the outer face of the PCNA ring [126, 127], Pol $\eta$, similarly to Pol $\delta$, binds the interdomain connector loop of PCNA through its conserved PCNA-interacting peptide motif [125]. Given, that PCNA is a homotrimer ring, Pol $\delta$ and Pol $\eta$ could bind the same PCNA ring simultaneously.

We presume that transient conformational changes, probably induced by the stalling of the fork and ubiquitination of PCNA, could allow Poln to take over synthesis from Pol $\delta$, as also suggested by in vitro experiments [139], while both remain attached to PCNA. Since Poln synthesizes opposite pyrimidine dimers with the same kinetics as it does opposite undamaged DNA [219], rapid bypass can occur. Deubiquitilation of PCNA would restore the original conformation and Pol $\delta$ could continue synthesis. A similar mechanism has already been described in bacteria [135].

We note that this is in accord with the in vivo finding that Pol32 is not needed for TT dimer bypass carried out by Poln [218]. On the other hand, when the damage poses a kinetic barrier also to the TLS polymerases, for the slower kinetic damage bypass to occur Pol3 has to be removed so that the TLS polymerases could form a stable complex with Pol31 and Pol32. This would also explain the epistasis of RAD30 with DEF1 in the bypass of MMS-induced DNA lesions, since the efficiency of incorporation by Pol $\eta$ is reduced $\sim 20$ fold opposite $\mathrm{O}^{6}$-methylguanine, and $\sim 1000$ fold opposite an abasic site [128, 220].

A recent article by Baranovskiy et al., that was published during the preparation of the manuscript, which makes the bases of this thesis, shows that the accessory subunits of human Pol $\delta$ can interact in vitro with hRev3, the catalytic subunit of human Polל, but not with the catalytic subunits of hPol $\alpha$ or hPole [221]. This result, and the high conservation between elements of DNA lesion bypass from 
yeasts to humans, including the $\operatorname{Rad} 6 / \operatorname{Rad} 18, \operatorname{Rad} 5 / \mathrm{Mms} 2 / \mathrm{Ubc} 13$ complexes and their enzymatic activities, the TLS polymerases and PCNA ubiquitination [222], strongly suggest that subunit recombination between different DNA polymerases, similar to that we propose in yeast, drives polymerase exchange in higher eukaryotes as well.

Many elements of DNA lesion bypass proved to be highly conserved from yeasts to humans, including the $\operatorname{Rad} 6 / \operatorname{Rad} 18, \operatorname{Rad} 5 / \mathrm{Mms} 2 / \mathrm{Ubc13}$ complexes and their enzymatic activities, the TLS polymerases, PCNA ubiquitination [78, 222]. The role of TLS polymerase in mutagenesis and in cancer makes it highly important to identify the human homologue of Def1, and to investigate whether a mechanism of subunit recombination between different DNA polymerases, similar to that we observed in yeast, drives polymerase exchange for mutagenesis in higher eukaryotes as well. 


\section{Acknowledgement}

It would not have been possible to write this doctoral thesis without the help and support of the kind people around me, to only some of whom it is possible to give particular mention here.

First of all I would like to express my sincere gratitude to my supervisor Dr. Unk Ildikó for offering me the opportunity to work in her group and leading my work on diverse exciting projects; for the continuous support of my Ph.D study and research, for her patience, motivation, faith, and immense knowledge. Her guidance helped me in all the time of research and writing of this thesis.

Besides my supervisor, I would like to thank Prof. Raskó István for his encouragement, insightful comments and hard questions.

I thank my fellow labmates in the DNA Repair Group: Halmai Miklós, Vamsi Krishna Gali, Minorits Szilvi and many more for the stimulating discussions, for the sleepless nights we were working together before deadlines, and for all the fun we have had in the past years.

Also I thank my friends in BRC for the memorable lunch breaks and constructive disscutions and all my friends outside BRC for their love and support.

In particular, I am grateful to Dr. Juhász Szilvia, for being my best friend and supporter and for encouraging me whenever I started to loose hope.

Last but not the least, I would like to thank the Lord God for His grace and constant guidance in my life and my family: especially my parents Irén and Herman Daraba, for loving me and supporting me spiritually throughout my life and my favourite Aunt Tanti Rozi for her constant support and love. 


\section{References}

1. Watson, J.D. and F.H. Crick, Molecular structure of nucleic acids; a structure for deoxyribose nucleic acid. Nature, 1953. 171(4356): p. 737-8.

2. Broomfield, S., T. Hryciw, and W. Xiao, DNA postreplication repair and mutagenesis in Saccharomyces cerevisiae. Mutat Res, 2001. 486(3): p. 16784.

3. Friedberg, E.C., Eukaryotic DNA repair: glimpses through the yeast Saccharomyces cerevisiae. Bioessays, 1991. 13(6): p. 295-302.

4. Kraemer, K.H., Sunlight and skin cancer: another link revealed. Proc Natl Acad Sci U S A, 1997. 94(1): p. 11-4.

5. Stein, J.J., The carcinogenic hazards of ionizing radiation in diagnostic and therapeutic radiology. CA Cancer J Clin, 1967. 17(6): p. 278-87.

6. Lindahl, T. and R.D. Wood, Quality control by DNA repair. Science, 1999. 286(5446): p. 1897-905.

7. Kikugawa, K., et al., Interaction of nitric oxide with glutathione or cysteine generates reactive oxygen species causing DNA single strand breaks. Biol Pharm Bull, 2005. 28(6): p. 998-1003.

8. Finkel, T. and N.J. Holbrook, Oxidants, oxidative stress and the biology of ageing. Nature, 2000. 408(6809): p. 239-47.

9. Hoeijmakers, J.H., Genome maintenance mechanisms for preventing cancer. Nature, 2001. 411(6835): p. 366-74.

10. Peltomaki, P., DNA mismatch repair and cancer. Mutat Res, 2001. 488(1): p. 77-85.

11. Kuzminov, A., Collapse and repair of replication forks in Escherichia coli. Mol Microbiol, 1995. 16(3): p. 373-84.

12. Zhou, B.B. and S.J. Elledge, The DNA damage response: putting checkpoints in perspective. Nature, 2000. 408(6811): p. 433-9.

13. Harper, J.W. and S.J. Elledge, The DNA damage response: ten years after. Mol Cell, 2007. 28(5): p. 739-45.

14. Huen, M.S. and J. Chen, The DNA damage response pathways: at the crossroad of protein modifications. Cell Res, 2008. 18(1): p. 8-16.

15. Sancar, A., Structure and function of DNA photolyase and cryptochrome bluelight photoreceptors. Chem Rev, 2003. 103(6): p. 2203-37.

16. Selby, C.P. and A. Sancar, A cryptochrome/photolyase class of enzymes with single-stranded DNA-specific photolyase activity. Proc Natl Acad Sci U S A, 2006. 103(47): p. 17696-700.

17. Lucas-Lledo, J.I. and M. Lynch, Evolution of mutation rates: phylogenomic analysis of the photolyase/cryptochrome family. Mol Biol Evol, 2009. 26(5): p. 1143-53.

18. Srivenugopal, K.S., et al., Ubiquitination-dependent proteolysis of O6methylguanine-DNA methyltransferase in human and murine tumor cells following inactivation with O6-benzylguanine or 1,3-bis(2-chloroethyl)-1nitrosourea. Biochemistry, 1996. 35(4): p. 1328-34.

19. Sedgwick, B., Nitrosated peptides and polyamines as endogenous mutagens in O6-alkylguanine-DNA alkyltransferase deficient cells. Carcinogenesis, 1997. 18(8): p. 1561-7.

20. Gerson, S.L., Clinical relevance of MGMT in the treatment of cancer. J Clin Oncol, 2002. 20(9): p. 2388-99. 
21. Begley, T.J. and L.D. Samson, AlkB mystery solved: oxidative demethylation of N1-methyladenine and N3-methylcytosine adducts by a direct reversal mechanism. Trends Biochem Sci, 2003. 28(1): p. 2-5.

22. Kataoka, H., Y. Yamamoto, and M. Sekiguchi, A new gene (alkB) of Escherichia coli that controls sensitivity to methyl methane sulfonate. $\mathrm{J}$ Bacteriol, 1983. 153(3): p. 1301-7.

23. Chen, B.J., P. Carroll, and L. Samson, The Escherichia coli AlkB protein protects human cells against alkylation-induced toxicity. J Bacteriol, 1994. 176(20): p. 6255-61.

24. Memisoglu, A. and L. Samson, Base excision repair in yeast and mammals. Mutat Res, 2000. 451(1-2): p. 39-51.

25. Friedberg, E.C., Out of the shadows and into the light: the emergence of DNA repair. Trends Biochem Sci, 1995. 20(10): p. 381.

26. Hess, M.T., et al., Bipartite substrate discrimination by human nucleotide excision repair. Proc Natl Acad Sci U S A, 1997. 94(13): p. 6664-9.

27. Perry, J.J., et al., Structural dynamics in DNA damage signaling and repair. Curr Opin Struct Biol, 2010. 20(3): p. 283-94.

28. Friedberg, E.C., et al., Nucleotide excision repair in the yeast Saccharomyces cerevisiae: its relationship to specialized mitotic recombination and RNA polymerase II basal transcription. Philos Trans R Soc Lond B Biol Sci, 1995. 347(1319): p. 63-8.

29. Tomkinson, A.E., et al., Yeast DNA repair and recombination proteins Rad1 and Rad10 constitute a single-stranded-DNA endonuclease. Nature, 1993. 362(6423): p. 860-2.

30. Hoeijmakers, J.H. and D. Bootsma, Molecular genetics of eukaryotic DNA excision repair. Cancer Cells, 1990. 2(10): p. 311-20.

31. Lehmann, A.R., DNA polymerases and repair synthesis in NER in human cells. DNA Repair (Amst), 2011. 10(7): p. 730-3.

32. Friedberg, E.C., Cockayne syndrome--a primary defect in DNA repair, transcription, both or neither? Bioessays, 1996. 18(9): p. 731-8.

33. Lehmann, A.R., D. McGibbon, and M. Stefanini, Xeroderma pigmentosum. Orphanet J Rare Dis, 2011. 6: p. 70.

34. Lans, H., et al., Involvement of global genome repair, transcription coupled repair, and chromatin remodeling in UV DNA damage response changes during development. PLoS Genet, 2010. 6(5): p. e1000941.

35. Mellon, I., et al., Transcription-coupled repair deficiency and mutations in human mismatch repair genes. Science, 1996. 272(5261): p. 557-60.

36. Sarasin, A. and A. Stary, New insights for understanding the transcriptioncoupled repair pathway. DNA Repair (Amst), 2007. 6(2): p. 265-9.

37. Smerdon, M.J. and F. Thoma, Site-specific DNA repair at the nucleosome level in a yeast minichromosome. Cell, 1990. 61(4): p. 675-84.

38. Marti, T.M., C. Kunz, and O. Fleck, DNA mismatch repair and mutation avoidance pathways. J Cell Physiol, 2002. 191(1): p. 28-41.

39. Iyer, R.R., et al., DNA mismatch repair: functions and mechanisms. Chem Rev, 2006. 106(2): p. 302-23.

40. Aaltonen, L.A., et al., Clues to the pathogenesis offamilial colorectal cancer. Science, 1993. 260(5109): p. 812-6.

41. Buermeyer, A.B., et al., Mammalian DNA mismatch repair. Annu Rev Genet, 1999. 33: p. 533-64. 
42. Jackson, S.P., Sensing and repairing DNA double-strand breaks.

Carcinogenesis, 2002. 23(5): p. 687-96.

43. Feng, W., et al., Replication stress-induced chromosome breakage is correlated with replication fork progression and is preceded by singlestranded DNA formation. G3 (Bethesda), 2011. 1(5): p. 327-35.

44. Takata, M., et al., Homologous recombination and non-homologous endjoining pathways of DNA double-strand break repair have overlapping roles in the maintenance of chromosomal integrity in vertebrate cells. EMBO J, 1998. 17(18): p. 5497-508.

45. Sonoda, E., et al., Homologous DNA recombination in vertebrate cells. Proc Natl Acad Sci U S A, 2001. 98(15): p. 8388-94.

46. Galkin, V.E., et al., The Rad51/RadA N-terminal domain activates nucleoprotein filament ATPase activity. Structure, 2006. 14(6): p. 983-92.

47. Chen, P.L., et al., The BRC repeats in BRCA2 are critical for RAD51 binding and resistance to methyl methanesulfonate treatment. Proc Natl Acad Sci U S A, 1998. 95(9): p. 5287-92.

48. Featherstone, C. and S.P. Jackson, $K u$, a DNA repair protein with multiple cellular functions? Mutat Res, 1999. 434(1): p. 3-15.

49. Herrmann, G., T. Lindahl, and P. Schar, Saccharomyces cerevisiae LIF1: a function involved in DNA double-strand break repair related to mammalian XRCC4. EMBO J, 1998. 17(14): p. 4188-98.

50. $\quad \mathrm{Li}, \mathrm{Z}$., et al., The XRCC4 gene encodes a novel protein involved in DNA double-strand break repair and $V(D) J$ recombination. Cell, 1995. 83(7): p. 1079-89.

51. Haber, J.E., The many interfaces of Mre11. Cell, 1998. 95(5): p. 583-6.

52. Petrini, J.H., The Mrell complex and ATM: collaborating to navigate S phase. Curr Opin Cell Biol, 2000. 12(3): p. 293-6.

53. Lieber, M.R., The biochemistry and biological significance of nonhomologous DNA end joining: an essential repair process in multicellular eukaryotes. Genes Cells, 1999. 4(2): p. 77-85.

54. Boiteux, S. and S. Jinks-Robertson, DNA repair mechanisms and the bypass of DNA damage in Saccharomyces cerevisiae. Genetics, 2013. 193(4): p. 102564.

55. Rupp, W.D., et al., Exchanges between DNA strands in ultraviolet-irradiated Escherichia coli. J Mol Biol, 1971. 61(1): p. 25-44.

56. Lehmann, A.R., Postreplication repair of DNA in ultraviolet-irradiated mammalian cells. J Mol Biol, 1972. 66(3): p. 319-37.

57. Prakash, L., Characterization of postreplication repair in Saccharomyces cerevisiae and effects of rad6, rad18, rev3 and rad52 mutations. Mol Gen Genet, 1981. 184(3): p. 471-8.

58. di Caprio, L. and B.S. Cox, DNA synthesis in UV-irradiated yeast. Mutat Res, 1981. 82(1): p. 69-85.

59. Ganesan, A.K., Persistence of pyrimidine dimers during post-replication repair in ultraviolet light-irradiated Escherichia coli K12. J Mol Biol, 1974. 87(1): p. 103-19.

60. Sarasin, A.R. and P.C. Hanawalt, Replication of ultraviolet-irradiated simian virus 40 in monkey kidney cells. J Mol Biol, 1980. 138(2): p. 299-319.

61. Gangavarapu, V., S. Prakash, and L. Prakash, Requirement of RAD52 group genes for postreplication repair of UV-damaged DNA in Saccharomyces cerevisiae. Mol Cell Biol, 2007. 27(21): p. 7758-64. 
62. Krogh, B.O. and L.S. Symington, Recombination proteins in yeast. Annu Rev Genet, 2004. 38: p. 233-71.

63. Sung, P. and H. Klein, Mechanism of homologous recombination: mediators and helicases take on regulatory functions. Nat Rev Mol Cell Biol, 2006.

7(10): p. 739-50.

64. Krejci, L., et al., DNA helicase Srs2 disrupts the Rad51 presynaptic filament. Nature, 2003. 423(6937): p. 305-9.

65. Schiestl, R.H., S. Prakash, and L. Prakash, The SRS2 suppressor of rad6 mutations of Saccharomyces cerevisiae acts by channeling DNA lesions into the RAD52 DNA repair pathway. Genetics, 1990. 124(4): p. 817-31.

66. Veaute, X., et al., The Srs 2 helicase prevents recombination by disrupting Rad51 nucleoprotein filaments. Nature, 2003. 423(6937): p. 309-12.

67. Haracska, L., et al., Opposing effects of ubiquitin conjugation and SUMO modification of PCNA on replicational bypass of DNA lesions in Saccharomyces cerevisiae. Mol Cell Biol, 2004. 24(10): p. 4267-74.

68. Papouli, E., et al., Crosstalk between SUMO and ubiquitin on PCNA is mediated by recruitment of the helicase Srs2p. Mol Cell, 2005. 19(1): p. 12333.

69. Pfander, B., et al., SUMO-modified PCNA recruits Srs 2 to prevent recombination during S phase. Nature, 2005. 436(7049): p. 428-33.

70. Cox, B.S. and J.M. Parry, The isolation, genetics and survival characteristics of ultraviolet light-sensitive mutants in yeast. Mutat Res, 1968. 6(1): p. 37-55.

71. Lawrence, C.W., et al., Specificity and frequency of ultraviolet-induced reversion of an iso-1-cytochrome c ochre mutant in radiation-sensitive strains of yeast. J Mol Biol, 1974. 85(1): p. 137-62.

72. Lawrence, C.W. and R. Christensen, $U V$ mutagenesis in radiation-sensitive strains of yeast. Genetics, 1976. 82(2): p. 207-32.

73. Prakash, L., Lack of chemically induced mutation in repair-deficient mutants of yeast. Genetics, 1974. 78(4): p. 1101-18.

74. Cassier-Chauvat, C. and F. Fabre, A similar defect in UV-induced mutagenesis conferred by the rad6 and rad18 mutations of Saccharomyces cerevisiae. Mutat Res, 1991. 254(3): p. 247-53.

75. Armstrong, J.D., D.N. Chadee, and B.A. Kunz, Roles for the yeast RAD18 and RAD52 DNA repair genes in UV mutagenesis. Mutat Res, 1994. 315(3): p. 281-93.

76. Bailly, V., et al., Specific complex formation between yeast RAD6 and RAD18 proteins: a potential mechanism for targeting RAD6 ubiquitin-conjugating activity to DNA damage sites. Genes Dev, 1994. 8(7): p. 811-20.

77. Bailly, V., et al., Yeast DNA repair proteins Rad6 and Rad18 form a heterodimer that has ubiquitin conjugating, DNA binding, and ATP hydrolytic activities. J Biol Chem, 1997. 272(37): p. 23360-5.

78. Prakash, S., R.E. Johnson, and L. Prakash, Eukaryotic translesion synthesis DNA polymerases: specificity of structure and function. Annu Rev Biochem, 2005. 74: p. 317-53.

79. Torres-Ramos, C.A., S. Prakash, and L. Prakash, Requirement of RAD5 and $M M S 2$ for postreplication repair of UV-damaged DNA in Saccharomyces cerevisiae. Mol Cell Biol, 2002. 22(7): p. 2419-26.

80. Hoege, C., et al., RAD6-dependent DNA repair is linked to modification of PCNA by ubiquitin and SUMO. Nature, 2002. 419(6903): p. 135-41. 
81. Stelter, P. and H.D. Ulrich, Control of spontaneous and damage-induced mutagenesis by SUMO and ubiquitin conjugation. Nature, 2003. 425(6954): p. 188-91.

82. Haracska, L., et al., Ubiquitylation of yeast proliferating cell nuclear antigen and its implications for translesion DNA synthesis. Proc Natl Acad Sci U S A, 2006. 103(17): p. 6477-82.

83. Wood, A., P. Garg, and P.M. Burgers, A ubiquitin-binding motif in the translesion DNA polymerase Rev1 mediates its essential functional interaction with ubiquitinated proliferating cell nuclear antigen in response to DNA damage. J Biol Chem, 2007. 282(28): p. 20256-63.

84. Huttner, D. and H.D. Ulrich, Cooperation of replication protein A with the ubiquitin ligase Rad18 in DNA damage bypass. Cell Cycle, 2008. 7(23): p. 3629-33.

85. Gangavarapu, V., et al., Mms2-Ubc13-dependent and-independent roles of Rad5 ubiquitin ligase in postreplication repair and translesion DNA synthesis in Saccharomyces cerevisiae. Mol Cell Biol, 2006. 26(20): p. 7783-90.

86. Kiakos, K., et al., Saccharomyces cerevisiae RAD5 influences the excision repair of DNA minor groove adducts. J Biol Chem, 2002. 277(46): p. 4457681.

87. Johnson, R.E., et al., Saccharomyces cerevisiae RAD5-encoded DNA repair protein contains DNA helicase and zinc-binding sequence motifs and affects the stability of simple repetitive sequences in the genome. Mol Cell Biol, 1992. 12(9): p. 3807-18.

88. Johnson, R.E., S. Prakash, and L. Prakash, Yeast DNA repair protein RAD5 that promotes instability of simple repetitive sequences is a DNA-dependent ATPase. J Biol Chem, 1994. 269(45): p. 28259-62.

89. Carlile, C.M., et al., Synthesis of free and proliferating cell nuclear antigenbound polyubiquitin chains by the RING E3 ubiquitin ligase Rad5. J Biol Chem, 2009. 284(43): p. 29326-34.

90. Parker, J.L. and H.D. Ulrich, Mechanistic analysis of PCNA polyubiquitylation by the ubiquitin protein ligases Rad18 and Rad5. EMBO J, 2009. 28(23): p. 3657-66.

91. Blastyak, A., et al., Yeast Rad5 protein required for postreplication repair has a DNA helicase activity specific for replication fork regression. Mol Cell, 2007. 28(1): p. 167-75.

92. Motegi, A., et al., Polyubiquitination of proliferating cell nuclear antigen by HLTF and SHPRH prevents genomic instability from stalled replication forks. Proc Natl Acad Sci U S A, 2008. 105(34): p. 12411-6.

93. Motegi, A., et al., Human SHPRH suppresses genomic instability through proliferating cell nuclear antigen polyubiquitination. J Cell Biol, 2006. 175(5): p. 703-8.

94. Unk, I., et al., Human HLTF functions as a ubiquitin ligase for proliferating cell nuclear antigen polyubiquitination. Proc Natl Acad Sci U S A, 2008. 105(10): p. 3768-73.

95. Unk, I., et al., Human SHPRH is a ubiquitin ligase for Mms2-Ubc13dependent polyubiquitylation of proliferating cell nuclear antigen. Proc Natl Acad Sci U S A, 2006. 103(48): p. 18107-12.

96. Chen, I.P., et al., A homolog of ScRAD5 is involved in DNA repair and homologous recombination in Arabidopsis. Plant Physiol, 2008. 146(4): p. 1786-96. 
97. Doe, C.L., et al., Cloning and characterisation of the Schizosaccharomyces pombe rad8 gene, a member of the SNF2 helicase family. Nucleic Acids Res, 1993. 21(25): p. 5964-71.

98. Gong, X., et al., Developmental regulation of Zbu1, a DNA-binding member of the SWI2/SNF2 family. Dev Biol, 1997. 183(2): p. 166-82.

99. Malik, M. and J.L. Nitiss, DNA repair functions that control sensitivity to topoisomerase-targeting drugs. Eukaryot Cell, 2004. 3(1): p. 82-90.

100. Zhang, Q., D. Ekhterae, and K.H. Kim, Molecular cloning and characterization of P113, a mouse SNF2/SWI2-related transcription factor. Gene, 1997. 202(1-2): p. 31-7.

101. Eki, T., et al., A genome-wide survey and systematic RNAi-based characterization of helicase-like genes in Caenorhabditis elegans. DNA Res, 2007. 14(4): p. 183-99.

102. Pothof, J., et al., Identification of genes that protect the C. elegans genome against mutations by genome-wide RNAi. Genes Dev, 2003. 17(4): p. 443-8.

103. Hanawalt, P.C., Controlling the efficiency of excision repair. Mutat Res, 2001. 485(1): p. 3-13.

104. Waters, L.S., et al., Eukaryotic translesion polymerases and their roles and regulation in DNA damage tolerance. Microbiol Mol Biol Rev, 2009. 73(1): p. 134-54.

105. Yang, W. and R. Woodgate, What a difference a decade makes: insights into translesion DNA synthesis. Proc Natl Acad Sci U S A, 2007. 104(40): p. 15591-8.

106. Wang, Z., Translesion synthesis by the UmuC family of DNA polymerases. Mutat Res, 2001. 486(2): p. 59-70.

107. Johnson, R.E., et al., Eukaryotic polymerases iota and zeta act sequentially to bypass DNA lesions. Nature, 2000. 406(6799): p. 1015-9.

108. Lemontt, J.F., Mutants of yeast defective in mutation induced by ultraviolet light. Genetics, 1971. 68(1): p. 21-33.

109. Lawrence, C.W., P.E. Nisson, and R.B. Christensen, UV and chemical mutagenesis in rev7 mutants of yeast. Mol Gen Genet, 1985. 200(1): p. 86-91.

110. Andersen, P.L., F. Xu, and W. Xiao, Eukaryotic DNA damage tolerance and translesion synthesis through covalent modifications of PCNA. Cell Res, 2008. 18(1): p. 162-73.

111. Hubscher, U., G. Maga, and S. Spadari, Eukaryotic DNA polymerases. Annu Rev Biochem, 2002. 71: p. 133-63.

112. Morrison, A., et al., REV3, a Saccharomyces cerevisiae gene whose function is required for induced mutagenesis, is predicted to encode a nonessential DNA polymerase. J Bacteriol, 1989. 171(10): p. 5659-67.

113. Nelson, J.R., C.W. Lawrence, and D.C. Hinkle, Thymine-thymine dimer bypass by yeast DNA polymerase zeta. Science, 1996. 272(5268): p. 1646-9.

114. Johnson, R.E., et al., Yeast DNA polymerase zeta (zeta) is essential for errorfree replication past thymine glycol. Genes Dev, 2003. 17(1): p. 77-87.

115. Lawrence, C.W. and R.B. Christensen, Ultraviolet-induced reversion of cycl alleles in radiation-sensitive strains of yeast. III. rev3 mutant strains. Genetics, 1979. 92(2): p. 397-408.

116. Lawrence, C.W., T. O'Brien, and J. Bond, UV-induced reversion of his 4 frameshift mutations in rad6, rev1, and rev3 mutants of yeast. Mol Gen Genet, 1984. 195(3): p. 487-90. 
117. Johnson, R.E., et al., Identification of APN2, the Saccharomyces cerevisiae homolog of the major human AP endonuclease HAP1, and its role in the repair of abasic sites. Genes Dev, 1998. 12(19): p. 3137-43.

118. Prakash, L., Effect of Genes Controlling Radiation Sensitivity on Chemically Induced Mutations in SACCHAROMYCES CEREVISIAE. Genetics, 1976. 83(2): p. 285-301.

119. Sanders, L.H., et al., Role of Pseudomonas aeruginosa dinB-encoded DNA polymerase IV in mutagenesis. J Bacteriol, 2006. 188(24): p. 8573-85.

120. Wagner, J., et al., The dinB gene encodes a novel E. coli DNA polymerase, DNA pol IV, involved in mutagenesis. Mol Cell, 1999. 4(2): p. 281-6.

121. McDonald, J.P., A.S. Levine, and R. Woodgate, The Saccharomyces cerevisiae RAD30 gene, a homologue of Escherichia coli dinB and umuC, is DNA damage inducible and functions in a novel error-free postreplication repair mechanism. Genetics, 1997. 147(4): p. 1557-68.

122. Roush, A.A., et al., Deletion of the Saccharomyces cerevisiae gene RAD30 encoding an Escherichia coli DinB homolog confers UV radiation sensitivity and altered mutability. Mol Gen Genet, 1998. 257(6): p. 686-92.

123. Johnson, R.E., S. Prakash, and L. Prakash, Efficient bypass of a thyminethymine dimer by yeast DNA polymerase, Poleta. Science, 1999. 283(5404): p. 1001-4.

124. Johnson, R.E., S. Prakash, and L. Prakash, Requirement of DNA polymerase activity of yeast Rad30 protein for its biological function. J Biol Chem, 1999. 274(23): p. 15975-7.

125. Haracska, L., et al., Interaction with PCNA is essential for yeast DNA polymerase eta function. Mol Cell, 2001. 8(2): p. 407-15.

126. Northam, M.R., et al., A novel function of DNA polymerase zeta regulated by PCNA. EMBO J, 2006. 25(18): p. 4316-25.

127. Sharma, N.M., O.V. Kochenova, and P.V. Shcherbakova, The non-canonical protein binding site at the monomer-monomer interface of yeast proliferating cell nuclear antigen (PCNA) regulates the Rev1-PCNA interaction and Polzeta/Rev1-dependent translesion DNA synthesis. J Biol Chem, 2011. 286(38): p. 33557-66.

128. Haracska, L., S. Prakash, and L. Prakash, Replication past O(6)methylguanine by yeast and human DNA polymerase eta. Mol Cell Biol, 2000. 20(21): p. 8001-7.

129. Garg, P. and P.M. Burgers, DNA polymerases that propagate the eukaryotic DNA replication fork. Crit Rev Biochem Mol Biol, 2005. 40(2): p. 115-28.

130. Cox, M.M., The nonmutagenic repair of broken replication forks via recombination. Mutat Res, 2002. 510(1-2): p. 107-20.

131. Friedberg, E.C., A.R. Lehmann, and R.P. Fuchs, Trading places: how do DNA polymerases switch during translesion DNA synthesis? Mol Cell, 2005. 18(5): p. 499-505.

132. Yang, J., et al., The dynamic processivity of the T4 DNA polymerase during replication. Proc Natl Acad Sci U S A, 2004. 101(22): p. 8289-94.

133. Johnson, D.E., et al., Exchange of DNA polymerases at the replication fork of bacteriophage T7. Proc Natl Acad Sci U S A, 2007. 104(13): p. 5312-7.

134. Hamdan, S.M., et al., Dynamic DNA helicase-DNA polymerase interactions assure processive replication fork movement. Mol Cell, 2007. 27(4): p. 53949. 
135. Indiani, C., et al., A sliding-clamp toolbelt binds high-and low-fidelity DNA polymerases simultaneously. Mol Cell, 2005. 19(6): p. 805-15.

136. Furukohri, A., M.F. Goodman, and H. Maki, A dynamic polymerase exchange with Escherichia coli DNA polymerase IV replacing DNA polymerase III on the sliding clamp. J Biol Chem, 2008. 283(17): p. 11260-9.

137. Bienko, M., et al., Ubiquitin-binding domains in Y-family polymerases regulate translesion synthesis. Science, 2005. 310(5755): p. 1821-4.

138. Watanabe, K., et al., Rad18 guides poleta to replication stalling sites through physical interaction and PCNA monoubiquitination. EMBO J, 2004. 23(19): p. 3886-96.

139. Zhuang, Z., et al., Regulation of polymerase exchange between Poleta and Poldelta by monoubiquitination of PCNA and the movement of DNA polymerase holoenzyme. Proc Natl Acad Sci U S A, 2008. 105(14): p. 5361-6.

140. Hershko, A., et al., Proposed role of ATP in protein breakdown: conjugation of protein with multiple chains of the polypeptide of ATP-dependent proteolysis. Proc Natl Acad Sci U S A, 1980. 77(4): p. 1783-6.

141. Hershko, A. and A. Ciechanover, The ubiquitin pathway for the degradation of intracellular proteins. Prog Nucleic Acid Res Mol Biol, 1986. 33: p. 19-56, 301.

142. Wang, C., et al., Solution structure of ThiS and implications for the evolutionary roots of ubiquitin. Nat Struct Biol, 2001. 8(1): p. 47-51.

143. Lake, M.W., et al., Mechanism of ubiquitin activation revealed by the structure of a bacterial MoeB-MoaD complex. Nature, 2001. 414(6861): $\mathrm{p}$. 325-9.

144. Pickart, C.M., Mechanisms underlying ubiquitination. Annu Rev Biochem, 2001. 70: p. 503-33.

145. Bloom, J., et al., Proteasome-mediated degradation of p21 via $\mathrm{N}$-terminal ubiquitinylation. Cell, 2003. 115(1): p. 71-82.

146. Witte, O.N., et al., Retraction. Science, 2005. 307(5707): p. 206.

147. Dikic, I. and M. Robertson, Ubiquitin ligases and beyond. BMC Biol, 2012. 10: p. 22.

148. Komander, D., The emerging complexity of protein ubiquitination. Biochem Soc Trans, 2009. 37(Pt 5): p. 937-53.

149. Ikeda, F. and I. Dikic, Atypical ubiquitin chains: new molecular signals. 'Protein Modifications: Beyond the Usual Suspects' review series. EMBO Rep, 2008. 9(6): p. 536-42.

150. Hicke, L., Protein regulation by monoubiquitin. Nat Rev Mol Cell Biol, 2001. 2(3): p. 195-201.

151. Lecker, S.H., A.L. Goldberg, and W.E. Mitch, Protein degradation by the ubiquitin-proteasome pathway in normal and disease states. J Am Soc Nephrol, 2006. 17(7): p. 1807-19.

152. Winkler, L.L., J. Hwang, and R.F. Kalejta, Ubiquitin-independent proteasomal degradation of tumor suppressors by human cytomegalovirus pp71 requires the $19 S$ regulatory particle. J Virol, 2013. 87(8): p. 4665-71.

153. Glickman, M.H. and A. Ciechanover, The ubiquitin-proteasome proteolytic pathway: destruction for the sake of construction. Physiol Rev, 2002. 82(2): p. 373-428.

154. Miranda, M. and A. Sorkin, Regulation of receptors and transporters by ubiquitination: new insights into surprisingly similar mechanisms. Mol Interv, 2007. 7(3): p. 157-67. 
155. Nathan, J.A., et al., Why do cellular proteins linked to K63-polyubiquitin chains not associate with proteasomes? EMBO J, 2013. 32(4): p. 552-65.

156. Schulman, B.A. and J.W. Harper, Ubiquitin-like protein activation by E1 enzymes: the apex for downstream signalling pathways. Nat Rev Mol Cell Biol, 2009. 10(5): p. 319-31.

157. Groettrup, M., et al., Activating the ubiquitin family: UBA6 challenges the field. Trends Biochem Sci, 2008. 33(5): p. 230-7.

158. van Wijk, S.J. and H.T. Timmers, The family of ubiquitin-conjugating enzymes (E2s): deciding between life and death of proteins. FASEB J, 2010. 24(4): p. 981-93.

159. Metzger, M.B., V.A. Hristova, and A.M. Weissman, HECT and RING finger families of E3 ubiquitin ligases at a glance. J Cell Sci, 2012. 125(Pt 3): p. 5317.

160. Skaar, J.R. and M. Pagano, Control of cell growth by the SCF and APC/C ubiquitin ligases. Curr Opin Cell Biol, 2009. 21(6): p. 816-24.

161. Pickart, C.M. and M.J. Eddins, Ubiquitin: structures, functions, mechanisms. Biochim Biophys Acta, 2004. 1695(1-3): p. 55-72.

162. Woudstra, E.C., et al., A Rad26-Defl complex coordinates repair and RNA pol II proteolysis in response to DNA damage. Nature, 2002. 415(6874): p. 92933.

163. van Gool, A.J., et al., RAD26, the functional S. cerevisiae homolog of the Cockayne syndrome B gene ERCC6. EMBO J, 1994. 13(22): p. 5361-9.

164. de Boer, J. and J.H. Hoeijmakers, Nucleotide excision repair and human syndromes. Carcinogenesis, 2000. 21(3): p. 453-60.

165. van den Boom, V., N.G. Jaspers, and W. Vermeulen, When machines get stuck--obstructed RNA polymerase II: displacement, degradation or suicide. Bioessays, 2002. 24(9): p. 780-4.

166. Perutz, M.F., Glutamine repeats and neurodegenerative diseases: molecular aspects. Trends Biochem Sci, 1999. 24(2): p. 58-63.

167. Perutz, M.F., Glutamine repeats and neurodegenerative diseases. Brain Res Bull, 1999. 50(5-6): p. 467.

168. Zoghbi, H.Y. and H.T. Orr, Glutamine repeats and neurodegeneration. Annu Rev Neurosci, 2000. 23: p. 217-47.

169. Chen, Y.B., et al., Deflp is involved in telomere maintenance in budding yeast. J Biol Chem, 2005. 280(26): p. 24784-91.

170. Svejstrup, J.Q., Rescue of arrested RNA polymerase II complexes. J Cell Sci, 2003. 116(Pt 3): p. 447-51.

171. Somesh, B.P., et al., Multiple mechanisms confining RNA polymerase II ubiquitylation to polymerases undergoing transcriptional arrest. Cell, 2005. 121(6): p. 913-23.

172. Suzuki, T., et al., Identification and characterization of genes involved in glutathione production in yeast. J Biosci Bioeng, 2011. 112(2): p. 107-13.

173. Ivessa, A.S., et al., The Saccharomyces cerevisiae helicase Rrm3p facilitates replication past nonhistone protein-DNA complexes. Mol Cell, 2003. 12(6): p. 1525-36.

174. Blackburn, E.H., Switching and signaling at the telomere. Cell, 2001. 106(6): p. 661-73.

175. Cervantes, R.B. and V. Lundblad, Mechanisms of chromosome-end protection. Curr Opin Cell Biol, 2002. 14(3): p. 351-6. 
176. Lendvay, T.S., et al., Senescence mutants of Saccharomyces cerevisiae with a defect in telomere replication identify three additional EST genes. Genetics, 1996. 144(4): p. 1399-412.

177. Singer, M.S. and D.E. Gottschling, TLC1: template RNA component of Saccharomyces cerevisiae telomerase. Science, 1994. 266(5184): p. 404-9.

178. Lundblad, V. and J.W. Szostak, A mutant with a defect in telomere elongation leads to senescence in yeast. Cell, 1989. 57(4): p. 633-43.

179. Cech, T.R., T.M. Nakamura, and J. Lingner, Telomerase is a true reverse transcriptase. A review. Biochemistry (Mosc), 1997. 62(11): p. 1202-5.

180. Lingner, J., et al., Three Ever Shorter Telomere (EST) genes are dispensable for in vitro yeast telomerase activity. Proc Natl Acad Sci U S A, 1997. 94(21): p. 11190-5.

181. Lingner, J., et al., Reverse transcriptase motifs in the catalytic subunit of telomerase. Science, 1997. 276(5312): p. 561-7.

182. Chen, Q., A. Ijpma, and C.W. Greider, Two survivor pathways that allow growth in the absence of telomerase are generated by distinct telomere recombination events. Mol Cell Biol, 2001. 21(5): p. 1819-27.

183. Lundblad, V. and E.H. Blackburn, An alternative pathway for yeast telomere maintenance rescues est 1 - senescence. Cell, 1993. 73(2): p. 347-60.

184. Pompella, A., et al., The changing faces of glutathione, a cellular protagonist. Biochem Pharmacol, 2003. 66(8): p. 1499-503.

185. Yoshida, S., et al., A novel mechanism regulates $H(2) S$ and $S O(2)$ production in Saccharomyces cerevisiae. Yeast, 2011. 28(2): p. 109-21.

186. Han, Y.H. and W.H. Park, The effects of N-acetyl cysteine, buthionine sulfoximine, diethyldithiocarbamate or 3-amino-1,2,4-triazole on antimycin Atreated Calu-6 lung cells in relation to cell growth, reactive oxygen species and glutathione. Oncol Rep, 2009. 22(2): p. 385-91.

187. Chow, H.H., et al., Modulation of human glutathione s-transferases by polyphenon e intervention. Cancer Epidemiol Biomarkers Prev, 2007. 16(8): p. 1662-6.

188. Balendiran, G.K., R. Dabur, and D. Fraser, The role of glutathione in cancer. Cell Biochem Funct, 2004. 22(6): p. 343-52.

189. Yamaizumi, M. and T. Sugano, U.v.-induced nuclear accumulation of 553 is evoked through DNA damage of actively transcribed genes independent of the cell cycle. Oncogene, 1994. 9(10): p. 2775-84.

190. Ljungman, M. and F. Zhang, Blockage of RNA polymerase as a possible trigger for u.v. light-induced apoptosis. Oncogene, 1996. 13(4): p. 823-31.

191. Rothstein, R., Targeting, disruption, replacement, and allele rescue: integrative DNA transformation in yeast. Methods Enzymol, 1991. 194: p. 281-301.

192. Jones, E.W., Tackling the protease problem in Saccharomyces cerevisiae. Methods Enzymol, 1991. 194: p. 428-53.

193. Isono, E., et al., Rpn7 Is required for the structural integrity of the $26 \mathrm{~S}$ proteasome of Saccharomyces cerevisiae. J Biol Chem, 2004. 279(26): p. 27168-76.

194. Chen, P., et al., Multiple ubiquitin-conjugating enzymes participate in the in vivo degradation of the yeast MAT alpha 2 repressor. Cell, 1993. 74(2): $\mathrm{p}$. 357-69. 
195. Turner, D.L. and H. Weintraub, Expression of achaete-scute homolog 3 in Xenopus embryos converts ectodermal cells to a neural fate. Genes Dev, 1994. 8(12): p. 1434-47.

196. Mumberg, D., R. Muller, and M. Funk, Yeast vectors for the controlled expression of heterologous proteins in different genetic backgrounds. Gene, 1995. 156(1): p. 119-22.

197. Geng, F. and W.P. Tansey, Polyubiquitylation of histone H2B. Mol Biol Cell, 2008. 19(9): p. 3616-24.

198. Alani, E., L. Cao, and N. Kleckner, A method for gene disruption that allows repeated use of URA3 selection in the construction of multiply disrupted yeast strains. Genetics, 1987. 116(4): p. 541-5.

199. Brizzard, B., Epitope tagging. Biotechniques, 2008. 44(5): p. 693-5.

200. De Antoni, A. and D. Gallwitz, A novel multi-purpose cassette for repeated integrative epitope tagging of genes in Saccharomyces cerevisiae. Gene, 2000. 246(1-2): p. 179-85.

201. Knop, M., et al., Epitope tagging of yeast genes using a PCR-based strategy: more tags and improved practical routines. Yeast, 1999. 15(10B): p. 963-72.

202. Wilson, I.A., et al., The structure of an antigenic determinant in a protein. Cell, 1984. 37(3): p. 767-78.

203. Laemmli, U.K., Cleavage of structural proteins during the assembly of the head of bacteriophage T4. Nature, 1970. 227(5259): p. 680-5.

204. Ostergaard, S., L. Olsson, and J. Nielsen, Metabolic engineering of Saccharomyces cerevisiae. Microbiol Mol Biol Rev, 2000. 64(1): p. 34-50.

205. Hughes, T.R., Universal epistasis analysis. Nat Genet, 2005. 37(5): p. 457-8.

206. Roth, F.P., H.D. Lipshitz, and B.J. Andrews, Q\&A: epistasis. J Biol, 2009. 8(4): p. 35.

207. Sinha, R.P. and D.P. Hader, $U V$-induced DNA damage and repair: a review. Photochem Photobiol Sci, 2002. 1(4): p. 225-36.

208. Lawrence, C.W. and V.M. Maher, Mutagenesis in eukaryotes dependent on DNA polymerase zeta and Rev1p. Philos Trans R Soc Lond B Biol Sci, 2001. 356(1405): p. 41-6.

209. Gerik, K.J., et al., Characterization of the two small subunits of Saccharomyces cerevisiae DNA polymerase delta. J Biol Chem, 1998. 273(31): p. 19747-55.

210. Johansson, E., J. Majka, and P.M. Burgers, Structure of DNA polymerase delta from Saccharomyces cerevisiae. J Biol Chem, 2001. 276(47): p. 43824-8.

211. Acharya, N., et al., Complex formation of yeast Rev1 with DNA polymerase eta. Mol Cell Biol, 2007. 27(23): p. 8401-8.

212. Acharya, N., et al., Complex formation with Revl enhances the proficiency of Saccharomyces cerevisiae DNA polymerase zeta for mismatch extension and for extension opposite from DNA lesions. Mol Cell Biol, 2006. 26(24): p. 9555-63.

213. Guo, C., et al., Mouse Rev1 protein interacts with multiple DNA polymerases involved in translesion DNA synthesis. EMBO J, 2003. 22(24): p. 6621-30.

214. Ohashi, E., et al., Interaction of hREV1 with three human Y-family DNA polymerases. Genes Cells, 2004. 9(6): p. 523-31.

215. Unk, I., et al., Role of yeast Rad5 and its human orthologs, HLTF and SHPRH in DNA damage tolerance. DNA Repair (Amst), 2010. 9(3): p. 257-67.

216. Giot, L., et al., Involvement of the yeast DNA polymerase delta in DNA repair in vivo. Genetics, 1997. 146(4): p. 1239-51. 
217. Johansson, E., P. Garg, and P.M. Burgers, The Pol32 subunit of DNA polymerase delta contains separable domains for processive replication and proliferating cell nuclear antigen (PCNA) binding. J Biol Chem, 2004. 279(3): p. $1907-15$.

218. Gibbs, P.E., et al., The relative roles in vivo of Saccharomyces cerevisiae Pol eta, Pol zeta, Rev1 protein and Pol32 in the bypass and mutation induction of an abasic site, T-T (6-4) photoadduct and T-T cis-syn cyclobutane dimer. Genetics, 2005. 169(2): p. 575-82.

219. Washington, M.T., et al., Accuracy of thymine-thymine dimer bypass by Saccharomyces cerevisiae DNA polymerase eta. Proc Natl Acad Sci U S A, 2000. 97(7): p. 3094-9.

220. Haracska, L., et al., Inefficient bypass of an abasic site by DNA polymerase eta. J Biol Chem, 2001. 276(9): p. 6861-6.

221. Baranovskiy, A.G., et al., DNA polymerase delta and zeta switch by sharing accessory subunits of DNA polymerase delta. J Biol Chem, 2012. 287(21): p. 17281-7.

222. Chang, D.J. and K.A. Cimprich, DNA damage tolerance: when it's OK to make mistakes. Nat Chem Biol, 2009. 5(2): p. 82-90. 


\section{Summary in English}

The stalling of the replication machinery that occurs as a consequence of encountering unrepaired DNA damages is a challenging problem for cells. Stalled replication forks can undergo DNA breakage and recombination that can lead to chromosomal rearrangements and cell death. To ensure survival, cells have evolved different mechanism that can sustain DNA replication on damaged templates. These, so called DNA damage tolerance, or DNA damage bypass processes allow replication to continue on damaged DNA without actually removing the damage. DNA damage tolerance is achieved through two main mechanisms: template switching and translesion synthesis (TLS). Template switching is inherently error-free, since replication continues by using the undamaged nascent sister chromatid as template for the bypass of the lesion, while during TLS specialized polymerases take over the nascent primer end from the replicative polymerase and carry out synthesis opposite the DNA lesion in an error-free or error-prone way.

Rad6 and Rad18 are key mediators of DNA damage tolerance in the yeast Saccharomyces cerevisiae. They govern at least three different pathways for the replication of UV light-damaged DNA: 1. Rad5-dependent error-free DNA damage bypass; 2. Rad30-dependent error-free translesion synthesis; 3. Rev3-dependent errorprone translesion synthesis. Upon UV-treatment, the Rad6-Rad18 ubiquitinconjugase-ligase complex mono-ubiquitinates proliferating cell nuclear antigen (PCNA) at lysine-164. Monoubiquitinated PCNA activates the Rev3, and the Rad30dependent sub-pathways involving TLS polymerases, while further polyubiquitination of PCNA on the same residue by the Rad5-Mms2-Ubc13 ubiquitin-conjugase-ligase complex activates the Rad5 subpathway.

In this study we identify $D E F 1$ as a member of the REV3 branch of the RAD6$R A D 18$-dependent DNA damage tolerance pathway and a prerequisite for induced mutagenesis in yeast.

The TLS polymerases of the REV3 branch have to take over synthesis from the replicative polymerase stalled at a DNA lesion site, a central but poorly understood step in DNA lesion bypass. Since Def1, unlike other members of the REV3 branch, is not a DNA polymerase, we surmised that it might facilitate the exchange between the TLS and the replicative polymerases. 
Here we have appointed Def1 as a key factor for polymerase exchange. We have also established that Pol3, the catalytic subunit of the replicative DNA polymerase Pol $\delta$, was degraded upon UV-irradiation. We presented evidence that degradation of Pol3 was the result of polyubiquitination mediated proteosomal degradation, and it was dependent on DEF1 under the higher control of RAD6. Conversely, Pol31 and Pol32, the other two subunits of Pol $\delta$ were not degraded. We also demonstrated that Pol31 and Pol32 together could form a stable complex with TLS polymerase Rev1.

Our data imply that translesion synthesis polymerases carry out DNA lesion bypass in complex with Pol31 and Pol32, only after the Def1- assisted removal of Pol3 from the stalled replication fork.

Based on these results we propose a new model for polymerase exchange at stalled replication forks. During replication, when Pol $\delta$ stalls at a DNA lesion, PCNA gets ubiquitinated by $\operatorname{Rad} 6 / \operatorname{Rad} 18$. Mono-ubiquitinated PCNA activates the mutagenic pathway where, for translesion synthesis to occur, Pol3 is removed from the stalled Pol $\delta$ complex by a Def1-dependent manner through proteasome-mediated protein degradation. We assume that a mutagenic TLS polymerase takes over the

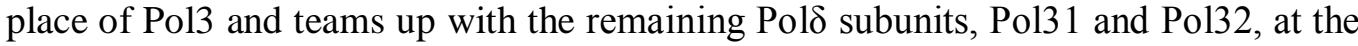
stalled fork to form a new complex capable of executing DNA lesion bypass.

We surmise that after lesion bypass and deubiquitination of PCNA, the TLS polymerase is removed from the primer terminus, Pol3 restores Pol $\delta$ by regaining its place, and replication continues. Importantly, this finding also gives an explanation for previous genetic results showing that in pol32 cells induced mutagenesis is severely impaired.

Our data raises an interesting question: how the RAD30-encoded TLS polymerase, Pol $\eta$ can operate independently of Def1? Our results imply that Pol3 does not have to be removed from the stalled fork for Poln-dependent UV-lesion bypass to occur. Pol $\eta$ is mainly specialized for the error-free bypass of cyclobutane pyrimidine dimers formed upon UV irradiation. Since UV is one of the most common DNA damage sources most living things are exposed to, it is reasonable to assume that Poln should have preference over the other error-prone TLS polymerases in the bypass of UV-induced DNA lesions.

Poln, a Y family polymerase, differs from the other TLS polymerases, Rev1

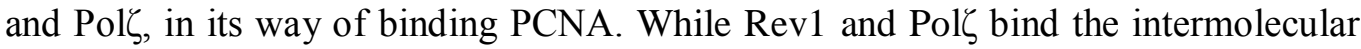


interface at the outer face of the PCNA ring [126, 127], Pol $\eta$, similarly to Pol $\delta$, binds the interdomain connector loop of PCNA through its conserved PCNA-interacting peptide motif. Given, that PCNA is a homotrimer ring, Pol $\delta$ and Pol $\eta$ could bind the same PCNA ring simultaneously.

We presume that transient conformational changes, probably induced by the stalling of the fork and ubiquitilation of PCNA, could allow Poln to take over

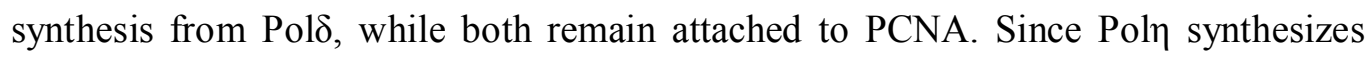
opposite pyrimidine dimers with the same kinetics as it does opposite undamaged DNA, rapid bypass can occur. Deubiquitilation of PCNA would restore the original conformation and Pol $\delta$ could continue synthesis. A similar mechanism has already been described in bacteria.

Many elements of DNA lesion bypass proved to be highly conserved from yeasts to humans. The role of TLS polymerase in mutagenesis and in cancer makes it highly important to identify the human homologue of Def1. 


\section{Summary in Hungarian}

A DNS károsodás következtében elakadt replikációs villa mentése nagy kihívást jelent a sejtek számára, mivel a befejezetlen replikáció illetve a felhalmozott DNS károsodások kromoszóma instabilitáshoz, végső esetben pedig a sejtek halálához vezethet. A sejtek túlélésük érdekében különböző mechanizmusokat fejlesztettek ki, amelyekkel képesek a replikációs villa mentésére. Ezek az úgynevezett DNS-hiba tolerancia útvonalak teszik lehetővé, hogy a DNS-hibák tényleges eltávolítása nélkül a replikáció folytatódhasson tovább. A DNS-hiba tolerancia útvonalnak két fő típusa van: a templátváltás (Template switching) és a transzléziós DNS szintézis (TLS). A templátváltás hibamentes átírást biztosít, mivel templátként az újonnan létrejövő DNS szálat használja. Ezzel szemben a transzléziós szintézis során speciális polimerázok veszik át a replikatív polimeráz helyét, és a DNS-hibával szemben hibamentesen a megfelelő vagy hibásan egy másik bázist épít be.

A Rad6-Rad18 kulcsfontosságú szereplői a DNS-hiba tolerancia útvonalnak Saccharomyces cerevisiae élesztőben. Ezek a fehérjék három alútvonalon keresztül szabályozzák az UV-károsodást szenvedett DNS replikációját: 1. a Rad5-függő hibamentes átírás, 2. Rad30-függő hibamentes átírás, 3. Rev3-függő hibát generáló átírás. Ismert, hogy UV kezelés hatására a Rad6-Rad18 ubikvitin konjugáló és ligáz enzimkomplex monoubikvitinálja a PCNA-t a 164-es lizinén. A monoubikvitinált PCNA aktiválja a Rev3 illetve a Rad30 függő transzléziós DNS szintézist. Más esetekben azonban további faktorok, mint az Mms2/Ubc13 ubikvitin konjugáló és Rad5 ubikvitin ligáz enzimek poliubikvitinálják a PCNA-t és aktiválják a Rad5 alútvonalat.

Laborunkban azonosítottuk a DEF1-et, mint a RAD6-RAD18 DNS-hiba tolerancia útvonal Rev3-függő ágának tagját és az élesztő mutagenezis egyik szabályozóját. A Rev3 útvonalban szereplő TLS polimerázok átveszik a replikatív polimeráz helyét, amely fontos lépés, de csak kevéssé ismert része a teljes mechanizmusnak. Mivel a Def1 nem polimeráz, ellentétben a Rev3 útvonal többi tagjával, ezért feltételeztük, hogy a TLS- és a replikatív polimerázok közötti cserében játszik szerepet hiba átirása során.

Munkánk során bizonyságot nyert, hogy a Def1 kulcsfontosságú szereplő a

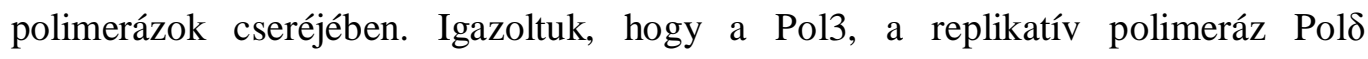
katalítikus alegysége lebomlik UV kezelés hatására. Kimutattuk, hogy a Pol3 
lebomlása poliubikvitináció függő proteoszómális degradáció eredménye, amely a Def1 szabályozása alatt áll. Ezzel szemben a Pol31 és a Pol32, a Pol $\delta$ másik két alegysége nem degradálódik. Azt is kimutattuk, hogy Pol31 és Pol32 együttesen stabil komplexet képezhetnek a Rev1 TLS polimerázzal.

Kutatási eredményeink alapján új modellt állítottunk fel. A DNS károsodás következtében elakadt replikációs villánál a Rad6-Rad18 fehérjék monoubikvitinálják a PCNA-t. A monoubikvitinált PCNA aktiválja a mutagén útvonalat, ahol a Def1 közremüködésével a Pol $\delta$ replikatív polimeráz komplexből a Pol3 poliubikvitin szignálnak köszönhetően proteaszómális degradációra kerül. Így a Pol3 helyét egy mutagén TLS polimeráz veszi át, amely a Pol31és Pol32 alegységekkel komplexet képezve írja át a hibás szakaszt. Miután a sérült szakasz átírásra került, a TLS polimeráz ledisszociál, a Pol3 ismét kötődik a replikatív polimeráz alegységeként, így a replikáció pedig folytatódhat tovább.

További kérdés maradt azonban: Hogyan müködhet DEFl-től függetlenül a RAD30 által kódolt Poln TLS polimeráz? Kísérleteink azt mutatják, hogy a Pol3-t ebben az esetben nem kell eltávolítani az elakadt villáról. A Poln elsősorban az UVkárosodás következtében kialakuló ciklobután pirimidin dimerek hibamenetes javítására specializálódott. Mivel az UV az egyik leggyakoribb DNS károsító hatás az élőlényekre nézve, ezért úgy gondoljuk, hogy a Poln előnyt kell, hogy élvezzen a TLS polimerázok kiválasztásánál DNS hibaátírás sorrán.

A Pol $\eta$ a polimerázok Y családjának egy tagja, amely a Rev1 és Pol $\zeta$ TLS

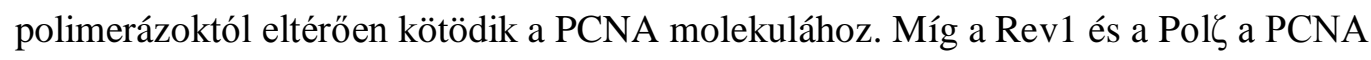

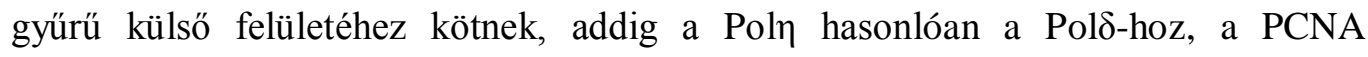
intermolekuláris hurok doménjéhez kötödik. Ez lehetővé teszi, hogy a PCNA trimerhez egyszerre mind a két polimeráz kapcsolódjon. Feltételezzük, hogy az elakadt replikációs villánál a PCNA monoubikvitinálásának hatására olyan konformációs változás zajlik le, aminek során a PCNA-hez kötődött Pol $\eta$ átveszi a szintézist a Pol $\delta$-tól. Elvégezve az átírást, a PCNA deubikvitinálása visszaállítja a

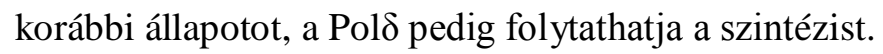

Bizonyosságot nyert, hogy a DNS-hiba tolerancia útvonal több eleme erős konzerváltságot mutat élesztő és az ember között. Ezért úgy gondoljuk, hogy kutatási eredményünk hozzájárul az emberi mutagenezis folyamatának megértéséhez is. 